\title{
LIPID PRODUCTIVITY OF ALGAE GROWN ON DAIRY WASTEWATER AS A POSSIBLE FEEDSTOCK FOR BIODIESEL
}

A Master's Thesis Presented to the Faculty California Polytechnic University, San Luis Obispo

In Partial Fulfillment

of the Requirements for the Degree

Master of Science in

Civil and Environmental Engineering

by

Ian Charles Woertz

December 2007 


\section{AUTHORIZATION FOR REPRODUCTION OF MASTER'S THESIS}

I grant permission for the reproduction of this thesis in its entirety or any parts, without further authorization from me, provided the author and major advisor are properly referenced.

Signature

Date 


\section{APPROVAL PAGE}

LIPID PRODUCTIVITY OF ALGAE GROWN ON DAIRY WASTEWATER AS A POSSIBLE FEEDSTOCK FOR BIODIESEL

IAN WOERTZ

SUBMITTED:

Committee Chair: Yarrow Nelson, Ph.D.

Date

Committee Member: Tryg Lundquist, Ph.D.

Date

Committee Member: Andrew Kean, Ph.D.

Date 


\begin{abstract}
Lipid Productivity of Algae Grown on Dairy Wastewater as a Possible Feedstock for
\end{abstract} Biodiesel

Ian Woertz

The objective of this thesis is to develop a biological wastewater treatment system that utilizes algal growth to simultaneously create renewable energy in the form of biodiesel and digester biogas, remove polluting nutrients, and abate greenhouse gases. Research under the Department of Energy Aquatic Species Program during 1978-1996 concluded that cultivating algae for biofuels was cost prohibitive at that time and that an integrated approach should be studied that combined wastewater treatment with algal biofuel production. Nutrient removal, in particular nitrogen and phosphorus, from wastewater is a growing regulatory need and the use of algae cultivation could create a unique marriage between waste treatment and biofuel production. To investigate this possible synergy, bench-scale tests were conducted to determine potential algal lipid productivity with mixed-cultures of algae grown on anaerobically-pretreated dairy wastewater in batch mode. The total lipid content of the algae ranged from $8 \%$ to $29 \%$ of algal mass. Maximum biomass concentration reached $920 \mathrm{mg} / \mathrm{L}$, measured as volatile suspended solids, on Day 13 of incubation. In contrast, maximum total lipid content was reached at Day 6 , corresponding to a lipid productivity of $2.8 \mathrm{~g} / \mathrm{m}^{2} /$ day, or 1,200 gallons/acre/year if scaled up. Nutrient removal over 12 days of incubation was nearly complete. Total ammonia $\left(\mathrm{NH}_{3}+\mathrm{NH}_{4}{ }^{+}\right)$was reduced $96 \%$ to $1.1 \mathrm{mg} / \mathrm{L}$ as $\mathrm{N}$, and phosphate $\left(\mathrm{PO}_{4}{ }^{3-}\right)$ was reduced $>99 \%$ from an initial concentration of $2.5 \mathrm{mg} / \mathrm{L} \mathrm{PO}_{4}$ as $\mathrm{P}$. 


\section{ACKNOWLEDGMENTS}

I would like to thank my thesis advisors for their support during the work of this thesis. I would like to thank Dr. Yarrow Nelson for his inspiration, dedication and friendship throughout the creation of this master's thesis. Without Dr. Nelson I would not have made it through the many late hours of experimentation and the countless drafts that it took to get to this point. I would also like to thank Dr. Tryg Lundquist who made this project possible with his endless knowledge of algae and wastewater. I feel incredibly fortunate to have met someone as talented and passionate about algae as Dr. Lundquist and I look forward to what the future of algae-biofuels will bring. In addition, I would like to thank Dr. Andrew Kean for his support during all the presentations that led up to my defense as well as his contribution in editing this thesis.

I would like to thank my co-workers and friends here at Cal Poly: Adam Feffer and Kyle Poole for their analytical support and endless laughs in lab, Laleh Rastegarzadeh for her enthusiasm and support in DC, and the rest of my friends here at school that always believed in me.

And finally, I would like to thank my family for their love and sacrifice throughout my college career and better part of two decades of education.

Joint funding for this project was provided by the U.S. Environmental Protection Agency's People, Prosperity, and Planet (P3) student competition and the U.S. Department of Energy's Small Business Innovative Research (SBIR) Program. 


\section{TABLE OF CONTENTS}

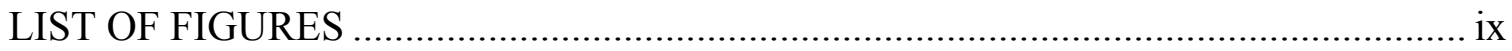

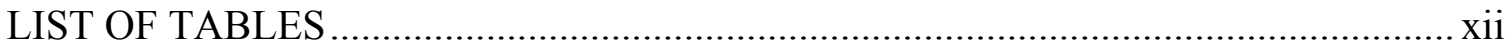

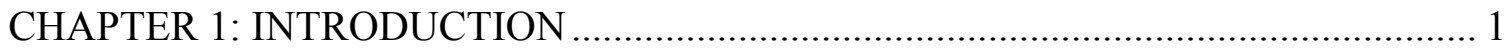

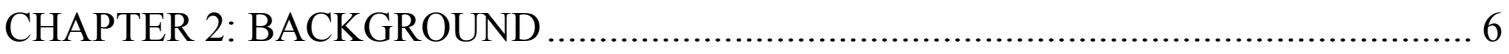

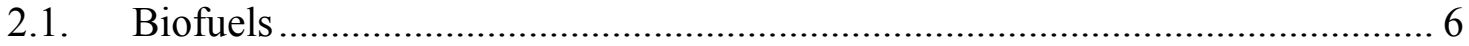

2.1.1. Renewable Energy ............................................................................

2.1.2. Biodiesel and the Feedstock Dilemma.....................................................

2.2. Algae to Biodiesel History ........................................................................ 12

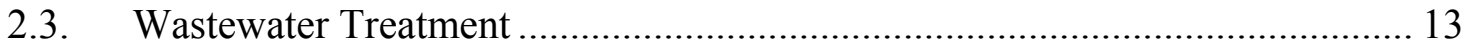

2.3.1. Algae-Based Wastewater Treatment vs. Traditional Methods ....................13

2.3.2. Anaerobic Digestion and Biogas Production...........................................15

2.4. Other Algae Products and Commercial Algae Production .............................. 16

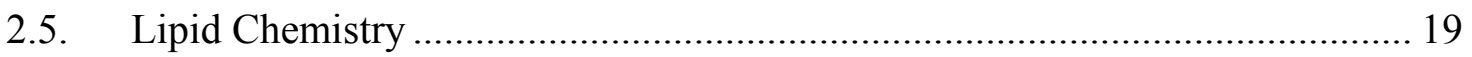

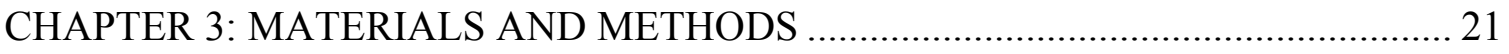

3.1. Collection and Pretreatment of Dairy Wastewater .......................................... 21

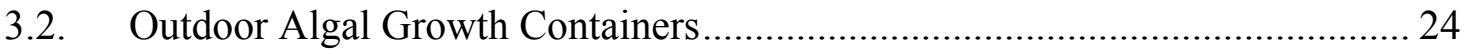

3.2.1. Operation of Initial Semi-Continuous experiments ....................................26

3.2.2. Batch Experiment ..........................................................................28

3.3. Operating Conditions and Additional Testing ............................................... 29

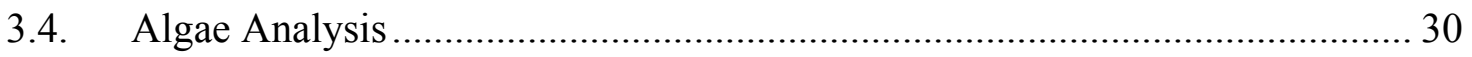

3.4.1. Algae Identification …………………….............................................

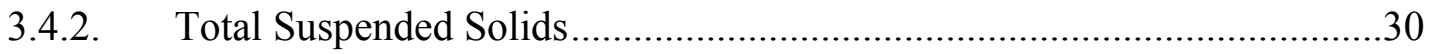




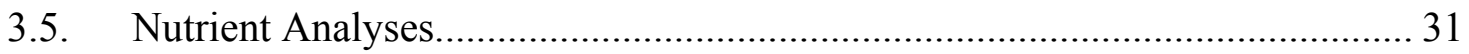

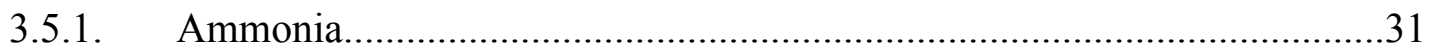

3.5.2. Total Kjeldahl Nitrogen .........................................................................

3.5.3. Nitrate, Nitrite, and Phosphate by Ion Chromatography ...........................32

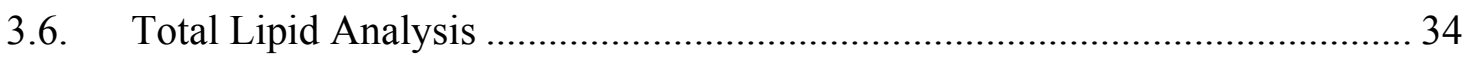

3.7. Dissolved Oxygen Measurement ................................................................. 38

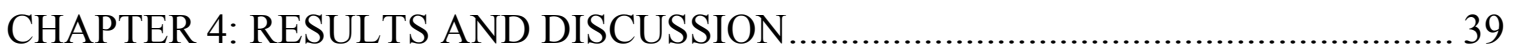

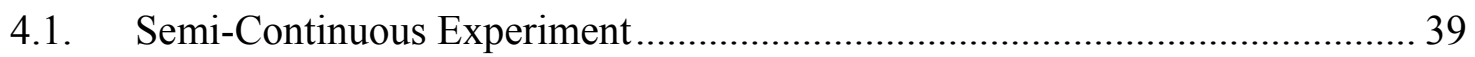

4.1.1. Biomass Results for Semi-Continuous Experiment......................................39

4.1.2. Biochemical Oxygen Demand during Semi-Continuous Experiment.......40

4.1.3. Nutrient Removal Semi-Continuous Experiment .......................................41

4.1.4. Initial Total Lipid Content during the Semi-Continuous Experiment ......44

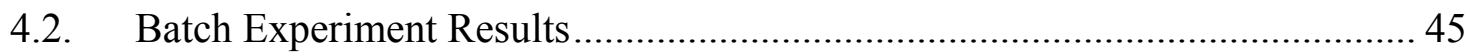

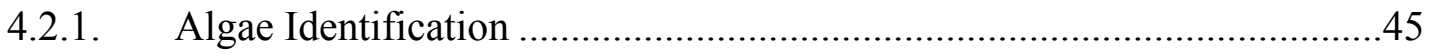

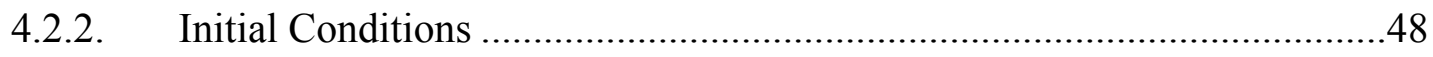

4.2.3. Biomass Results for Batch Experiments and Growth Curves ....................49

4.2.4. Total Lipid Percentages and Productivity .................................................52

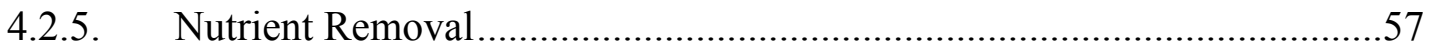

4.2.6. Dissolved Oxygen and $\mathrm{pH}$ Changes During Batch Experiments...............61

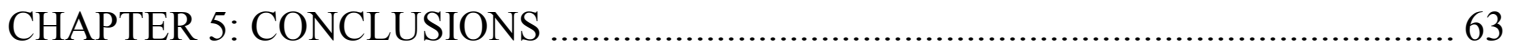

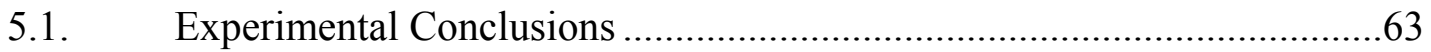

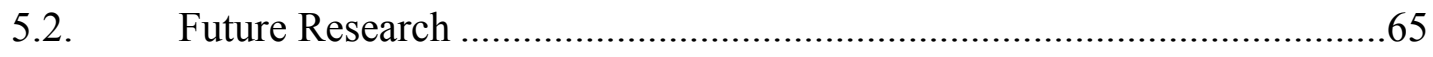

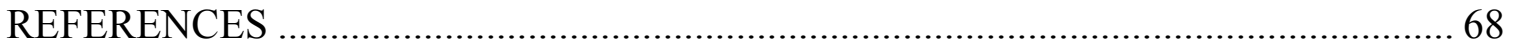




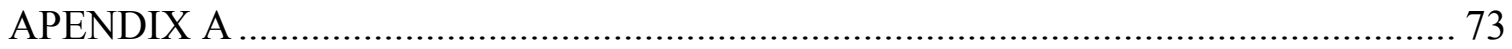

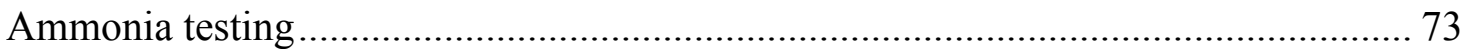

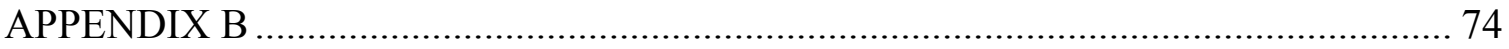

Kjeldahl Nitrogen Testing...................................................................................... 74

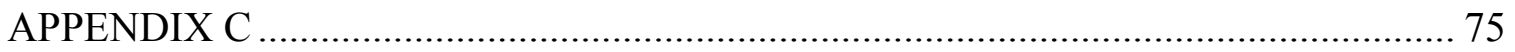

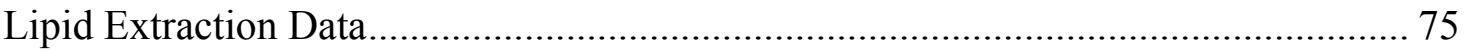




\section{LIST OF FIGURES}

Figure 1.1 Combined dairy wastewater treatment and algae-biodiesel feedstock

production

Figure 2.1: US energy use sector breakdown, 2005 (EIA, 2005) …………………....... 7

Figure 2.2: U.S. renewable energy as share of total energy, (EIA, 2005) …………….... 8

Figure 2.3: U. S. Transportation sector energy consumption (EIA, 2005) ......................... 9

Figure 2.4: Algae-bacteria symbiosis in wastewater treatment (Lundquist, 2007) .......... 14

Figure 2.5: High rate ponds for Spirulina ……………......................................... 18

Figure 2.6: Paddle wheel mixer in HRP for wastewater treatment Hilmar,

California (photo credit: T. Lundquist).......................................................18

Figure 3.1: Cal Poly Dairy, San Luis Obispo with ........................................................ 21

Figure 3.2: Wedge wire sloped screen at the Cal Poly Dairy........................................ 22

Figure 3.3: Anaerobic digester.............................................................................. 23

Figure 3.4: Algae bioreactors (and anaerobic digester in background) ........................... 25

Figure 3.5: Diagram of an algae bioreactor. ……………........................................... 25

Figure 3.6 Algae bioreactor with air mixing and $\mathrm{CO} 2$ sparging ...................................... 26

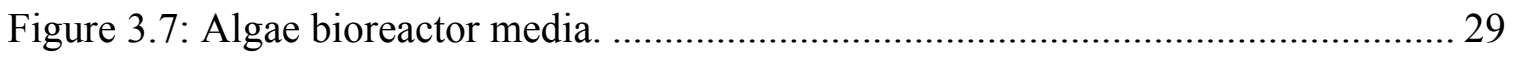

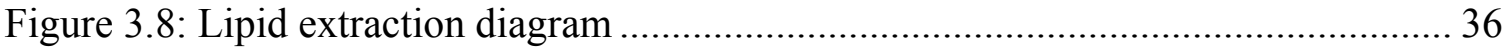

Figure 3.9: Fume hood with lipid extraction equipment.................................................... 37

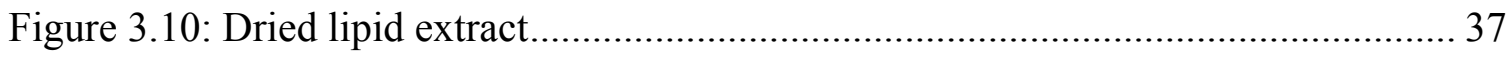


Figure 4.1: Biomass and $\mathrm{pH}$ for semi-continuous experiment for $\mathrm{R} 1$ tank. 40

Figure 4.2: Nitrite concentrations during the semi-continuous experiment. 42

Figure 4.3: Nitrate removal during the semi-continuous experiment. 43

Figure 4.4: Phosphate removal during the semi-continuous experiment. 44

Figure 4.5: Photomicrograph of Scenedesmus at 1000x (phase contrast) at Day 45 of the semi-continuous experiment R5. .46

Figure 4.6: Photomicrograph of Micractinium at 100x (phase contrast) on Day 45 of the semi-continuous experiment R5. .46

Figure 4.7: Photomicrograph of Actinastrum at 1000x (phase contrast) on Day 27 of the semi-continuous experiment $\mathrm{R} 1$.

Figure 4.8: Photomicrograph of flocculated Scenedesmus at 400x (Dark Phase) on Day 45 of the semi-continuous experiment $\mathrm{R} 4$ .48

Figure 4.9 Biomass and $\mathrm{pH}$ for batch experiment for $25 \% \mathrm{WW}$ dilution. 50

Figure 4.10 Biomass and $\mathrm{pH}$ for batch experiment for $25 \% \mathrm{WW}$ dilution. 51

Figure 4.11 Log phase of biomass for $25 \% \mathrm{WW}$ dilution algae growth reactor 51

Figure 4.12 Log phase of biomass for $10 \% \mathrm{WW}$ dilution algae growth reactor 52

Figure 4.13: 25\% WW Dilution algae growth and lipid content during batch run. 54

Figure 4.14: 10\% WW Dilution algae growth and lipid content during batch run. 55

Figure 4.15: Nutrient reduction in $25 \%$ dilution culture. 58

Figure 4.16: Nutrient reduction in $10 \%$ dilution culture. 59

Figure 4.17: Dissolved oxygen and $\mathrm{pH}$ change in $25 \%$ dilution culture through sunrise on March $24^{\text {th }}, 2007$ 
Figure 4.18: Dissolved oxygen and $\mathrm{pH}$ change in $10 \%$ dilution culture through sunrise March $24^{\text {th }}, 2007$. 


\section{LIST OF TABLES}

Table 4.1: Lipid percentage in biomass during semi-continuous experiment ................ 45

Table 4.2: Initial characteristics of diluted dairy wastewater. ................................... 49

Table 4.3: Lipid productivity of algae reported in the literature...................................56

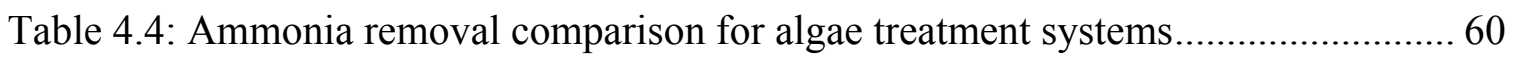

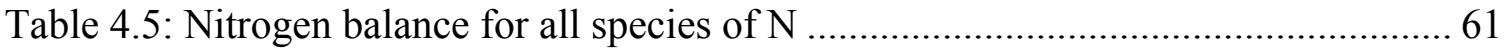




\section{CHAPTER 1: INTRODUCTION}

"We, the human species, are confronting a planetary emergency — a threat to the survival of our civilization (climate change) that is gathering ominous and destructive potential even as we gather here. But there is hopeful news as well: we have the ability to solve this crisis and avoid the worst — though not all — of its consequences, if we act boldly, decisively and quickly" (Al Gore, acceptance speech for the Nobel Peace Prize, 2007). Global atmospheric concentrations of carbon dioxide, methane and nitrous oxide have increased markedly as a result of human activities since 1750 and now far exceed pre-industrial industrial values (IPCC, 2007). The global increase in carbon dioxide concentration is due primarily to fossil fuel use and land use change, while those of methane and nitrous oxide are primarily due to agriculture (IPCC, 2007). With these concerns of pollution, global warming, and energy shortages society is beginning to look to biofuels as a replacement energy source.

Biofuels produced from plants have the potential to replace a portion of our fossil fuel consumption with a renewable alternative. However, there is growing concern that the use of food crops for biodiesel and other renewable fuels may be an uneconomical long term solution (Patzek and Pimentel, 2005). Previous research in the early 1990's by the National Renewable Energy Laboratory (NREL) showed that under controlled conditions algae are capable of producing 40 times the amount of oil for biodiesel per unit area of land, compared to terrestrial oilseed crops such as soy and canola (Sheehan et al., 1998). However, their results also showed that large-scale algae cultivation for energy production was uneconomical at that time and suggested future research into waste- 
stream integration (Sheehan et al., 1998). It is hoped that the economics will be ultimately improved by combining biodiesel feedstock production with agricultural or municipal wastewater treatment and $\mathrm{CO}_{2}$ fixation. The research presented here was conducted to determine the feasibility of producing biodiesel feedstock in the form of microalgae grown in dairy wastewater ponds as one approach to waste-stream integration. Further, the rapidly increasing price of petroleum and weakening US dollar are improving the economic feasibility of alternative fuels since the conclusion of the NREL study.

Biodiesel production from algae grown in dairy wastewater has the potential to address three important societal needs: Development of new energy sources, management of agricultural wastes to protect aquatic environments and reduction of the global anthropogenic greenhouse effect. Due to dwindling domestic petroleum reserves and dependence on foreign oil from unstable regions it is imperative for the U.S. to develop new domestic energy sources. Biodiesel production is one possible route to supplement our energy production (Tickell, 2006). Agricultural waste is also becoming recognized as an important environmental problem as the use of high-capacity confined animal farming and intensive plant farming increases. Of particular concern is nutrient run-off from manure and chemical fertilizer, which contributes to eutrophication and hypoxia of receiving water bodies (NRC, 2007). Algal treatment ponds have the potential to reduce nitrogen and phosphorus nutrients through assimilation into algal biomass followed by biomass harvesting. The third issue, global warming, as stated before, is important because atmospheric concentrations of carbon dioxide, methane and nitrous oxide are 
increasing (IPCC, 2007). Biomass energy sources can be carbon neutral, meaning that the $\mathrm{CO}_{2}$ that is emitted during combustion of the biofuel will be absorbed into the next crop of plants that are grown as biofuel feedstock, thus creating a closed carbon cycle. Algae feedstock production on wastewater is likely to have a much more beneficial carbon balance than feedstock produced with chemical fertilizers, which require fossil fuel in their manufacture. In addition, the use of chemical fertilizers, such as nitrogen and phosphorus, have significant costs associated with them which are avoided through the combination of wastewater acting as the fertilizer.

The goal of this research is to contribute to the development of an integrated algae biofuel and wastewater treatment process. This process would simultaneously create algae feedstock for biogas or biodiesel and remove nutrients from dairy lagoon wastewater. Algae production and nutrient removal would be accelerated by addition of $\mathrm{CO}_{2}$ from digester gas combustion in a boiler or generator. There was a companion study performed by fellow graduate student Adam Feffer examining the effects of $\mathrm{CO}_{2}$ addition on algae based municipal wastewater treatment (Feffer, 2007).

The ultimate vision for the proposed integrated algae-based treatment production process is shown in Figure 1.1. Wastewater is first screened and transferred to an anaerobic digester. The anaerobic digester breaks down organic carbon into methane gas which can be used as an energy source in a biogas generator. The effluent from the anaerobic digester, which remains rich in nutrients, is then transferred to algae ponds. Exhaust gas from the generator, rich in $\mathrm{CO}_{2}$, is sparged into the algae ponds. The $\mathrm{CO}_{2}$ sparging 
accelerates the treatment and algal growth, balances the high nitrogen in the wastewater with carbon, and fixes the $\mathrm{CO}_{2}$ in the algal biomass, which abates greenhouse gas releases once the algae biofuel is used. The algae are then harvested, and the lipids are extracted and converted into biodiesel. The residual algal biomass after lipid extraction can also be used as a fertilizer for crop production.

The purpose of the research described in this thesis is to determine the direct feasibility of producing biodiesel from algae grown on agricultural wastewater for simultaneous energy production and nutrient removal. The specific objectives include:

1. Operate bench-scale algal growth ponds to determine the feasibility of producing lipids from algae grown from dairy wastewater.

2. Determine growth rates and lipid content of mixed algae cultures grown in dairy wastewater.

3. Determine the efficiency of nutrient removal from dairy wastewater using benchscale algae ponds. 


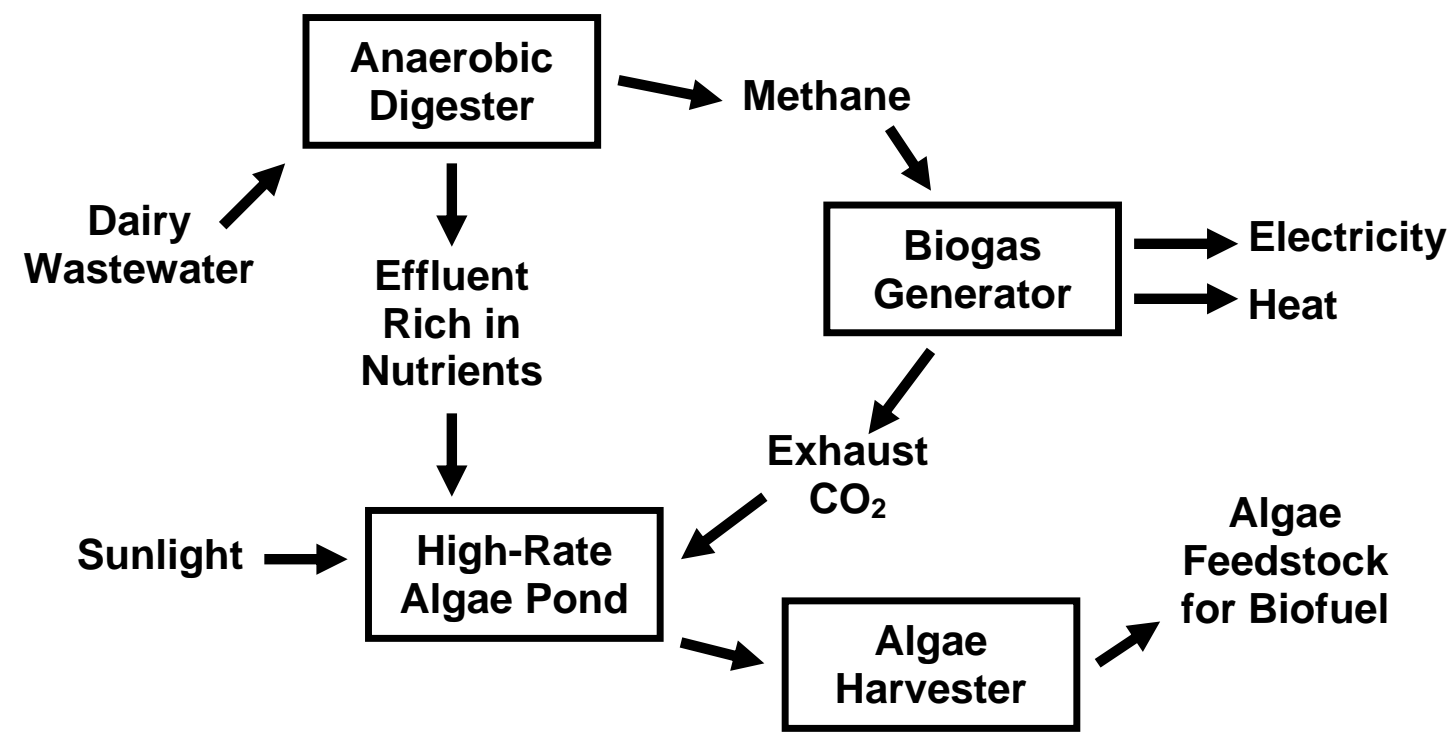

Figure 1.1 Combined dairy wastewater treatment and algae-biodiesel feedstock production 


\section{CHAPTER 2: BACKGROUND}

This section gives a breakdown of U.S. energy use with discussion of the U.S. biodiesel feedstock outlook, a review of at wastewater treatment methods with emphasis on algaebased systems, anaerobic digestion/ biogas production, algae products and production, and lipid chemistry.

\subsection{Biofuels}

\subsubsection{Renewable Energy}

To understand the impact that biofuels can have in the U.S. we will first discuss where energy is used by sector, the sources of that energy, and the trends in liquid fuel consumption. The energy consumed in the U.S. is split between residential, commercial, industrial, and transportation uses (Figure 2.1). Our residential and commercial sectors combined consume $40 \%$ of our total energy. Our industrial processes consume $32 \%$ of our total energy and our transportation consumes $28 \%$ of the total energy consumption. 


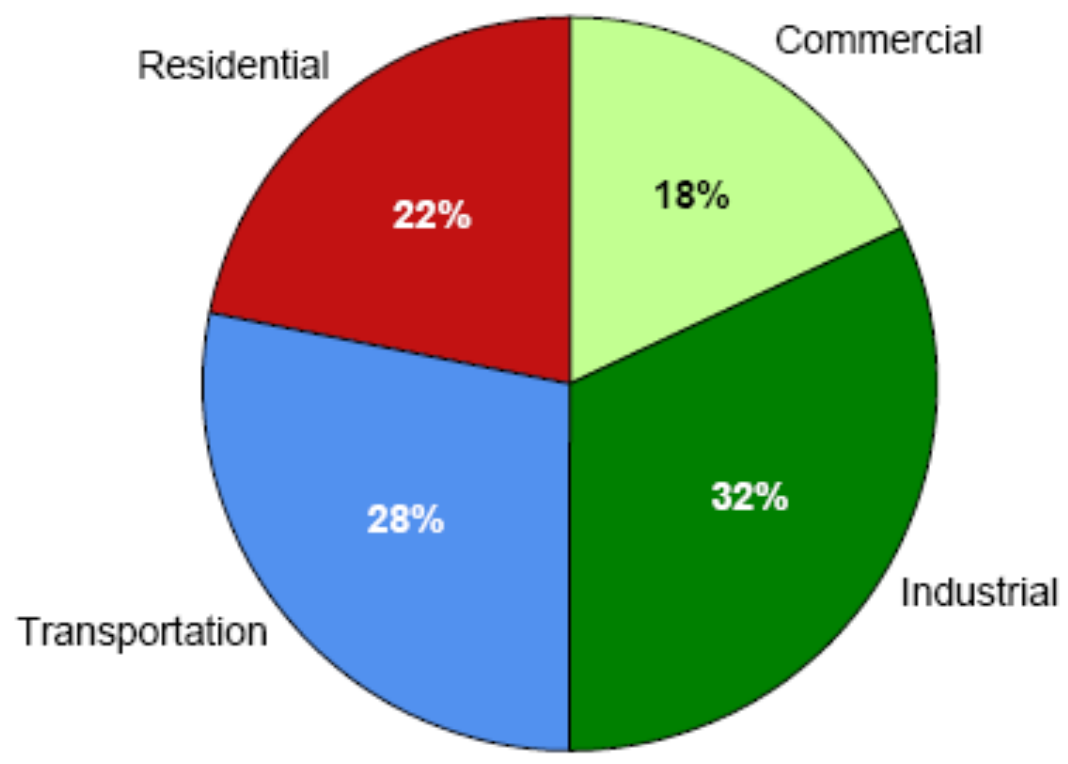

Figure 2.1: US energy use sector breakdown, 2005 (EIA, 2005)

Our breakdown of current sources of energy in the U.S. is shown in Figure 2.2.

Renewable energy contributes only $6 \%$ of our total energy production (EIA, 2005). The largest portion of our energy is produced from petroleum at $40 \%$ followed by natural gas, coal and nuclear power (Figure 2.2). Of the total amount of renewable energy produced, the largest portion (45\%) comes from hydroelectric power and only $6 \%$ comes from alcohol fuels for transportation (Figure 2.2). The amount of energy produced from biodiesel is so small it is not even included in the breakdown. 


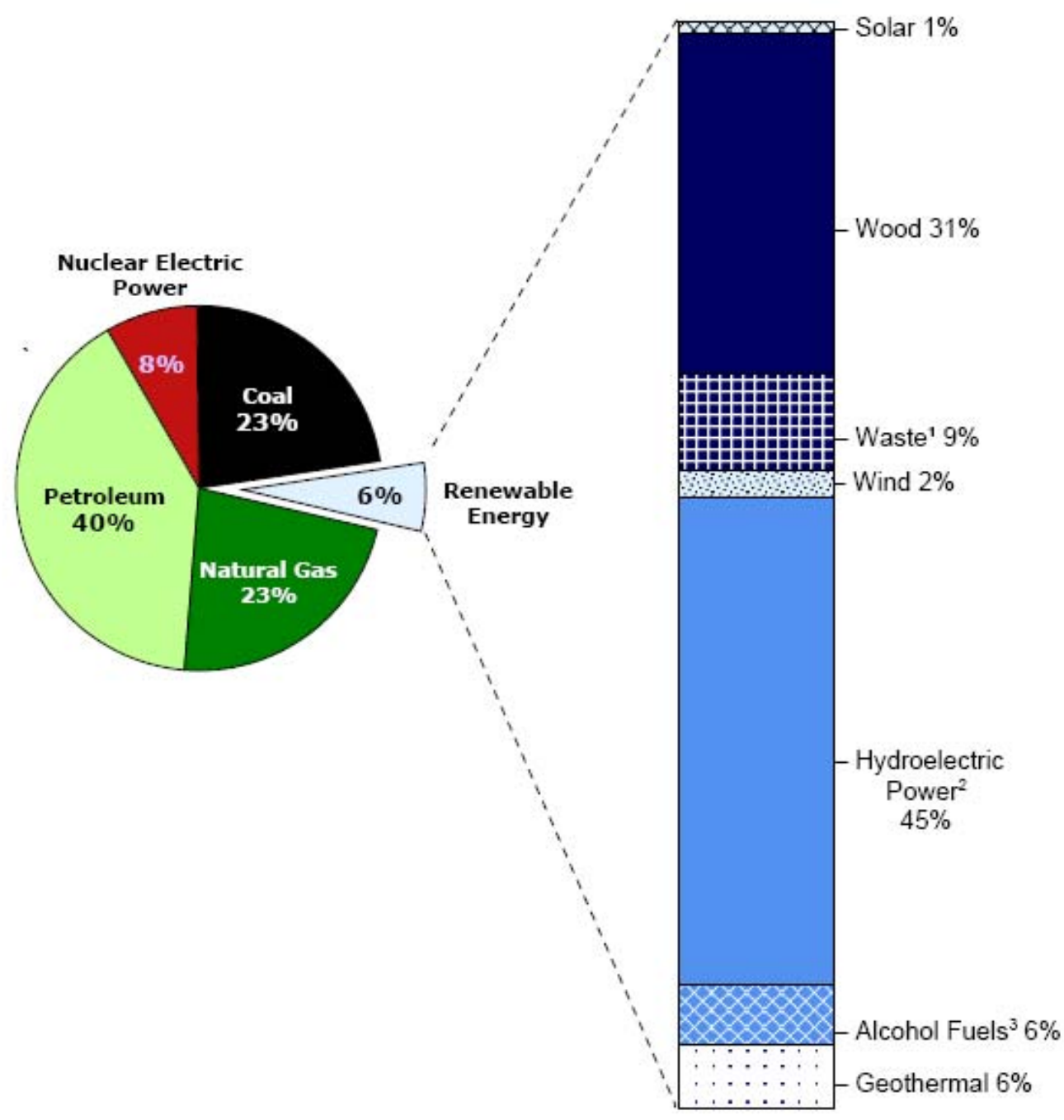

Figure 2.2: U.S. renewable energy as share of total energy, (EIA, 2005)

${ }^{1}$ Municipal solid waste, landfill gas, tires, agricultural byproducts, and other biomass

${ }^{2}$ Conventional hydroelectric power 
Over three times as much motor gasoline is consumed compared to middle distillate fuel such as diesel (EIA, 2005). Over 9 million barrels of gasoline and less than three million barrels of distillate fuel are consumed every day. Both of these numbers have been steadily increasing for the past 50 years (Figure 2.3).

$$
12-
$$

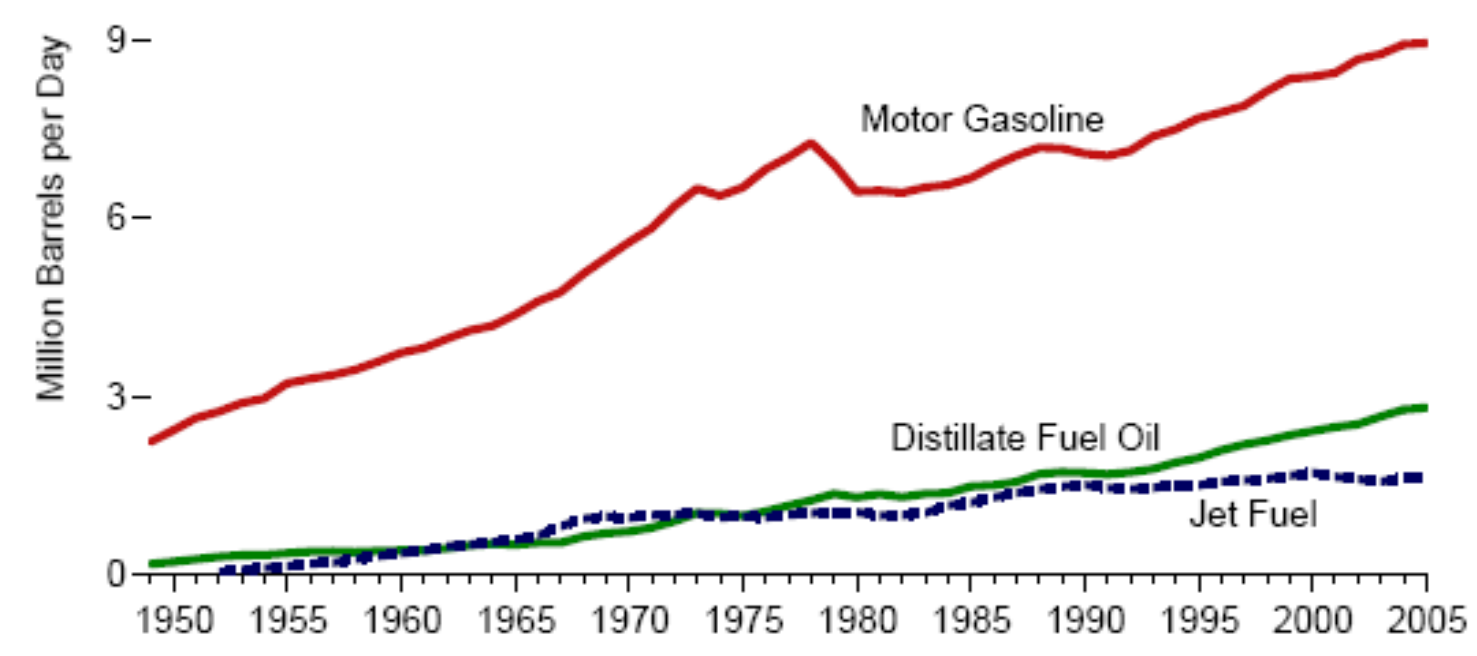

Figure 2.3: U. S. Transportation sector energy consumption (EIA, 2005)

\subsubsection{Biodiesel and the Feedstock Dilemma}

Biodiesel is a fuel that is derived from lipids, which are fatty acids produced from plants or animals. Biodiesel can be used in any diesel engine with little to no modification (National Biodiesel Board, 2007). Compared with petroleum diesel fuel, biodiesel tail pipe emissions of total hydrocarbons, particulates and carbon monoxide are reduced 55\%, $53 \%$, and $48 \%$ respectively (Haas et al., 2001). Biodiesel is also more readily biodegradable than petroleum diesel (Zhang et al., 1998). Total U.S. production of biodiesel in 2006 was over 250 million gallons (USDA, 2006) while manufacturing 
capacity was estimated at close to 600 million gallons annually (National Biodiesel Board, 2007). However, biodiesel production is currently only a small fraction of the estimated 50 billion gallons of distillate fuel and 128 billion gallons of all other transportation fuels that the U.S. consumes annually (EIA, 2005).

As the capacity and demand for biodiesel production increases, so will the demand for an economical feedstock for biodiesel production. The single largest energy cost for production of biofuels is the feedstock (Pimentel and Patzek, 2005). Soy is the most common vegetable oil used due to its availability and high quality of the fuel produced, however, there is increasing interest in alternative feedstocks because of competition with the food industry, which has increased the feedstock cost. Also, the energy intensity of soybean production limits the economic feasibility and energy savings. Some studies have indicated that production of biodiesel from soy and ethanol from corn represents a net energy loss due to energy required for crop production (Patzek and Pimentel, 2005, Talens et al., 2007). However, other studies indicate that there is a modest gain in net energy for biofuels, up to $40 \%$ for corn ethanol and biodiesel (Adler et al., 2007). There are many discrepancies in the reported calculations of net energy production due to variables that change from case to case such as fertilizer source and application, transportation costs for feedstocks, and the value of byproducts from the conversion to biofuels, etc. Further research is needed to calculate the full life cycle emissions and net energy of all fuels, including biofuels. 
Production of biofuel feedstock crops has similar environmental impacts to production of feed and food crops. There is a significant problem with over fertilization in industrial farming and the water runoff causing eutrophication in receiving water bodies as observed in the Gulf of Mexico (NRC, 2007). There are also growing concerns that the industrial farming of corn and soy are causing more pollution than previously thought in the form of air emissions from fertilizers and on-farm nitrogen flows (e.g., $\mathrm{N}_{2} \mathrm{O}$, and $\mathrm{NO}$ ) (Landis et al., 2007).

Soy beans have relatively low oil productivity at 40-50 gallons/acre/year (Pimentel and Patzek, 2005). Canola produces slightly higher oil yields at 100-120 gallons/acre/year, and is being grown mostly in Canada (Pimentel and Patzek, 2005). Palm oil can have productivities up to 636 gallons/acre/year (Chisti et al., 2007). However, there are serious environmental effects being felt in Indonesia due to the enormous export of palm oil to Western Europe for biodiesel production. Land conversion for oil-palm plantations is causing deforestation, leading to long-term soil degradation, loss of precious habitats and extinction of native species in rainforests (Glastra, 2002).

Totaling the current production of crop oil, recycled grease, and animal fat only yields a total of approximately 4.4 billion gallons per year in the U.S. (Duffield USDA, 2007, Tyson NREL, 2002). Assuming all of these oils were diverted to biodiesel it would provide less than $10 \%$ of the 50 billion gallons of diesel fuel consumed annually (EIA, 2005). Therefore it is essential to develop new sources of industrial biomass production for biofuels conversion. 


\subsection{Algae to Biodiesel History}

Microalgae are known to make far more efficient use of solar energy than conventional agriculture (Benemann, 2007) and therefore there is a larger potential for biomass production from algae with less land requirement. Experiments have shown average algae biomass productivities of 30 dry tons/acre/year (Oswald et al., 1957), which is 10 times more productive than wheat (Oswald, 1962). Renewable energy production from algae is not a new concept. Early work was carried out by Golueke et al. (1957) on the anaerobic digestion of algae for producing methane fuel. The most extensive research into the development of biofuels from algae was performed by the National Renewable Energy Laboratory (NREL) from 1978 to 1996 (Sheehan et al. 1998). NREL concluded that a more practical approach for near term production of algae biodiesel is to utilize wastewater treatment for algae propagation (Sheehan et al. 1998), an already well developed technology (Oswald, 2003). Other analyses of full-scale algae to biodiesel production have been conducted by Benemann et al. (1982), Weissman et al. (1987), and more recently Chisti (2007), with differing conclusions. Analysis by Chisti (2007) concludes that the economics of algae-biodiesel will be achievable with improvements to algal biology through genetic and metabolic engineering, and the use of photobioreactors which can provide a controlled environment. However, Benemann (1982) concludes that algae to biodiesel will have a large impact with combination of wastewater treatment in agreement with the NREL study. 


\subsection{Wastewater Treatment}

Municipal and industrial wastewater treatment is a key infrastructural process that keeps our cities, communities and ecosystems sanitary. A great deal of money and effort is spent on the removal of pollutants such as biochemical oxygen demand, turbidity, and nutrients. In addition to these sectors, regulation of farm water pollution is becoming more intense in recent years (California Water Board, 2003). Large confined animal feeding operations such as dairies with over 1,000 head can be major sources of water and air pollution (Centner, 2001). In response, nutrient discharge requirements are being implemented as problems with run-off and ground water contamination becomes more prevalent (California Water Board, 2003).

Nutrients, such as nitrogen and phosphorus, can be removed from wastewater in several ways. The most common way of removing nitrogen is though denitrification leading to reduction of nitrate to nitrogen gas, which is released to the atmosphere (e.g. Metcalf \& Eddy et al., 2003). Phosphorus, on the other hand, is often removed by chemical precipitation using $\mathrm{FeCl}_{3}$, etc. However, both phosphorus and nitrogen can be removed by assimilation. This can be accomplished though the growth of bacteria or algae in the wastewater and then the removal of that biomass. The technique of promoting algae growth for nutrient removal was first developed by Oswald et al., (1957).

\subsubsection{Algae-Based Wastewater Treatment vs. Traditional Methods}

Using algae for wastewater treatment offers some interesting advantages over conventional wastewater treatment. It has been shown to be a more cost effective way to 
remove biochemical oxygen demand, pathogens, phosphorus and nitrogen than activated sludge (Green et al., 1996). Traditional wastewater treatment processes involve the high energy costs of mechanical aeration to provide oxygen to aerobic bacteria to consume the organic compounds in the wastewater. Algae provide an efficient way to consume nutrients and provide the aerobic bacteria with the needed oxygen through photosynthesis (Oswald et al, 1953) (Figure 2.4). Roughly one kg of BOD removed in an activated sludge process requires one $\mathrm{kWh}$ of electricity for aeration, which produces one $\mathrm{kg}$ of fossil $\mathrm{CO}_{2}$ from power generation (Oswald, 2003). By contrast, one $\mathrm{kg}$ of BOD removed by photosynthetic oxygenation requires no energy inputs and produces enough algal biomass to generate methane that can produce one $\mathrm{kWh}$ of electric power (Oswald, 2003).

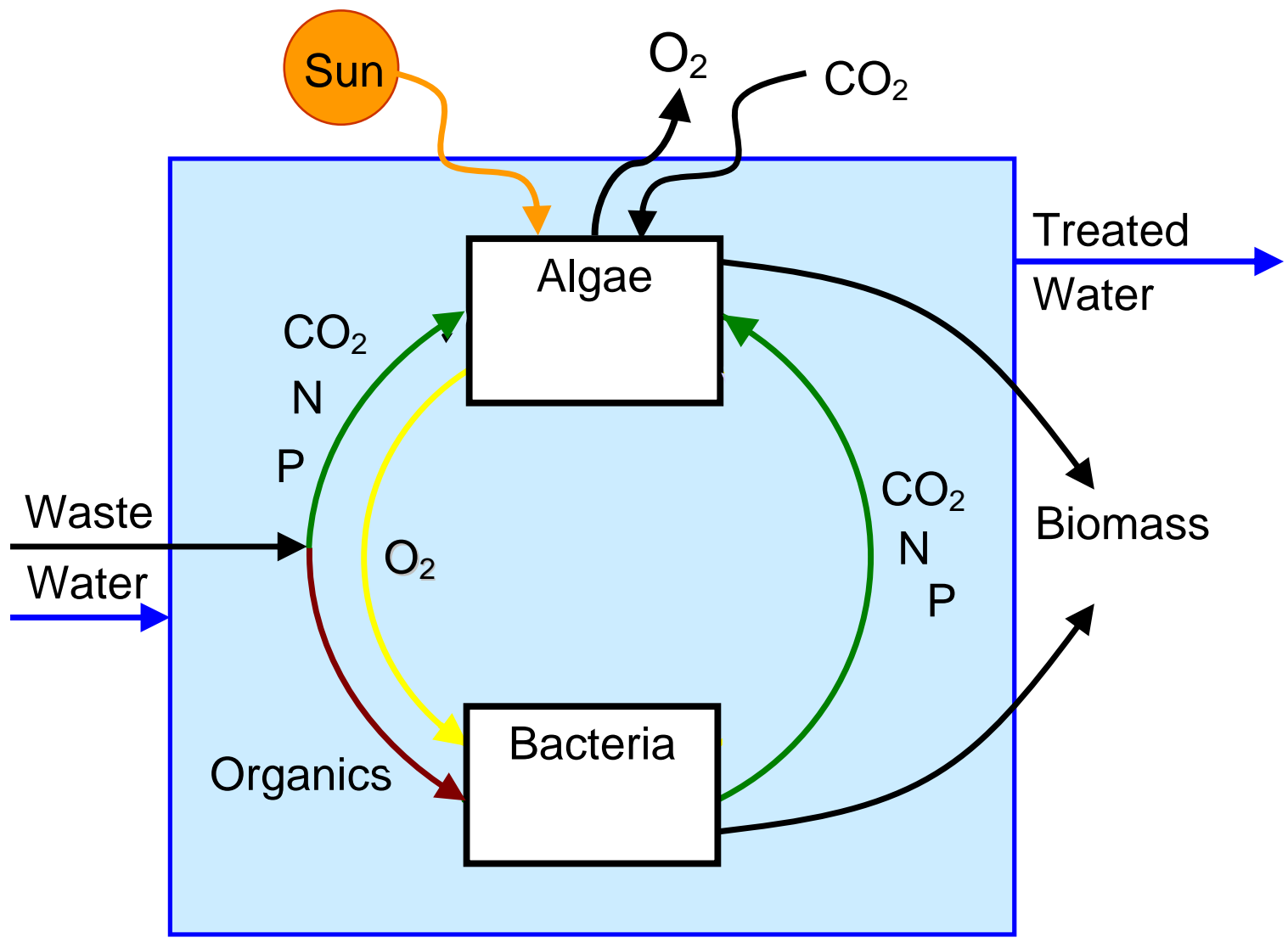

Figure 2.4: Algae-bacteria symbiosis in wastewater treatment (Lundquist, 2007) 
Through the process of algae wastewater treatment very large amounts of algal biomass can be grown. However, it has proven to be difficult to harvest, and even when harvested it is typically not used in a beneficial way (Lundquist et al., 2007). Converting this algal biomass into a higher value energy product in the form of biodiesel is a promising prospect, but there is a need to determine the amount of lipids available from the algae that is grown in wastewater to determine the feasibility of this technology. It will also be important in the future to improve harvesting technology.

\subsubsection{Anaerobic Digestion and Biogas Production}

There are two possible uses for anaerobic digestion and biogas production in combination with algae-based wastewater treatment. One is the use of anaerobic digestion as a pretreatment for the wastewater prior to treatment with algae (which is what was used here in this experiment). This can be an important step because often agricultural wastewaters have very high BOD, which is costly to treat aerobically. The second use is to anaerobically digest the algae biomass produced during treatment. This biomass digestion could provide significant biogas production. Algae digestion is not considered further in this work, however, it is worth noting for future energy output comparisons with algae biodiesel production.

Anaerobic digestion of wastewater is a well-known technology and is widely used in agro-industrial processes such as dairy lagoons. In traditional treatment ponds, wastewater will undergo anaerobic digestion when not properly aerated, releasing 
methane gas, a potent greenhouse gas, into the atmosphere as well as hydrogen sulfide, which has an offensive odor. Creating a controlled anaerobic environment, such as a covered pond or tank, allows the methane to be captured and combusted for energy production. In the biochemical process of anaerobic digestion, the waste goes through three steps as it is converted to methane: hydrolysis, fermentation, and methanogenesis (Metcalf \& Eddy et al., 2003).

Anaerobic digestion is a very effective process for BOD removal, but is not an effective way to remove nutrients (Metcalf \& Eddy et al., 2003). There is thus a need for further treatment of the effluent from anaerobic digesters before it can be discharged into the environment.

\subsection{Other Algae Products and Commercial Algae Production}

Finding uses for algae grown in wastewater has been explored in the past. One of the most valuable products that could be produced would be a protein source for animals. Of course there are many difficulties with this proposal such as prevention of pathogen transmission and contamination with blue-green algae toxins. An observation made by Dugan et al. (1972) was that during the pelletization of algae-barley feed, the heat of the process caused pasteurization of the feed preventing disease transmission from wastegrown algae to animals and later humans. This process may be applied to algae biomass after the oil has been extracted. The algae biomass will still be wet and a heat source is required for drying prior to pelletization. 
Algae biomass can also be used as a fertilizer. This use offers advantages over direct application of nutrient-rich wastewater, which may cause indirect runoff or contamination of ground water. Algae biomass degrades slowly thereby releasing nutrients slowly, which can improve plant uptake (Mulbry et al., 2005), although the timing of nutrient release may not be optimal for some crops.

Currently, over 5,000 dry tons of microalgal biomass are produced annually in the world, mostly in "race way" or "high rate" type ponds (Figure 2.5, and Figure 2.6) for highvalue nutritional supplements (Spolaore et al. 2006). Spirulina is one of the most popular microalgae that is grown for human and animal food and cosmetics, followed by Chlorella and Dunaliella salina (Spolaore et al. 2006). Spirulina, Chlorella and Dunaliella salina have very high protein contents compared to traditional sources of protein (eggs, meat, milk, soybeans, etc.).

Cultures of these algae are kept relatively pure by using culture media that is specific to the organisms (Spolaore et al. 2006). A high bicarbonate concentration allows Spirulina to be grown in open ponds with few invasive algae, and a high saline environment allows Dunaliella salina to be grown in "relative pure cultures" (Anderson, 2005). Producers keep Chlorella cultures somewhat pure by use of large inoculum doses and by operating in short batches with harvesting occurring before major contamination can take place (Benemann, pers. com., 2008). 


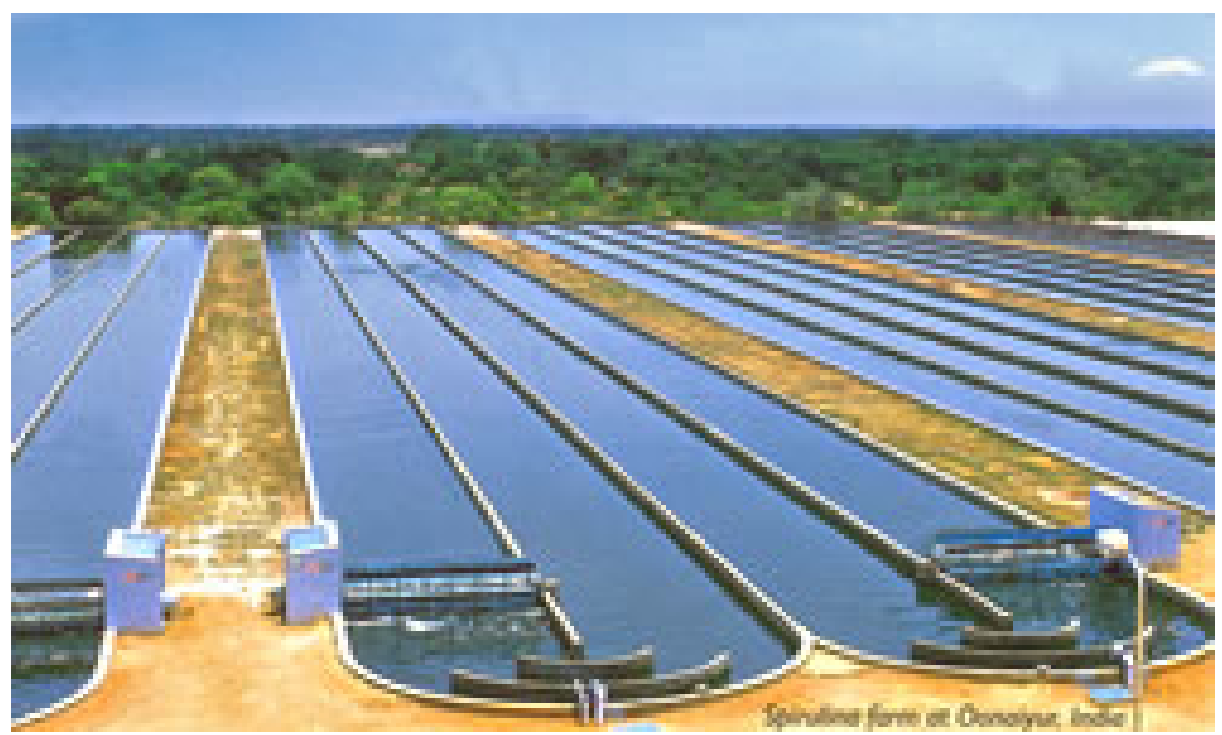

Figure 2.5: High rate ponds for Spirulina production in India (photo credit: Perry Nutriceuticals)

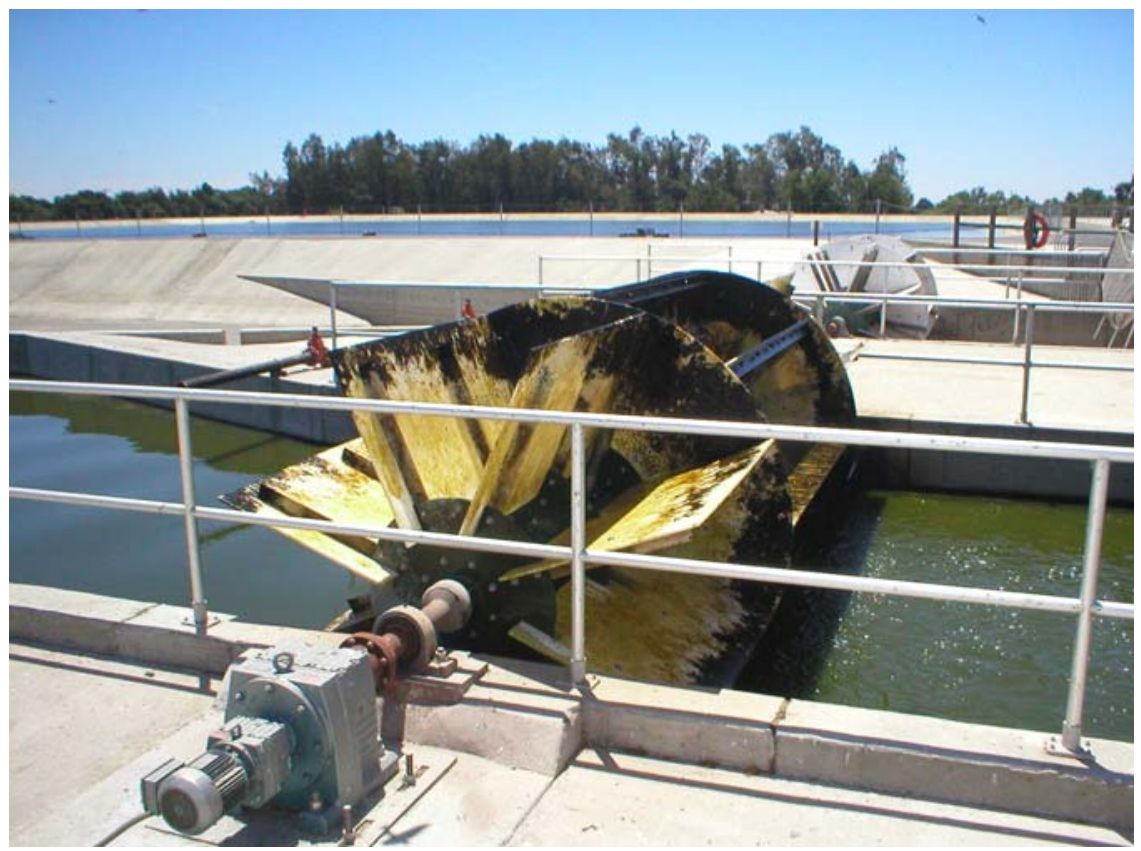

Figure 2.6: Paddle wheel mixer in HRP for wastewater treatment Hilmar, California (photo credit: T. Lundquist)

Algae can also be grown in closed systems allowing single strains of algae to be grown more reliably. There are many different designs of closed system photo-bioreactors that have been researched and used to grow algae (Ono and Cuello, 2004, Wantanabe et al., 2004, Chisti et al., 2001). The products from algae that are grown in the closed 
photobioreactors are specialty food sources as well as pharmaceuticals and pigments. These are closely controlled systems that require costly media inputs.

Due to the popularity and the tremendous recent growth of biofuels use, start-up companies are emerging around the world with the claims of producing biodiesel from algae, most employing some sort of closed-system photobioreactor. However, algae biodiesel has yet to be produced at a commercial scale (Benemann, 2007). It is again important to note that previous studies by the NREL concluded that it would be more economical, at present, to pursue simultaneous wastewater treatment to improve the economics of algae-biodiesel (Sheehan et al., 1998).

Experiments have been conducted that combined the use of wastewater from a piggery as a medium for algae growth for the purpose of producing liquid fuels (An et al., 2003). In that study, the wastewater was first treated with a membrane bioreactor to allow for monoculture of a pure-species of algae. To date, there appears to be no published study on lipid yield from mixed cultures of algae grown on agricultural waste. Lipid percentages for pure cultures of algae are reported in numerous publications, however there has not been any documentation of lipid percentages of mixed cultures of algae that are commonly found in wastewater.

\subsection{Lipid Chemistry}

Lipids are fatty acids and their derivatives, as well as substances related biosynthetically or functionally to these compounds (Christie, 2003). Fatty acids generally contain even 
numbers of carbon atoms in straight chains normally in the range of $\mathrm{C}_{14}$ to $\mathrm{C}_{24}$, with a caroboxyl group at one end. Unsaturated fatty acids occur when there are double bonds of the cis configuration in specific positions. Fatty acids from microalgae have been found to contain combinations of zero to five cis double bonds (Thompson, 1996). Shorthand designation of fatty acids for a saturated chain may look like ' $16: 0$ ', the number before the colon specifying the number of carbon atoms and the number after the colon specifying the number of double bonds. The highly saturated acids are more solid at room temperature. The most typical lipid classes of plant and animal origin consist of fatty acids linked by an ester bond to the trihydric alcohol, glycerol, or to other alcohols such as cholesterol, or by amide bonds to long-chain bases, or on occasion to other amines (Christie, 2003). Lipid type is important to biodiesel production because the quality and variety of lipids will determine the need for pretreatment before it is converted to biodiesel, as well as the final fuel properties. Different processing (i.e. thermal depolymerization) may be required in the case of very poor quality lipids (high free fatty acid content, high degree of unsaturation, etc) to transform the lipids into transportation fuel. It is known that pure cultures of green algae contain primarily $\mathrm{C}_{16}$ $\mathrm{C}_{18}$ fatty acids with a high degree of unsaturation (Thompson, 1996). In the present research, total lipid content rather than lipid type was determined. Lipid type should be determined in future studies as there are no known studies of lipid profiles from mixed cultures grown in wastewater. 


\section{CHAPTER 3: MATERIALS AND METHODS}

\subsection{Collection and Pretreatment of Dairy Wastewater}

The wastewater used in the present study was flush water from the 400-head Cal Poly Dairy. The Cal Poly Dairy facility has a water-based flush system which collects the urine and feces from the free stalls (Figure 3.1). The wastewater is first collected in a settling basin with a 2" x 2" screen to remove any large solids. The effluent from the basin is transferred to a covered sump. The wastewater is then pumped over a wedge wire sloped screen (Figure 3.2), which removes grasses and other fine solids, before being discharged to a large open storage pond. The wastewater undergoes partial treatment while being stored in the pond by aerobic and anaerobic bacteria. The wastewater in this pond is the feed for proposed larger algae ponds and was used for all the bench-scale experiments described below.

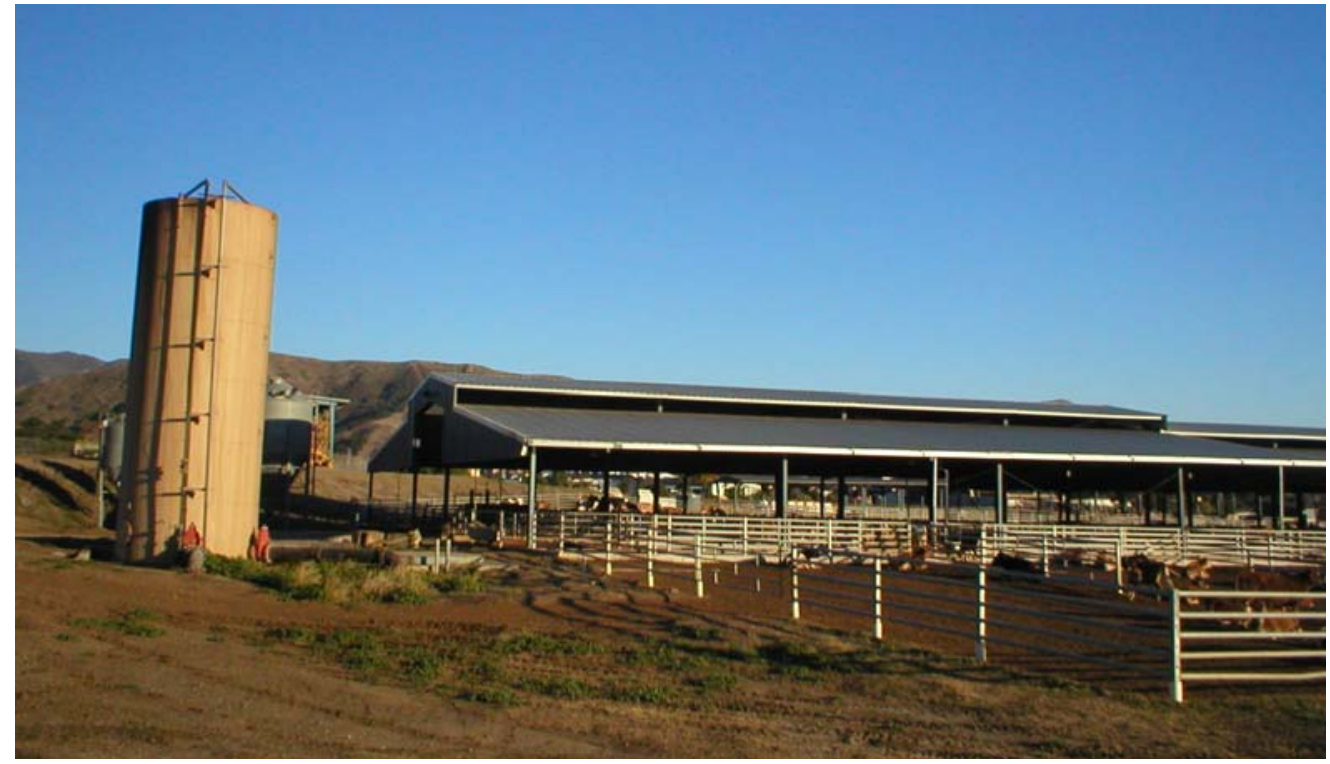

Figure 3.1: Cal Poly Dairy, San Luis Obispo with loafing pens in the foreground and a flush water storage tank and free stall barn in the background. 


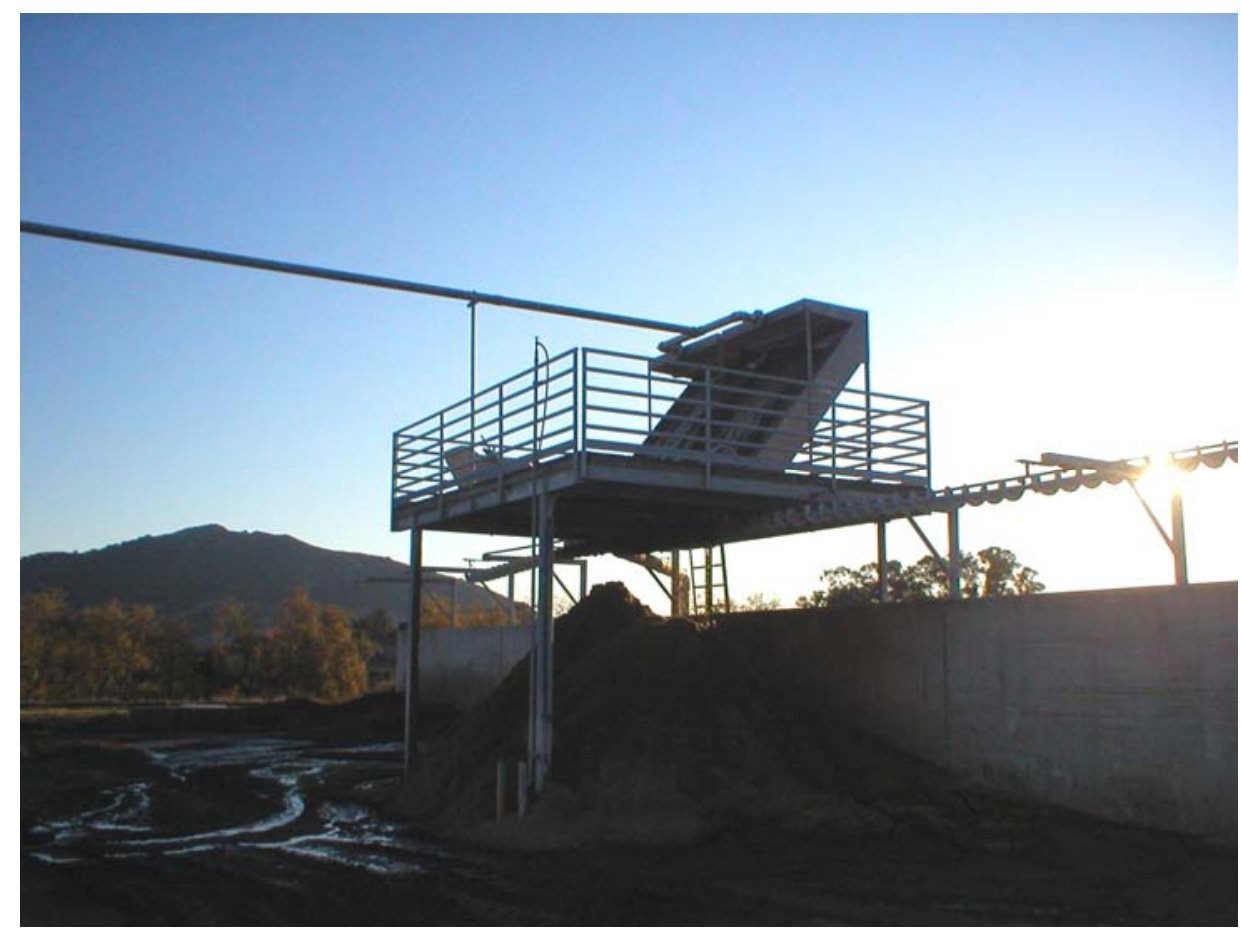

Figure 3.2: Wedge wire sloped screen at the Cal Poly Dairy.

Initial collections of wastewater were performed by hand using plastic 19-liter buckets to collect water from the surface of the holding pond. Later, wastewater was collected at the effluent of the sloped screen as this proved to be easier. This wastewater was first fed to a bench-scale anaerobic digester in the lab (Figure 3.3). The anaerobic digester consisted of a 208-liter plastic drum wrapped in 2-cm-thick foam insulation. The insulation provided a more stable temperature during ambient temperature swings. Attached through the bung hole in the drum lid was a $75-\mathrm{cm}$ tube that extended down $2 / 3$ rds of the total height of the drum. This tube was used for feeding the digester as well as pumping out effluent to feed the algae tanks. Initially, the digester was loaded using a peristaltic pump, but this was later replaced by manual gravity feeding to improve operational reliability. The approximate volume of wastewater in the digester was 130 liters. Wastewater was removed using a peristaltic pump. Biogas produced by the 
digester was collected using a 4.7-L Chemware ${ }^{\circledR}$ FEP gas sampling bag connected to the lid of the drum. An isolation valve was used in-between the gas collection bag and the digester to allow the bags to be exchanged with minimal air intrusion. A 91-cm long thermometer was threaded through the smaller bung on the lid of the drum to monitor temperature inside the digester; however this stopped working almost immediately after installation. Loadings of wastewater to the digester were typically done in 10 gallon batches once per week.

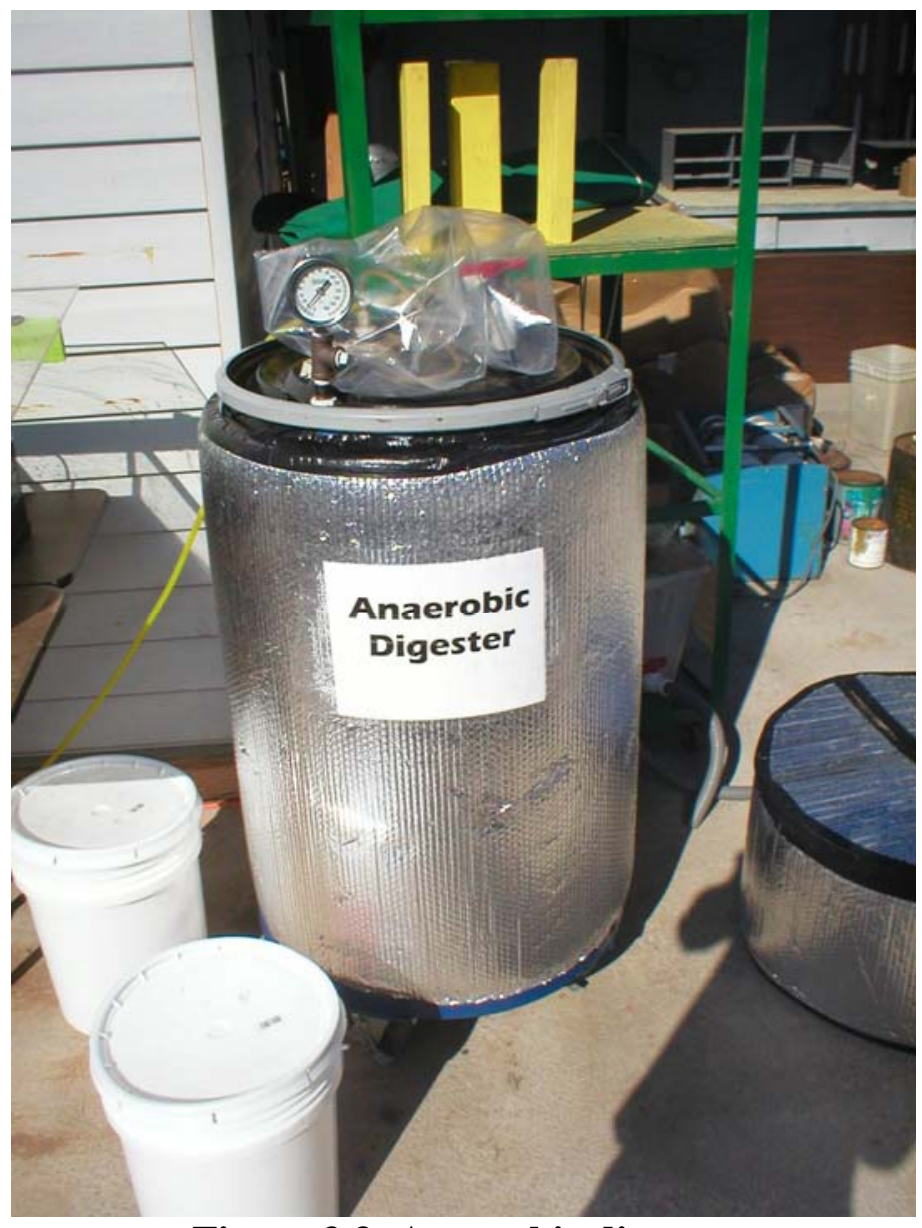

Figure 3.3: Anaerobic digester 


\subsection{Outdoor Algal Growth Containers}

The effluent from the digester was transferred to six 40-L glass tanks used as simulated pond bioreactors for algal growth (Figure 3.4). The water volume was $20 \mathrm{~L}$ in each bioreactor. The bioreactors were covered around the sides with black tape up to the height of the water surface so that light penetration was from the top only to better simulate lighting conditions in a large pond (Figure 3.5). A Plexiglas ${ }^{\circledR}$ cover was $^{-}$ constructed to exclude rainfall from all the tanks. Space was given between the cover and the bioreactors to allow for ventilation. Air stones, 12" inches long, were placed in the middle of each bioreactor to provide mixing and gas exchange. Air-sparging was at a rate of $1.5 \mathrm{~L} / \mathrm{min}$ divided among all of the algal growth containers. Additional $\mathrm{CO}_{2}$ was used in the batch experiments and sparged in with separate aquarium diffusers at a rate of $0.015 \mathrm{~L} / \mathrm{min}$ or approximately $1 \%$ the volume of air provided (Figure 3.6). It was determined using an LX-101 Lux Meter (Lutron Corporation) that the decrease of lux from the sunlight passing through the walls of each bioreactor and through the plastic cover was balanced out by the reflection from the white wall in the background. 


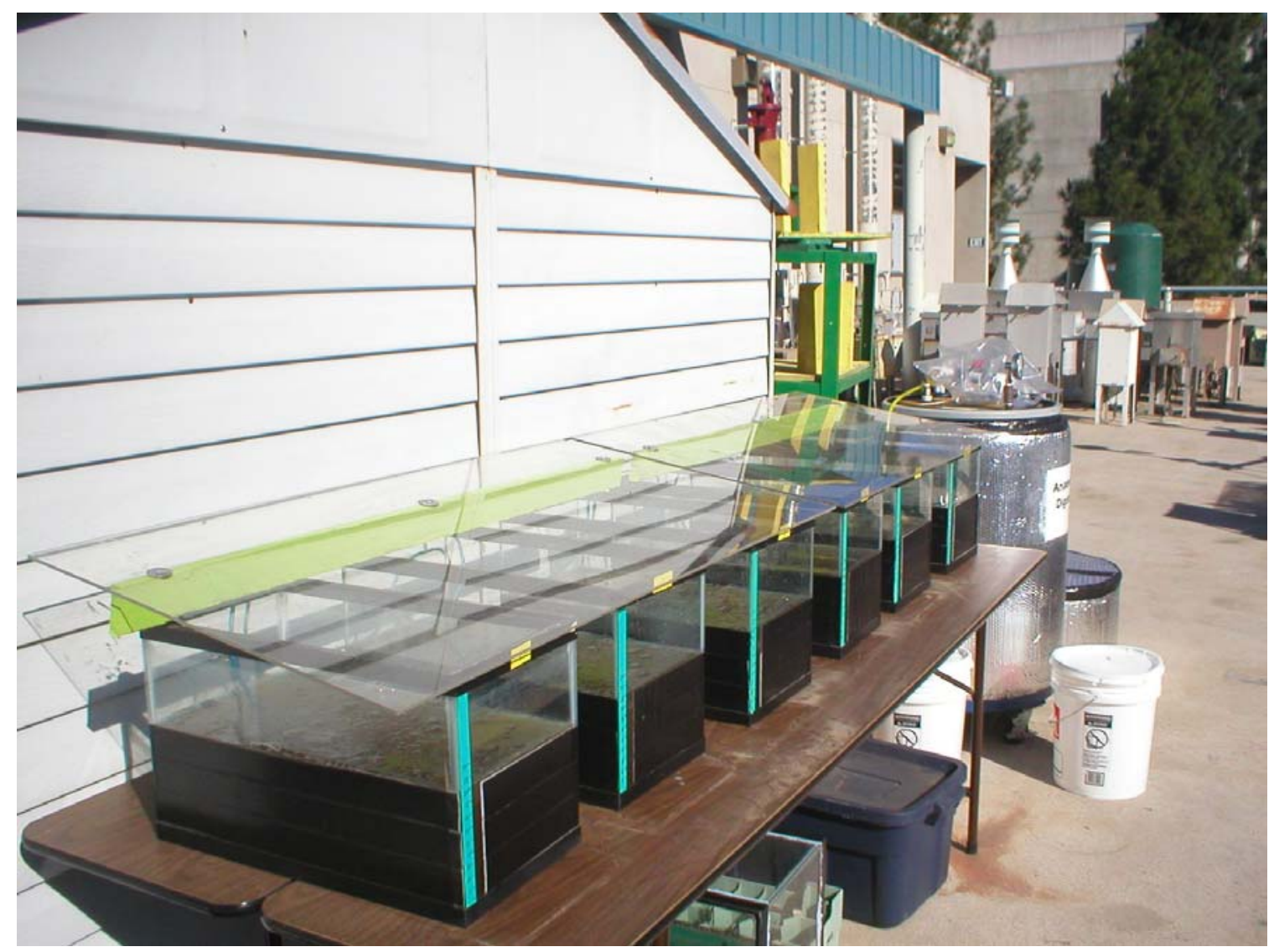

Figure 3.4: Algae bioreactors (and anaerobic digester in background)

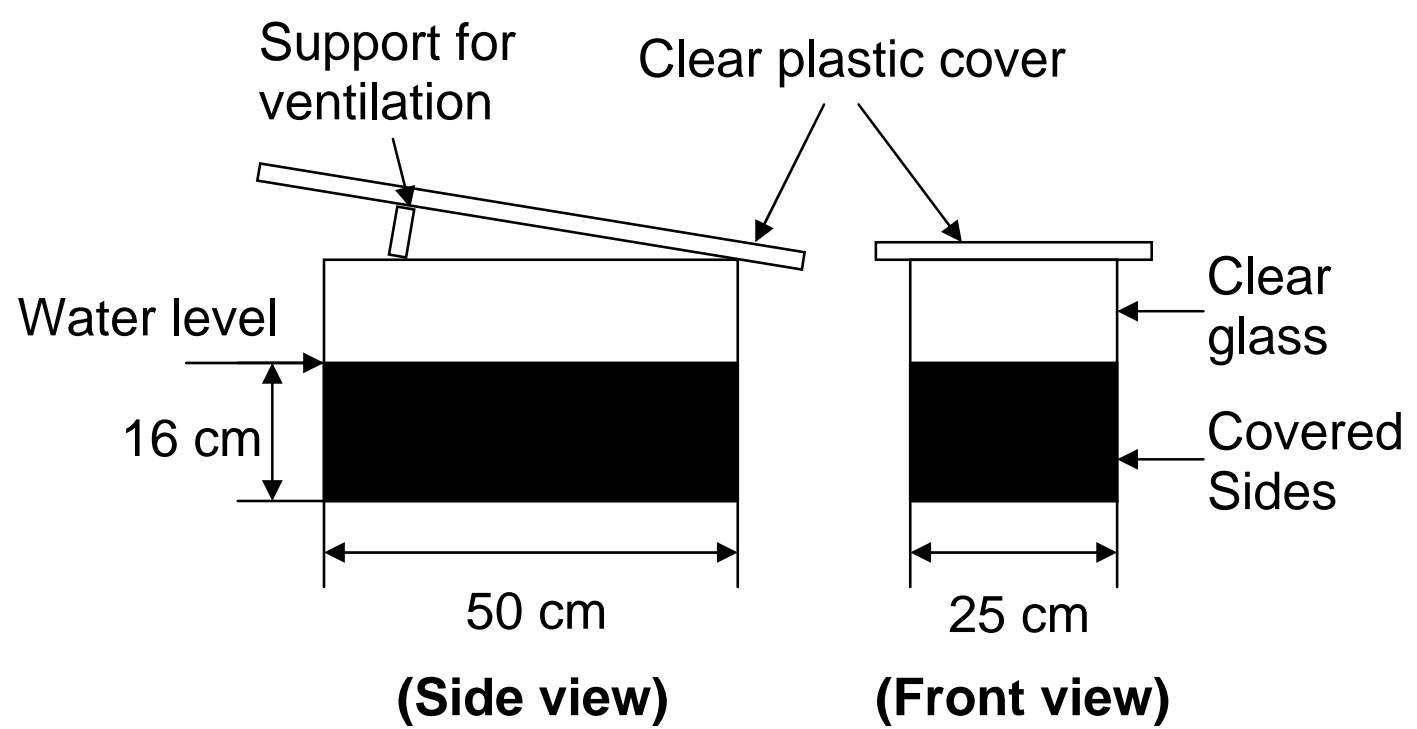

Figure 3.5: Diagram of an algae bioreactor. 


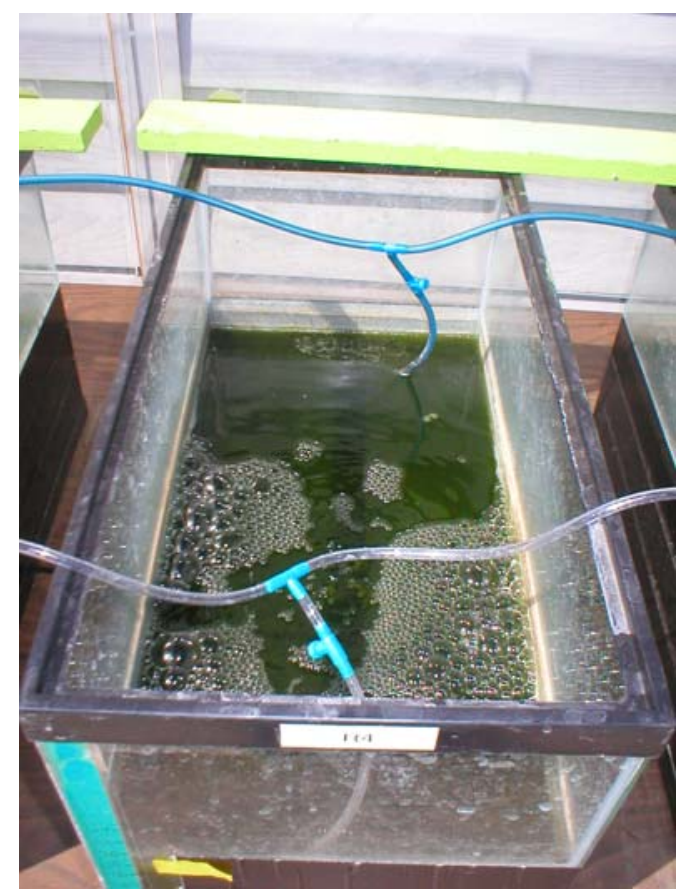

Figure 3.6 Algae bioreactor with air mixing and CO2 sparging

Preliminary experiments were performed using semi-continuous cycles of feeding anaerobic digester effluent to the bioreactors. Later experiments were performed in batch mode, which allowed for observation of algal growth curves.

\subsubsection{Operation of Initial Semi-Continuous experiments}

Initially, the algae bioreactors were run in a semi-continuous mode for 48 days. The bioreactors' retention times were initially 15, 10 and 5 days, and each was run in duplicate (Table 3.1). The different algae bioreactors were started with 1.3, 2.0, and 4.0 liters of wastewater diluted with tap water to make a total volume of $20 \mathrm{~L}$ each (Table 3.1). Algae inoculum was gathered from a local wastewater treatment pond located in the 
nearby town of Templeton. Inoculum was added to the algae bioreactors at approximately 500-mL volumes. The routine loadings made following the start up and inoculation were 1.3, 2.0 and 4.0 liters of wastewater per day to achieve the different retention times (Table 3.1). Prior to adding new wastewater from the anaerobic digester to the algae bioreactors, tap water was added to compensate for evaporation and to bring the total volume back to $20 \mathrm{~L}$ per bioreactor. The algae bioreactors were then rapidly mixed with glass stir rods and the volume of new wastewater that was to be added was removed using a 1-L beaker. The new wastewater was then added in the appropriate volumes using a beaker.

The initially chosen retention times using wastewater proved too short and did not allow for sufficient algal growth. Later, these predetermined loadings were replaced with variable-timed loadings determined by algal concentrations. If the algae bioreactors were not green with algae, new wastewater was not added again until a healthy green color returned. This initial semi-continuous experiment was used only to better design the later batch experiments. This initial period of testing also allowed the author to gain familiarity in the multiple analytical testing methods. 
Table 3.1 Initial and routine loadings for semi-continuous experiment

\begin{tabular}{cc|cc|c}
\hline Reactor & $\begin{array}{c}\text { Retention } \\
\text { Time } \\
\text { (days) }\end{array}$ & \multicolumn{2}{|c|}{ Initial Loading } & Cont. Loading \\
Wastewater & Tap water & $\begin{array}{c}\text { Wastewater } \\
\text { (L) }\end{array}$ & (L) & (Llay) \\
\hline R1 & 15 & 1.3 & 18.7 & 1.3 \\
R2 & 15 & 1.3 & 18.7 & 1.3 \\
R3 & 10 & 2.0 & 18.0 & 2.0 \\
R4 & 10 & 2.0 & 18.0 & 2.0 \\
R5 & 5 & 4.0 & 16.0 & 4.0 \\
R6 & 5 & 4.0 & 16.0 & 4.0 \\
\hline
\end{tabular}

\subsubsection{Batch Experiment}

Two batch experiments were run after the semi-continuous experiment. Two dilutions of wastewater were made in order to ensure that the light would not be limited due to the high turbidity of the wastewater and to insure that a full growth curve would be observed with the available. Tap water was used to dilute the wastewater to $25 \%$ wastewater in one set of triplicate tanks and to $10 \%$ wastewater in the other set of triplicate tanks. The tap water was sparged with air for approximately $30 \mathrm{~min}$. to strip chlorine prior to mixing with wastewater. Inoculum was provided from cultures of algae from previous experiments. Inoculum volume was selected to provide an initial VSS concentration of about $10 \%$ of the expected final VSS (assumed to be $\sim 500 \mathrm{mg} / \mathrm{L}$ based on earlier experiments). Therefore with an inoculum concentration of $500 \mathrm{mg} / \mathrm{L} \mathrm{VSS}$ and a $20 \mathrm{~L}$ total bioreactor volume, $2 \mathrm{~L}$ of inoculum were used per algae bioreactor. For each of the two feed concentrations, the three constituents (tap water, algae inoculum, and anaerobic effluent) were mixed to obtain a uniform feed solution for the triplicates of each dilution. A diagram of the dilutions and the numbering system used for each bioreactor is shown 
in Figure 3.7. The analytical testing that was performed consisted of TSS, VSS, pH, ammonia as $\mathrm{N}$, nitrate as $\mathrm{N}$, nitrite as $\mathrm{N}$, organic nitrogen, $\mathrm{TKN}$, total nitrogen, and phosphate as P.

10\% WW Dilution

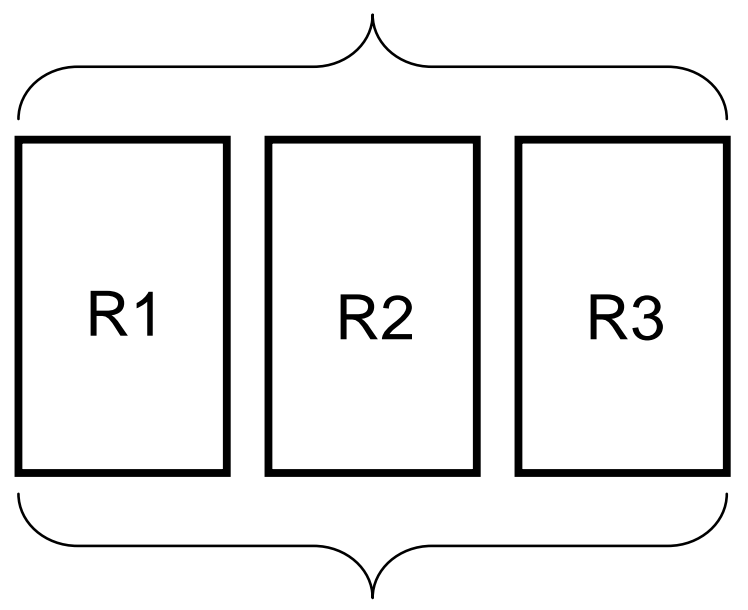

Individual Bioreactors

- 2 L Inoculum

- 2 L Wastewater

- $16 \mathrm{~L} \mathrm{H}_{2} \mathrm{O}$
25\% WW Dilution

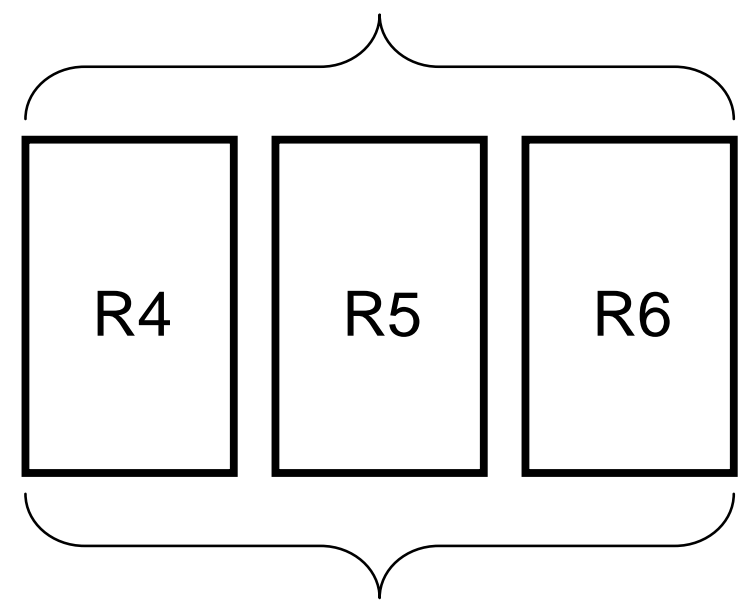

Individual Bioreactors

- 2 L Inoculum

- 5 L Wastewater

- $13 \mathrm{~L} \mathrm{H}_{2} \mathrm{O}$

Figure 3.7: Algae bioreactor media.

\subsection{Operating Conditions and Additional Testing}

Both experiments were started on March $19^{\text {th }} 2007$. The $25 \%$ dilution tanks were run for 15 days and the $10 \%$ dilution tanks for 13 days. Mixing was continuously provided by the air and $\mathrm{CO}_{2}$ sparging. Additional mechanical mixing was performed daily prior to sampling by hand using three or four glass stir rods bundled together. Temperature and $\mathrm{pH}$ were recorded at the time of each sampling after mixing. Tap water, which had been sparged with air to stripe any chlorine, was added to each bioreactor to replace the water that had been removed due to sampling. During the batch experiment, the average air temperature was $12.3^{\circ} \mathrm{C}$, and the average daily solar radiation was $203 \mathrm{~W} / \mathrm{m}^{2}$, which is typical for the San Luis Obispo area during that time of year (March-April). The weather 
data was provided by the California Irrigation Management Information System from Station 52 located in San Luis Obispo at Latitude $35^{\circ} 18^{\prime} 22^{\prime \prime} \mathrm{N} / 35.31$ and Longitude: $120^{\circ} 39^{\prime} 37^{\prime \prime} \mathrm{W} /-120.66$. The elevation was $330 \mathrm{ft}$.

\subsection{Algae Analysis}

\subsubsection{Algae Identification}

Samples were taken periodically from the algae bioreactors to identify the species growing in the cultures. A trinocular Olympus CX 41 optical microscope with phase contrast and an Infinity 2 digital camera were used for algae identification. Photomicrographs were taken to document the species present and were then used for comparison with micrograph catalogs of known genera.

\subsubsection{Total Suspended Solids}

In the batch experiments, the total suspended solids (TSS) and volatile suspended solids (VSS) were determined daily. Samples were taken from the algae bioreactors at 3 PM each day and immediately tested for TSS and VSS. The testing for both TSS and VSS was conducted according to Standard Methods 2540 D (APHA, 1995). The filters used for solids testing were 1.2-micron Fisher G4 glass fiber filters with 47-mm diameters. Mass measurements were made using a 5-decimal point electronic balance. Samples were also stored in HDPE containers at $4^{\circ} \mathrm{C}$ for nitrite, nitrate, phosphate, ammonia, and lipid analytes. Additional samples were acidified to less than a $\mathrm{pH}$ of 2 and stored at $4{ }^{\circ} \mathrm{C}$ for Total Kjeldahl Nitrogen analysis. 
Filters were first rinsed with DI water using a Millipore filter apparatus and then ashed in a muffle furnace at $525^{\circ} \mathrm{C}$ for $15 \mathrm{~min}$. The filters were then cooled in a dessicator and stored until needed in a $105^{\circ} \mathrm{C}$ oven. Just prior to analysis, filters were individually placed into aluminum foil trays and weighed. After weighing, the filter was placed on the Millipore filter apparatus and a known aliquot of sample was passed through the filter. The filter was then removed using tweezers and placed back into its individual tray. Trays were then placed in the $105^{\circ} \mathrm{C}$ oven for at least 2 hours, but typically over night. Trays were again weighed to obtain a TSS. After weighing for TSS the trays were placed in the muffle furnace at $525^{\circ} \mathrm{C}$ for $15 \mathrm{~min}$. The trays were removed and placed in the dessicator to allow cooling. The samples were again weighed, this time to obtain a VSS.

\subsection{Nutrient Analyses}

\subsubsection{Ammonia}

Ammonia was measured using an ammonia-specific electrode. This analytical procedure was carried out by Adam Feffer, a fellow M.S. student at Cal Poly. The details of the method can be found in Appendix A, which was written by Mr. Feffer.

\subsubsection{Total Kjeldahl Nitrogen}

Total Kjeldahl nitrogen (TKN) analyses were carried out with the assistance of Adam

Feffer and Kyle Poole (another M.S. student) to determine total organic nitrogen. Details of the method can be found in Appendix B, which was written by Mr. Feffer. 


\subsubsection{Nitrate, Nitrite, and Phosphate by Ion Chromatography}

Nitrite, nitrate, and phosphate were analyzed using ion chromatography. Ion

chromatography operates on the principal of ion exchange, in which ions bound to a solid surface are displaced by ions in solution. The sample to be analyzed is filtered and injected into a stream of eluent (an electrolyte solution) and passed through a series of ion exchange columns. The ions of interest are separated on the basis of their affinities for an ion exchange resin contained in guard and separator column. The guard column contains the same packing material as the separator columns, and acts as an inexpensive replaceable shield for the separator column. The separated anions in the eluent solution are then passed through a suppressor. The suppressor eliminates the background conductivity of the eluent. The remaining conductivity is due to the ions in the sample. The solution then enters the conductivity cell where the electrical conductivity is measured. The ions are identified based on their retention time as compared to standards. Quantification is by measurement of peak areas for each anion. Concentrations are then calculated using a calibration curve made from standards of known concentration.

For these analyses, a Dionex DX 120 Ion Chromatograph was used with a setup including;

- AG9-HC IonPac ${ }^{\circledR}$ Guard Column

- $\quad$ AS9-HC 4mm IonPac ${ }^{\circledR} \mathrm{IC}$ column

- DS4-1 Detection Stabilizer

- AS40 Automated Sampler

- Dionex Chromeleon Software 
Sodium bicarbonate with a concentration of $9 \mathrm{mM}$ was used as eluent. The eluent was prepared by degassing Grade 1 DI water with Ultra High Purity helium for 30 minutes and diluting concentrated $0.5 \mathrm{M}$ sodium carbonate to create $9 \mathrm{mM}$ eluent. Ultra High Purity Helium was supplied to the IC at a pressure of $40 \mathrm{psi}$. Internal pressure of the IC was maintained between 2300 and 2500 psi. Flow of eluent was set to $1.10 \mathrm{~mL} / \mathrm{min}$. The eluent was allowed to flow for at least 1 hour prior to running any samples through the column. The total run time for each sample was 30 minutes.

Standards were prepared using Dionex 7-Anion standard solution. Three separate dilutions $(1 \%, 5 \%$, and $10 \%)$ were made to create a 3 -point calibration curve for each of the anions analyzed. These dilutions created three separate concentrations for each anion. Nitrite as $\mathrm{N}$ had concentrations of $0.20,1.00$, and $2.03 \mathrm{mg} / \mathrm{L}$. Nitrate as $\mathrm{N}$ had concentrations of $0.14,0.81$, and $1.65 \mathrm{mg} / \mathrm{L}$. Phosphate as $\mathrm{P}$ had concentrations of 0.46 , 2.24, $4.57 \mathrm{mg} / \mathrm{L}$. Samples were filtered through 0.22- $\mu \mathrm{m}$ Millipore Express PLUS ${ }^{\circledR}$ Membrane filters with the assistance of a HDPE plunger. Samples were placed into 5$\mathrm{mL}$ Dionex poly vials and caped with Dionex 20- $\mu \mathrm{m}$ filter caps. A spike of 7-anion solution was added to one sample for each set of samples analyzed for quality control. At the start of each run, a DI rinse was used prior to running any samples. After any standards were run, a DI blank was analyzed to confirm that there had been no contamination and to show any background noise from the instrument. If more than 15 samples were run in one set, a second 3-point calibration curve was created to assess any calibration drift. 


\subsection{Total Lipid Analysis}

Lipid content of the algae was measured during various growth stages to determine lipid productivity. Lipid content was analyzed gravimetrically by a procedure adapted from Bligh and Dyer (1959) and modified using Benemann and Tillett (1987). This method consisted of a solvent extraction to isolate lipids from cell biomass and water. At the time of sample collection, VSS was measured to determine the concentration of algae biomass in the water sample. A $200-\mathrm{mL}$ aliquot of the same sample was also concentrated into a small pellet by centrifuging in 50-mL PTFE centrifuge tubes. To accomplish this, a portion of each sample was poured into a single 50-mL centrifuge tube, which was then centrifuged at approximately $7000 \mathrm{rpm}$ for 2 minutes. The centrifuge tubes were then removed and the supernatant was then decanted. The tubes were then filled again with remaining sample. This procedure was repeated until the entire sample had been centrifuged. The samples were then re-suspended with $4 \mathrm{~mL}$ of DI water and frozen until enough samples were collected to run a set of extractions. The frozen samples were thawed and $5 \mathrm{~mL}$ of chloroform and $10 \mathrm{~mL}$ of methanol were added. The samples were then sonicated using a Branson Sonifier 250 with a Model \#102 tip continuously submerged in the centrifuge tube liquid for $1 \mathrm{~min}$. at the maximum power output setting of 8 . The centrifuge tubes containing the samples were then placed horizontally on a shaker table over night ( $\sim 6$-cm oscillation at $\sim 2$ cycles per second). The next day, an additional $5 \mathrm{~mL}$ of chloroform and $5 \mathrm{~mL}$ of DI water were added to make the final ratio of chloroform:methanol:water to be 10:10:9. The samples were then vortex mixed for 30 seconds. After the samples had been completely homogenized, they were centrifuged at $7000 \mathrm{rpm}$ for 4 minutes. The lipids are soluble in the chloroform, 
which forms a dense layer at the bottom of the centrifuge tube. The remaining cell debris creates a middle layer, while the methanol and water create a uniform top layer. A diagram of the extraction is shown in Figure 3.8. The lipid-chloroform layer was then removed using a pipette and filtered through $0.2 \mu \mathrm{m}$ nylon filter (using a syringe) and deposited into a tared aluminum tray. The tray was then placed into a dessicator box sparged with nitrogen gas to allow the chloroform to evaporate. A second extraction was performed by adding an additional $10 \mathrm{~mL}$ of chloroform to the centrifuge tube and the mixture was again vortexed and centrifuged. This second extraction was placed into a separate tared tray. A photograph of the fume hood with most of the extraction equipment used is shown in Figure 3.9. The trays were then placed in an oven at $105^{\circ} \mathrm{C}$ under a fume hood for one hour to drive off any water and remaining chloroform. After allowing the trays to cool, they were weighed to the nearest $0.1 \mathrm{mg}$. A photograph of the lipids after the chloroform has been evaporated is shown in Figure 3.10. Judging from the green color of the dried lipids some chlorophyll has remained in the lipid fraction. 


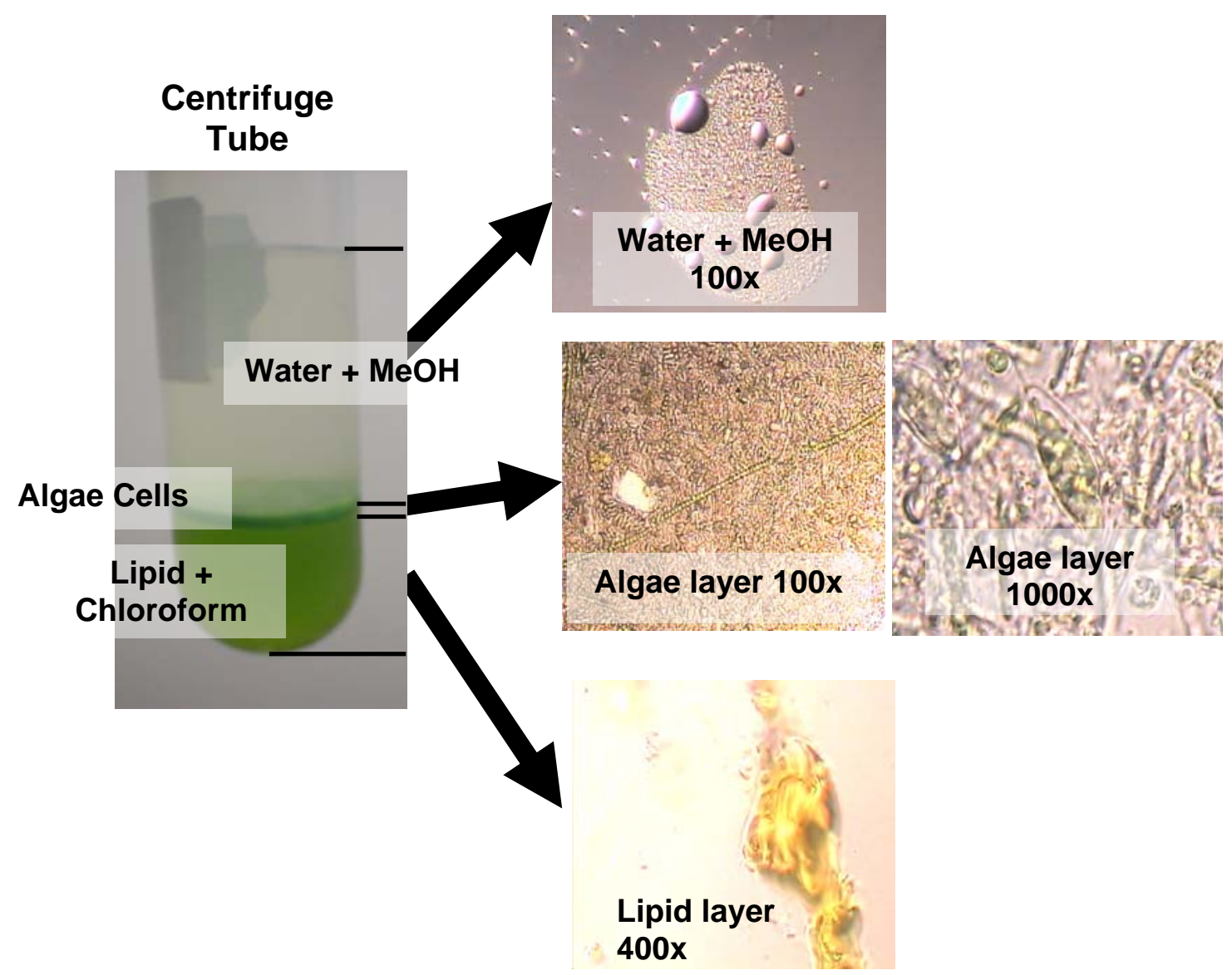

Figure 3.8: Lipid extraction diagram 


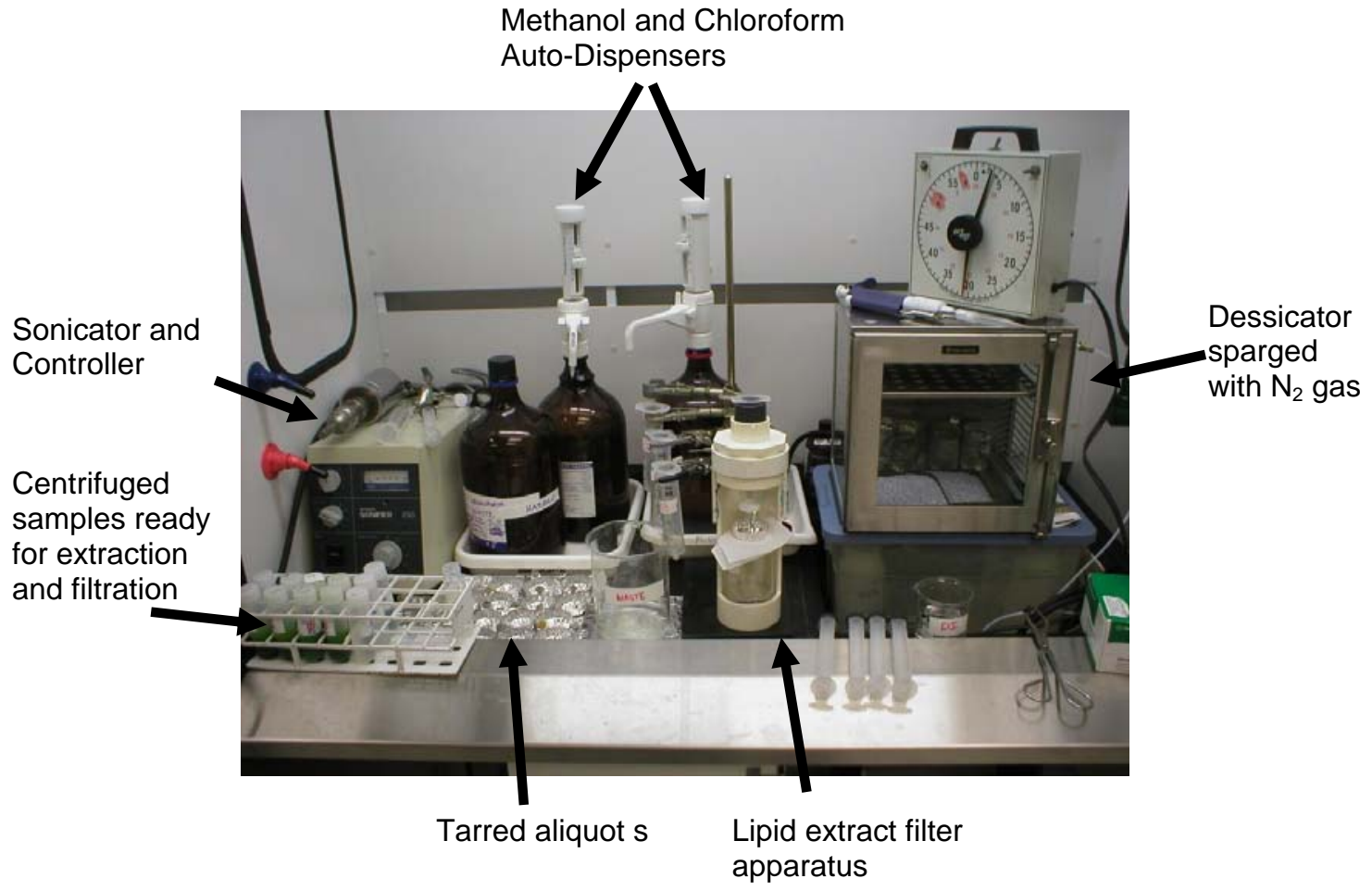

Figure 3.9: Fume hood with lipid extraction equipment

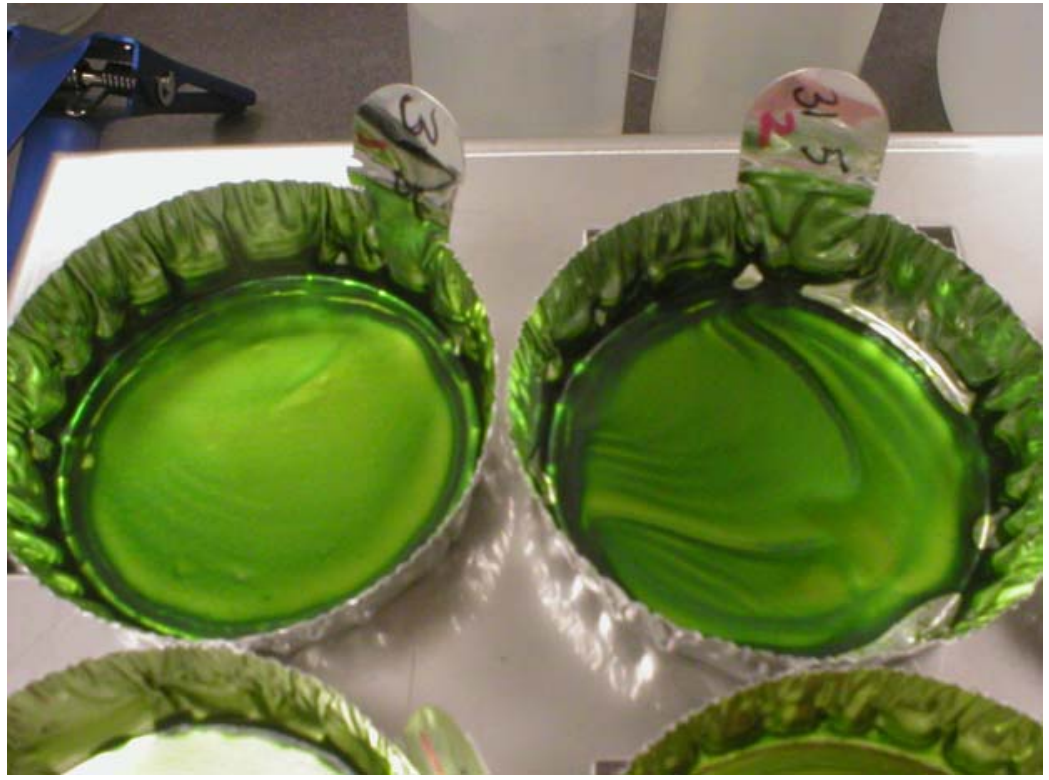

Figure 3.10: Dried lipid extract 


\subsection{Dissolved Oxygen Measurement}

The amount of dissolved oxygen (DO) present in water is an indication of the health of that aquatic environment and can be used as an indicator of algae photosynthesis. In order to obtain an estimate of the lowest DO concentrations in the algae tanks, during one day, DO was measured periodically from before dawn to mid-morning. DO was measured using a portable Thermo Orion Model 810 with and Orion DO probe. 


\section{CHAPTER 4: RESULTS AND DISCUSSION}

This section presents results for the preliminary semi-continuous experiment first followed by the batch experiment results.

\subsection{Semi-Continuous Experiment}

The initial goal of the semi-continuous experiment was to reach a steady state of algal biomass with timed feedings of wastewater, however this could not be achieved. A few of the algae bioreactors experienced "culture crashes" where there would be healthy populations of algae one day and then a heavily diminished population of algae the next. Other algae bioreactors failed to grow algae despite repeated inoculations. Results are presented below only for algae bioreactor R1, which was one of the only algae bioreactors that sustained high algae concentrations through the 48 days of the experiment.

\subsubsection{Biomass Results for Semi-Continuous Experiment}

After a 10-day lag phase, the solids concentrations increased steadily in the R1 bioreactor (Figure 4.1). The biomass concentration reached a high of $1.1 \mathrm{~g} / \mathrm{L}$ VSS on Day 39 (Figure 4.1). Because of slow growth of algae, the amount of time in between loadings was increased up to 10 days, making equivalent retention times of over 105 days. Also of interest is how the difference between TSS and VSS increased over time (Figure 4.1). The increase in TSS may have been due to the anaerobic digester not performing properly. The $\mathrm{pH}$ remained level just below 10 for the majority of the experiment (Figure 4.1). The high $\mathrm{pH}$ was primarily due to $\mathrm{CO}_{2}$ uptake by the algae as lower $\mathrm{pHs}$ 
were observed in later experiments with $\mathrm{CO}_{2}$ sparging. This lack of $\mathrm{CO}_{2}$ sparging could account for the slower growth rates observed.

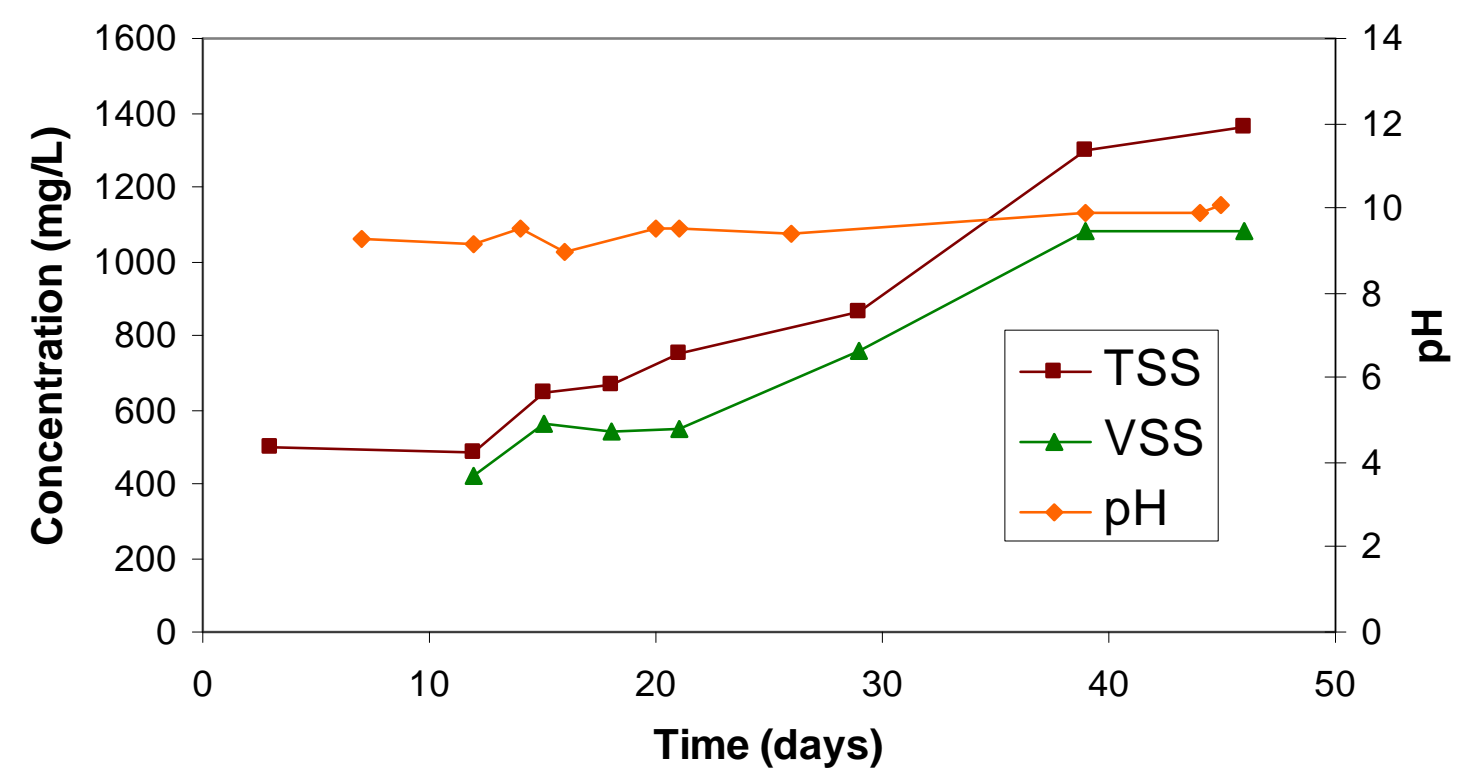

Figure 4.1: Biomass and pH for semi-continuous experiment for R1 tank.

One other reason for the slow growth of the algae was probably the high opacity of the influent causing light limitation and allowing aerobic heterotrophic bacteria to dominate. The opacity was cause by the high suspended solids concentration of the dairy wastewater. Therefore, the subsequent batch experiments were run with $10 \%$ and $25 \%$ dilutions of wastewater to prevent light limitations as well as supplementation with sparged $\mathrm{CO}_{2}$.

\subsubsection{Biochemical Oxygen Demand during Semi-Continuous Experiment}

Biochemical oxygen demand (BOD) measurements were performed during this initial semi-continuous experiment. The BOD tests were performed on samples taken directly from the algae bioreactors without separation of algae from the effluent. The measured BOD therefore included the respiration and degradation of the algae present in the 
sample. Algae tank R1 had an average $\mathrm{BOD}_{5}$ of $146 \mathrm{mg} / \mathrm{L}$ with a standard deviation of $9.3 \mathrm{mg} / \mathrm{L}$. Again, this includes the particulate BOD from the VSS, so it is not indicative of wastewater effluent since BOD would not be so extensive in full-scale production because the algae would have been harvested from the wastewater before discharge. In retrospect, a soluble BOD test should have been performed by first filtering the samples to remove the algae. Soluble BOD would have given a better perspective on what the BOD effluents would have actually been.

\subsubsection{Nutrient Removal Semi-Continuous Experiment}

Nutrient removal was determined by comparing the influent and effluent concentrations of nitrite, nitrate and phosphate throughout the 48-day experiment. Ammonia was not analyzed for this initial experiment. The influent nitrite was non-detect, however a spike of nitrite was observed in the effluent up to $4 \mathrm{mg} / \mathrm{L} \mathrm{NO}_{2}{ }^{-}$as $\mathrm{N}$ at Day 25 (Figure 4.2). The increase in nitrite suggests that partial nitrification could have occurred in the middle of the experiment. 


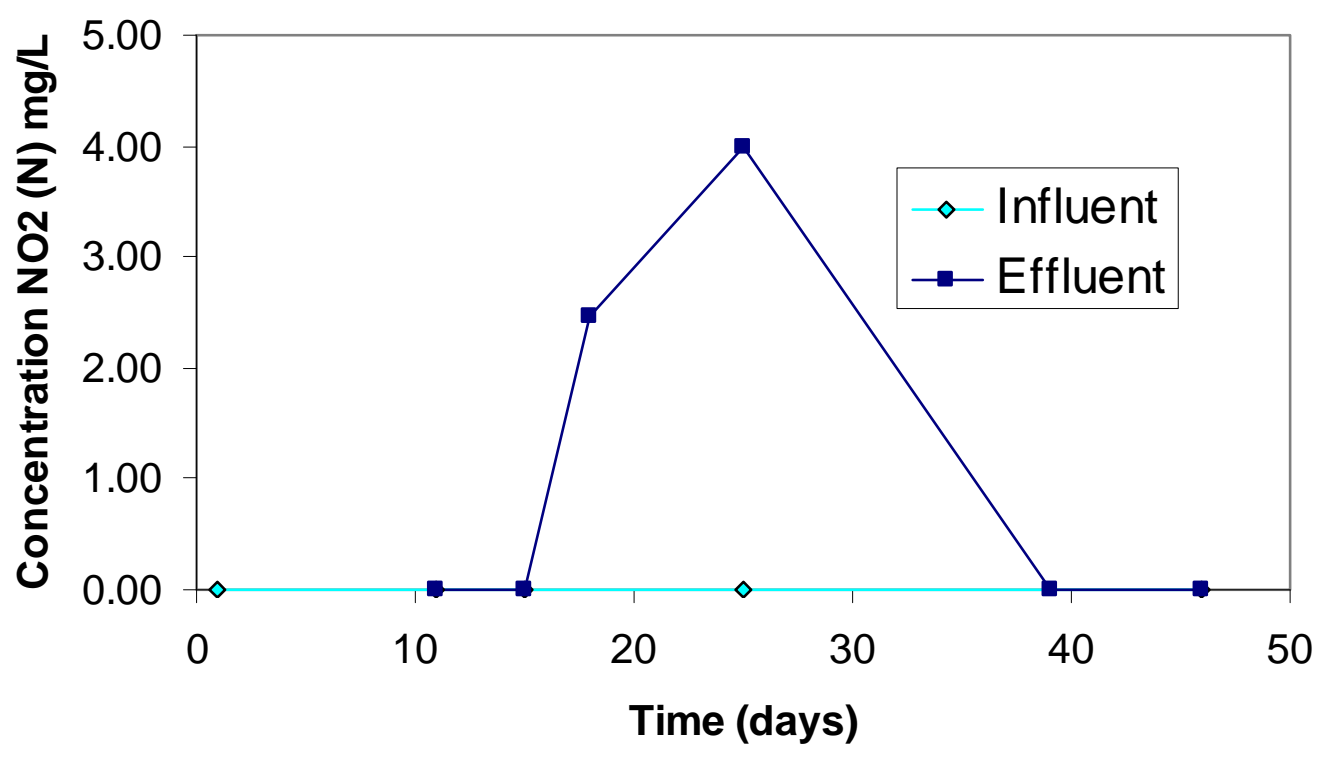

Figure 4.2: Nitrite concentrations during the semi-continuous experiment.

The amount of nitrate in the influent was relatively small, with the highest concentration being recorded at less than $0.7 \mathrm{mg} / \mathrm{L}$ (Figure 4.3). The effluent was reduced to below 0.1 $\mathrm{mg} / \mathrm{L} \mathrm{NO}_{3}{ }^{-}$as $\mathrm{N}$ except for an initial spike (Figure 4.3). Again these concentrations are relatively small and are not of much importance when compared to the amount of ammonia that is present as observed in later batch experiments. 


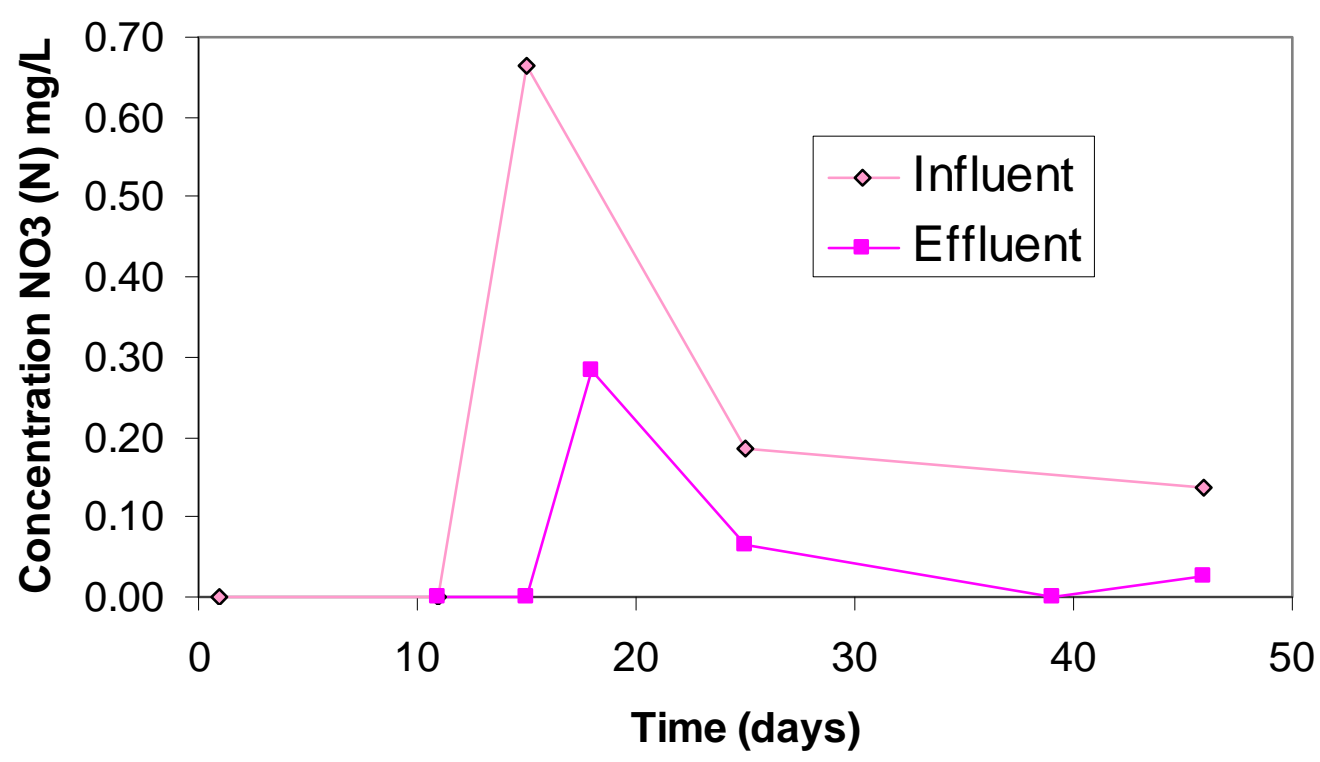

Figure 4.3: Nitrate removal during the semi-continuous experiment.

The phosphate removal was the most extensive of the nutrients analyzed. The influent concentration average was greater than $12 \mathrm{mg} / \mathrm{L} \mathrm{PO}_{4}{ }^{3-}$ as $\mathrm{P}$, and the effluent concentration average was $1.1 \mathrm{mg} / \mathrm{L} \mathrm{PO}_{4}{ }^{3-}$ as $\mathrm{P}$ (Figure 4.4). Even as the influent phosphate concentration peaked to $25 \mathrm{mg} / \mathrm{L}$, the effluent phosphate concentration remained low $(<2.0 \mathrm{mg} / \mathrm{L})$. 


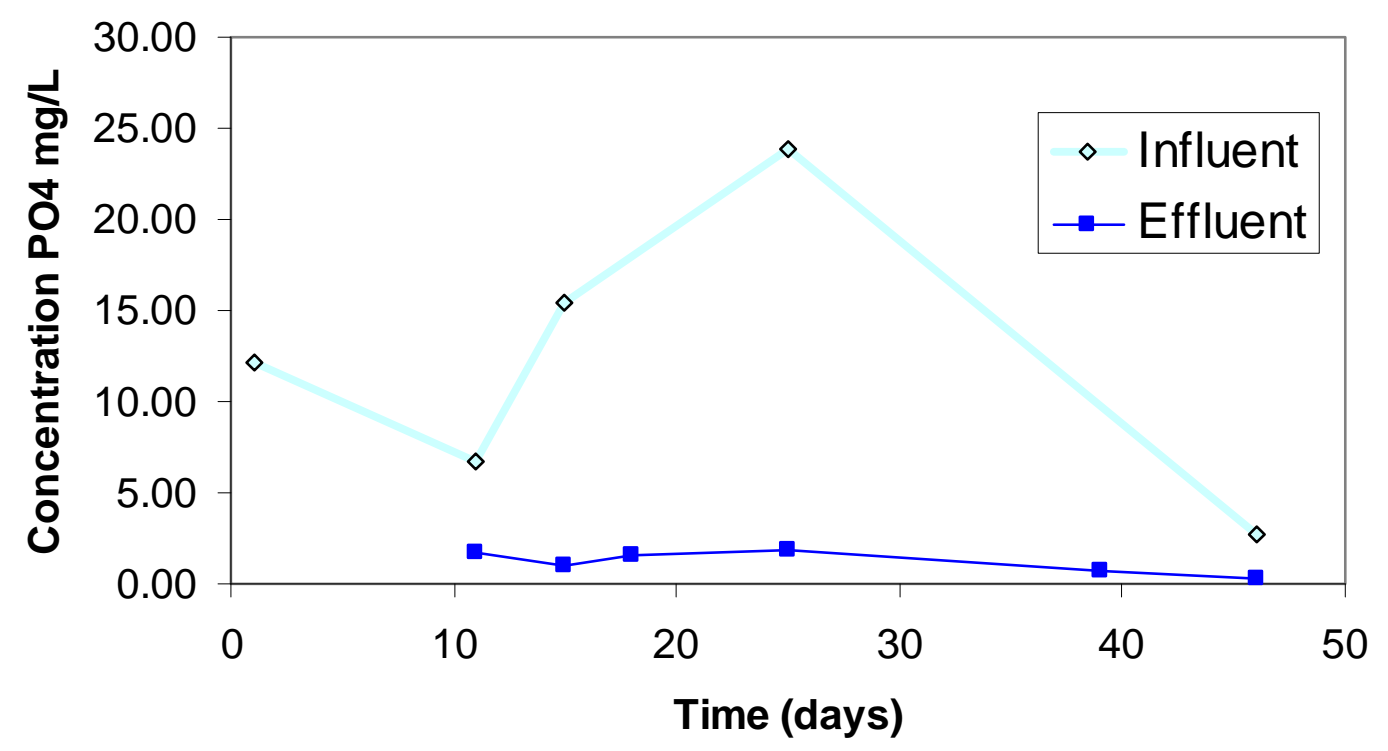

Figure 4.4: Phosphate removal during the semi-continuous experiment.

\subsubsection{Initial Total Lipid Content during the Semi-Continuous Experiment}

Lipid was extracted from samples from four of the six algae bioreactors. On Day 25 of the semi continuous experiment, the total lipid percentages ranged from $9-23 \%$ by weight (Table 4.1). Duplicate lipid determinations were not made during this initial experiment. In addition, it is difficult to determine actual lipid productivity due to the sporadic loading rates, so a batch experiment was conducted subsequently to facilitate determination of lipid productivity. 
Table 4.1: Lipid percentage in biomass during semi-continuous experiment

\begin{tabular}{ccc}
\hline $\begin{array}{c}\text { Algal } \\
\text { Bioreactor }\end{array}$ & VSS (mg/L) & Lipid \% \\
R2 & 440 & $18 \%$ \\
R3 & 660 & $23 \%$ \\
R4 & 520 & $14 \%$ \\
R5 & 710 & $9 \%$ \\
\hline
\end{tabular}

\subsection{Batch Experiment Results}

This subsequent experiment was performed in batch mode as compared to the initial semi-continuous experiment. The wastewater was diluted to $25 \%$ or $10 \%$ at the start of the experiment and there were no additional loadings of wastewater. The algae bioreactors were sparged with $\mathrm{CO}_{2}$ to increase the algae growth rate. An average $\mathrm{pH}$ of 7.6 was maintained for both dilutions. The results for the batch experiment were analyzed to a greater extent than the semi-continuous experiment.

\subsubsection{Algae Identification}

The algae species present in the batch reactors were dominated by Scenedesmus (Figure 4.5), followed by Micractinium (Figure 4.6), Chlorella, and Actinastrum (Figure 4.7). Algae identifications were made throughout the experiment, and the photomicrographs shown are a typical representation of the algae that were observed. 


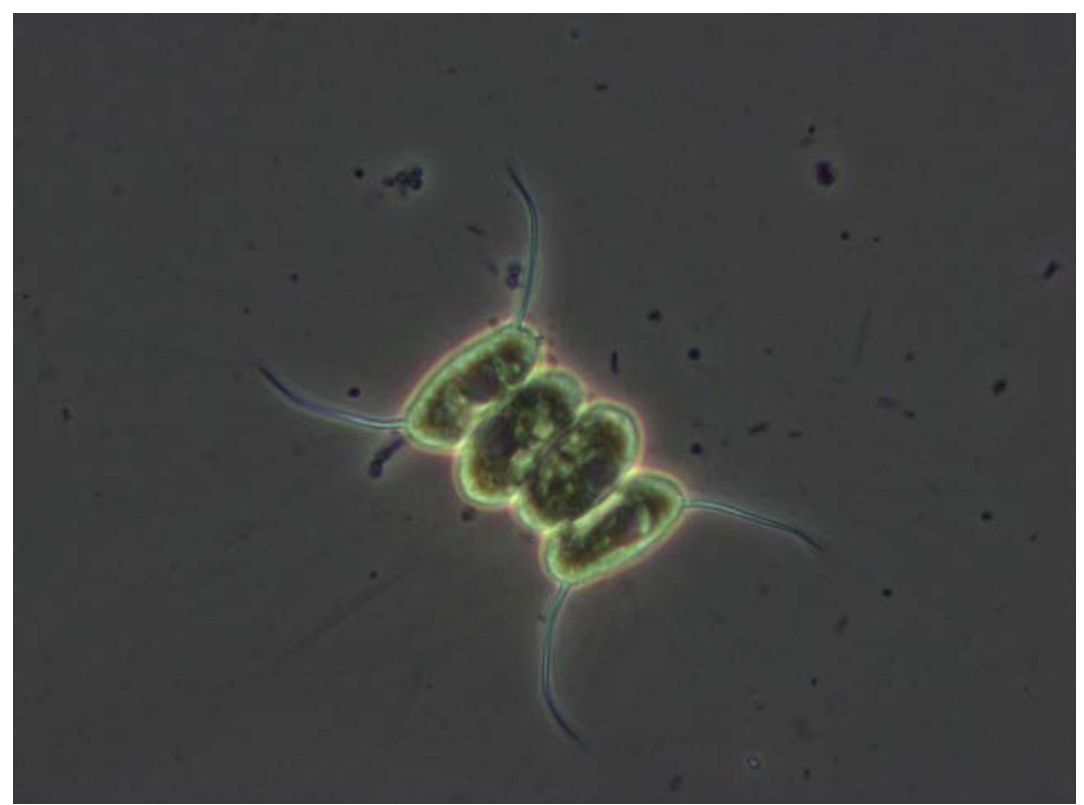

Figure 4.5: Photomicrograph of Scenedesmus at 1000x (phase contrast) at Day 45 of the semi-continuous experiment R5.

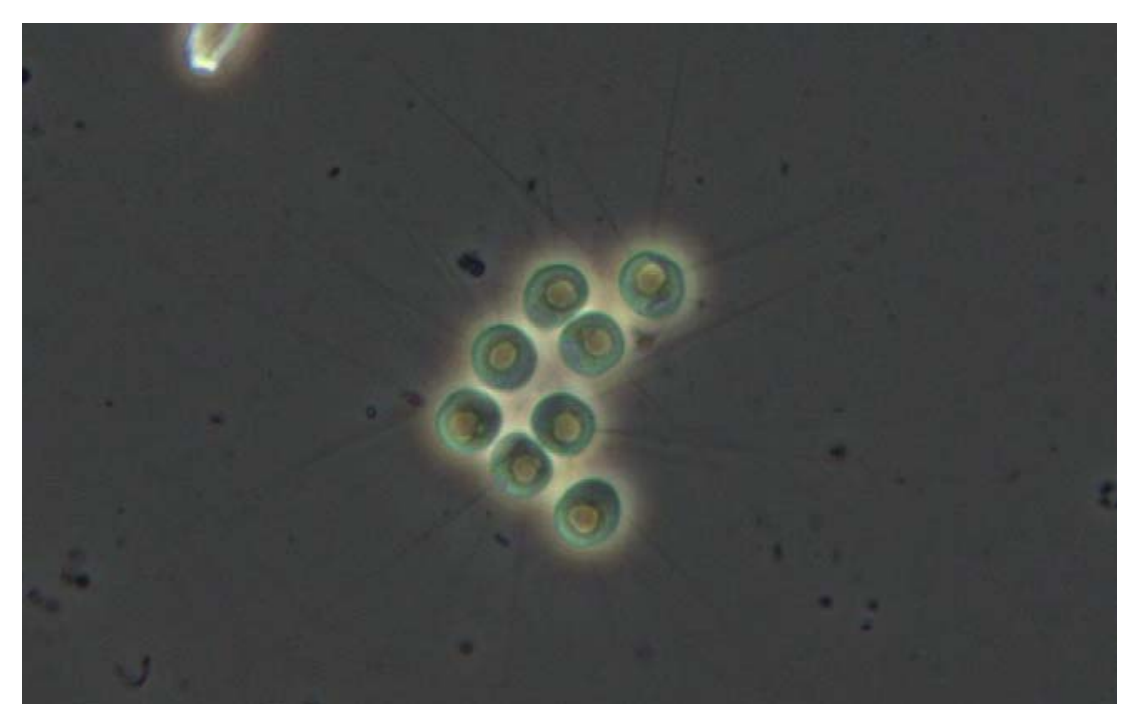

Figure 4.6: Photomicrograph of Micractinium at 100x (phase contrast) on Day 45 of the semi-continuous experiment $R 5$. 


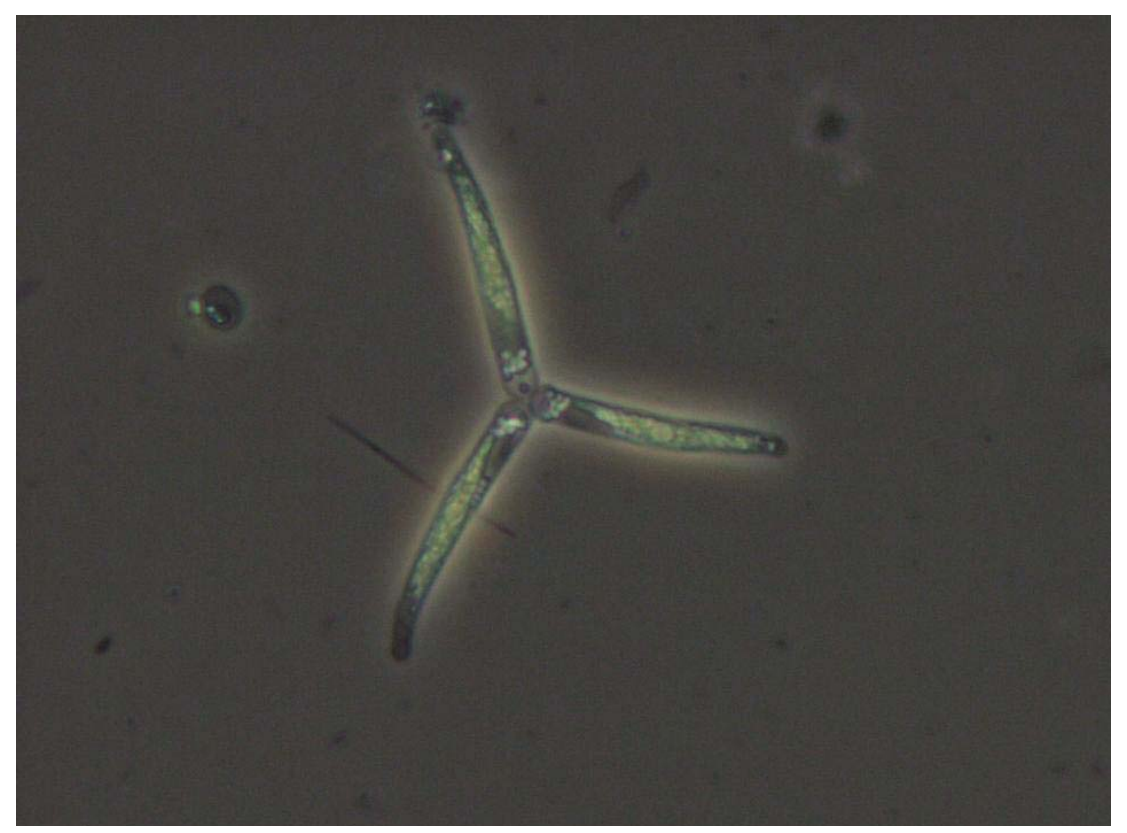

Figure 4.7: Photomicrograph of Actinastrum at 1000x (phase contrast) on Day 27 of the semi-continuous experiment R1.

In addition to algae being identified as single cells, it is important to note that there were also flocculations of algae which agglomerated together. A photomicrograph of a flocculation of Scenedesmus is shown in Figure 4.8. Flocculation is an important factor in settling and removal of algae from wastewater because as the mass of this flocculation gets larger so does the potential for it to settle to the bottom. This process and its use as a low cost and effective practice for harvesting and meeting discharge requirements may be a key component for making an economical algae-to-biofuels system. 


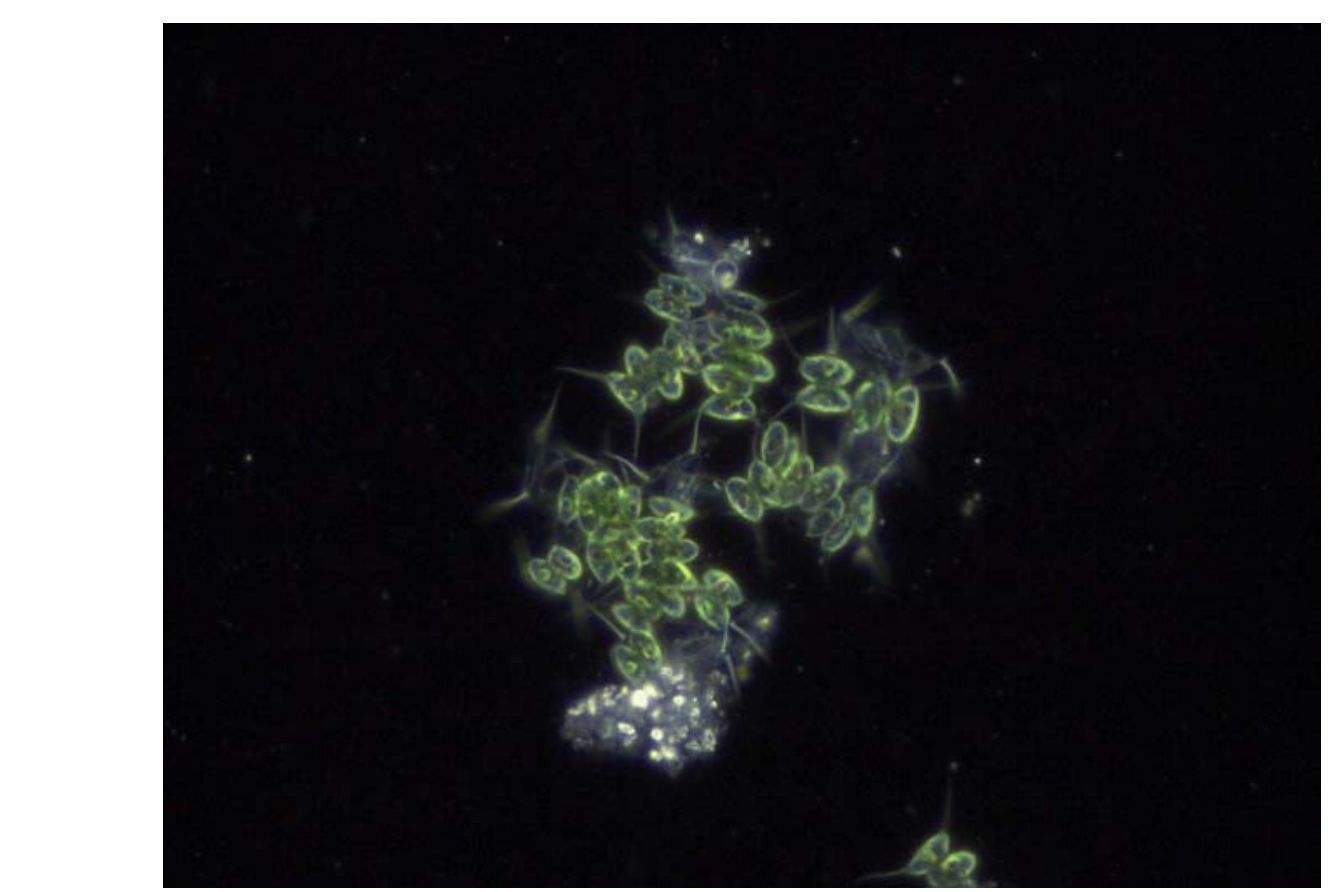

Figure 4.8: Photomicrograph of flocculated Scenedesmus at 400x (Dark Phase) on Day 45 of the semi-continuous experiment R4.

\subsubsection{Initial Conditions}

The initial characteristics of the wastewater are reported in Table 4.2. Nitrogen was all in the form of ammonia and organic nitrogen, with nitrate and nitrite near their detection limits. This is typical of the reduced conditions expected in the anaerobic wastewater. The TSS concentration was 283 and $135 \mathrm{mg} / \mathrm{L}$ for the $25 \%$ and $10 \%$ dilution tanks. The initial $\mathrm{pH}$ of both wastewater dilutions were a little above a neutral $\mathrm{pH}$ of 7 . 
Table 4.2: Initial characteristics of diluted dairy wastewater.

\begin{tabular}{lcc}
\hline Wastewater characteristics & 25\% Wastewater & 10\% Wastewater \\
\hline TSS (mg/L) & 283 & 135 \\
VSS (mg/L) & 220 & 120 \\
$\mathrm{pH}$ & 7.9 & 7.7 \\
Ammonia as N (mg/L) & 30.5 & 16.3 \\
Nitrate as N (mg/L) & 0.01 & 0.05 \\
Nitrite as N (mg/L) & $<0.01$ & 0.04 \\
Organic Nitrogen (mg/L) & 50.7 & 20.2 \\
TKN (mg/L) & 81.0 & 36.5 \\
Total Nitrogen (mg/L) & 81.0 & 36.6 \\
Phosphate as P (mg/L) & 2.55 & 1.8 \\
\hline
\end{tabular}

\subsubsection{Biomass Results for Batch Experiments and Growth Curves}

Biomass concentrations followed a typical microbial growth curve with a lag, exponential, stationary and death phase (Figure 4.9 and Figure 4.10). The maximum biomass concentration of $915 \mathrm{mg}$ VSS/L was reached by Day 13 for the $25 \%$ batch reactors (Figure 4.9), and 490 to $520 \mathrm{mg} \mathrm{VSS/L}$ was reached from Days 6-10 for the $10 \%$ batch reactors (Figure 4.10). The higher biomass production for the $25 \%$ dilution is likely due to the higher nutrient concentrations available (Table 4.2), since algal growth was likely nutrient limited, as described below. The maximum specific growth rate $\left(\mu_{\max }\right)$ for both dilutions was calculated by plotting the natural log of the cell concentration versus time. The maximum specific growth rate is equivalent to the slope 
of the trend line for the plot and was equal to $0.13\left(\right.$ day $\left.^{-1}\right)$ for the $25 \%$ dilution reactor (Figure 4.11) and $0.24\left(\right.$ day $^{-1}$ ) for the $10 \%$ dilution (Figure 4.12). The lower $\mu_{\max }$ in the $25 \%$ dilution reactor was probably due to the higher initial turbidity, which can be observed through TSS (Table 4.2), decreasing the available light compared to the $10 \%$ dilution reactor. These maximum specific growth rates observed here are greater than those calculated for algae by Feffer (2007) of $0.056\left(\right.$ day $\left.^{-1}\right)$ but 3.5 times lower than those observed by Shelef (1968) of $0.85\left(\right.$ day $\left.^{-1}\right)$.

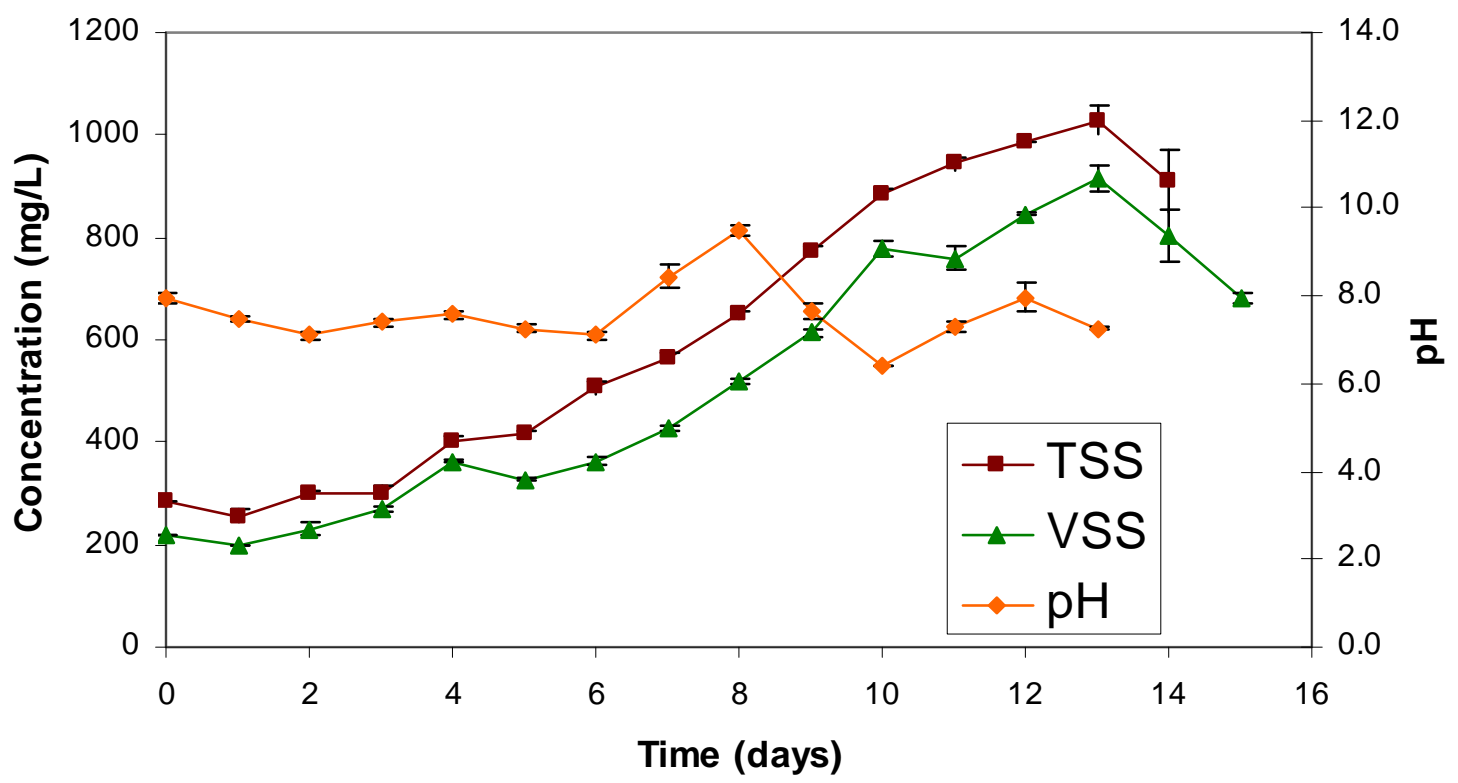

Figure 4.9 Biomass and pH for batch experiment for $25 \%$ WW dilution. 


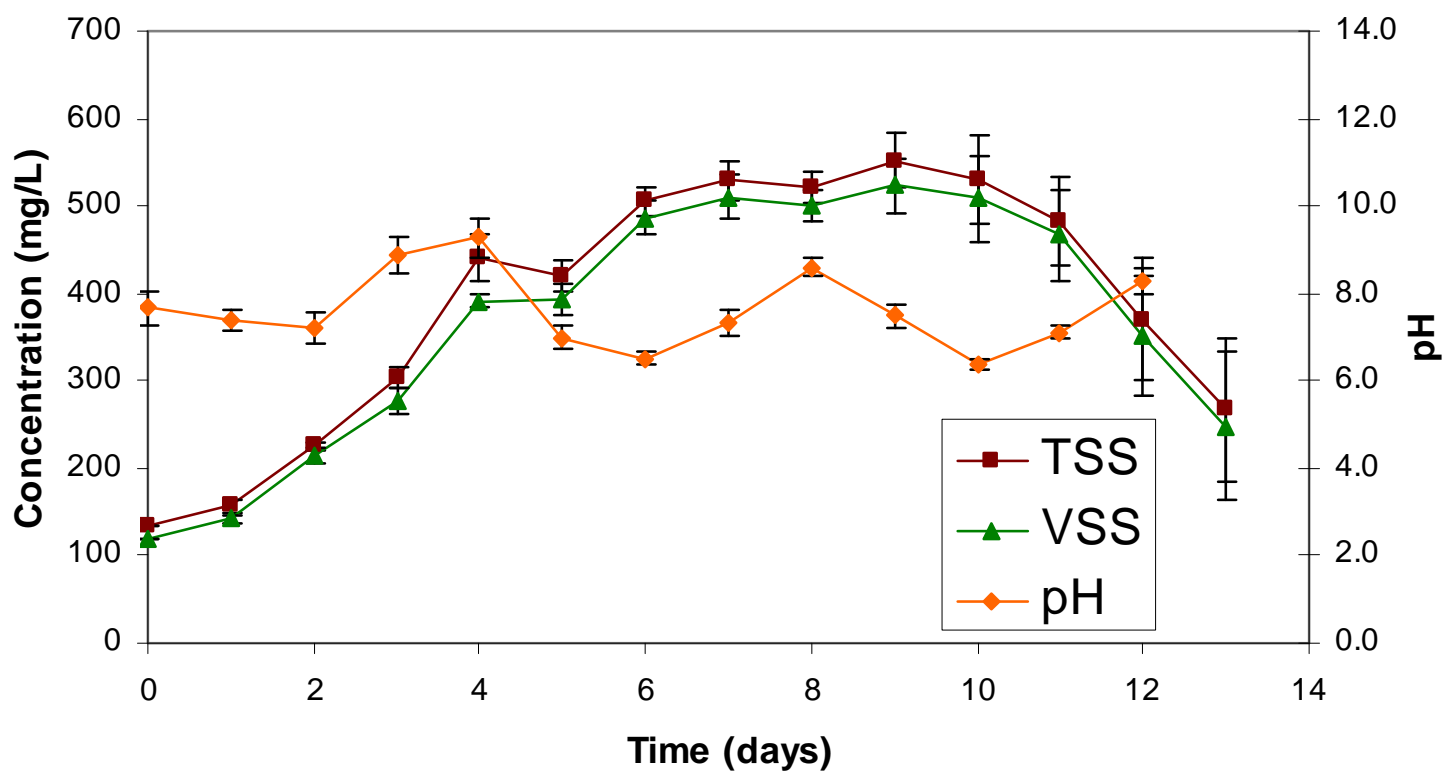

Figure 4.10 Biomass and $\mathrm{pH}$ for batch experiment for $25 \% \mathrm{WW}$ dilution.

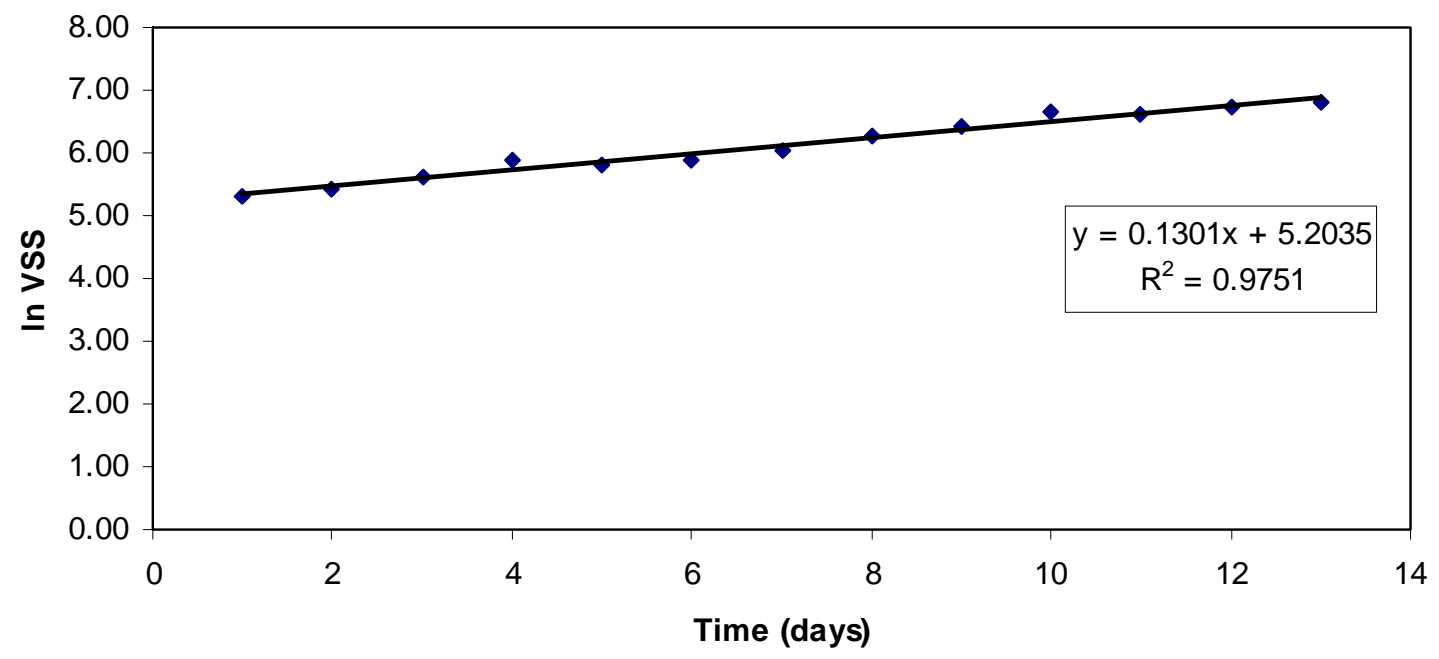

Figure 4.11 Log phase of biomass for $25 \% \mathrm{WW}$ dilution algae growth reactor 


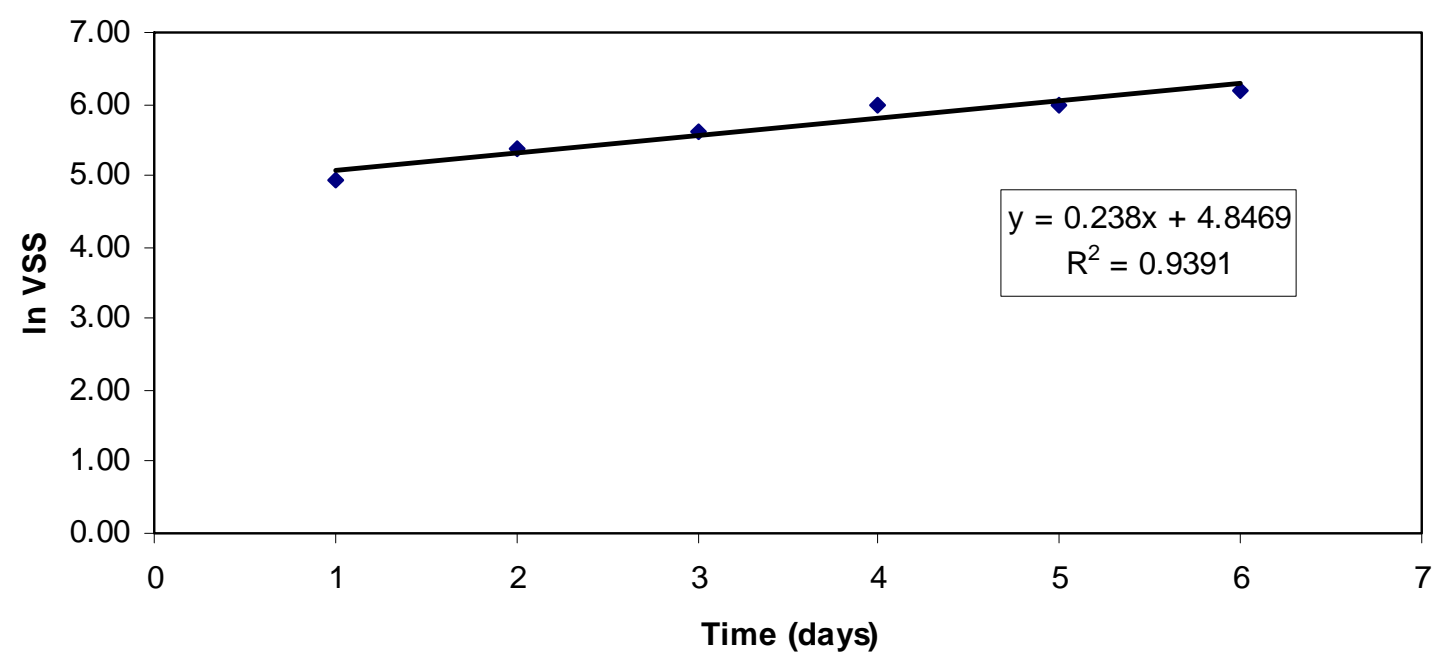

Figure 4.12 Log phase of biomass for $10 \% \mathrm{WW}$ dilution algae growth reactor

\subsubsection{Total Lipid Percentages and Productivity}

The total lipid concentrations were measured throughout the batch experiment to determine productivity of lipids. The total lipid content of biomass from the $10 \%$ wastewater dilution ranged from $8-14 \%$, and the lipid content of biomass grown in the $25 \%$ dilution of wastewater ranged from 10-29\%, by weight (Figure 4.13 and Figure 4.14). The highest oil percentage was observed in the middle of the exponential growth phase for both the $10 \%$ and $25 \%$ dilution wastewater experiments (Figure 4.13 and Figure 4.14). 5\% of the samples were spiked with a known weight of canola triglycerides and had an average recovery of $84 \%$.

The lipid content of the algae in this experiment compare favorably to values reported in the literature. Total lipid percentages have been reported as high as $45 \%$ for pure cultures of Scenedesmus and Chlorella by Thompson (1996). It is remarkable that this experiment was able to achieve such high lipid percentages (29\%) without optimization 
of the algal cultures or the operating conditions. This result suggests that even higher lipid percentages could be achieved in the wastewater treatment application with optimization. 


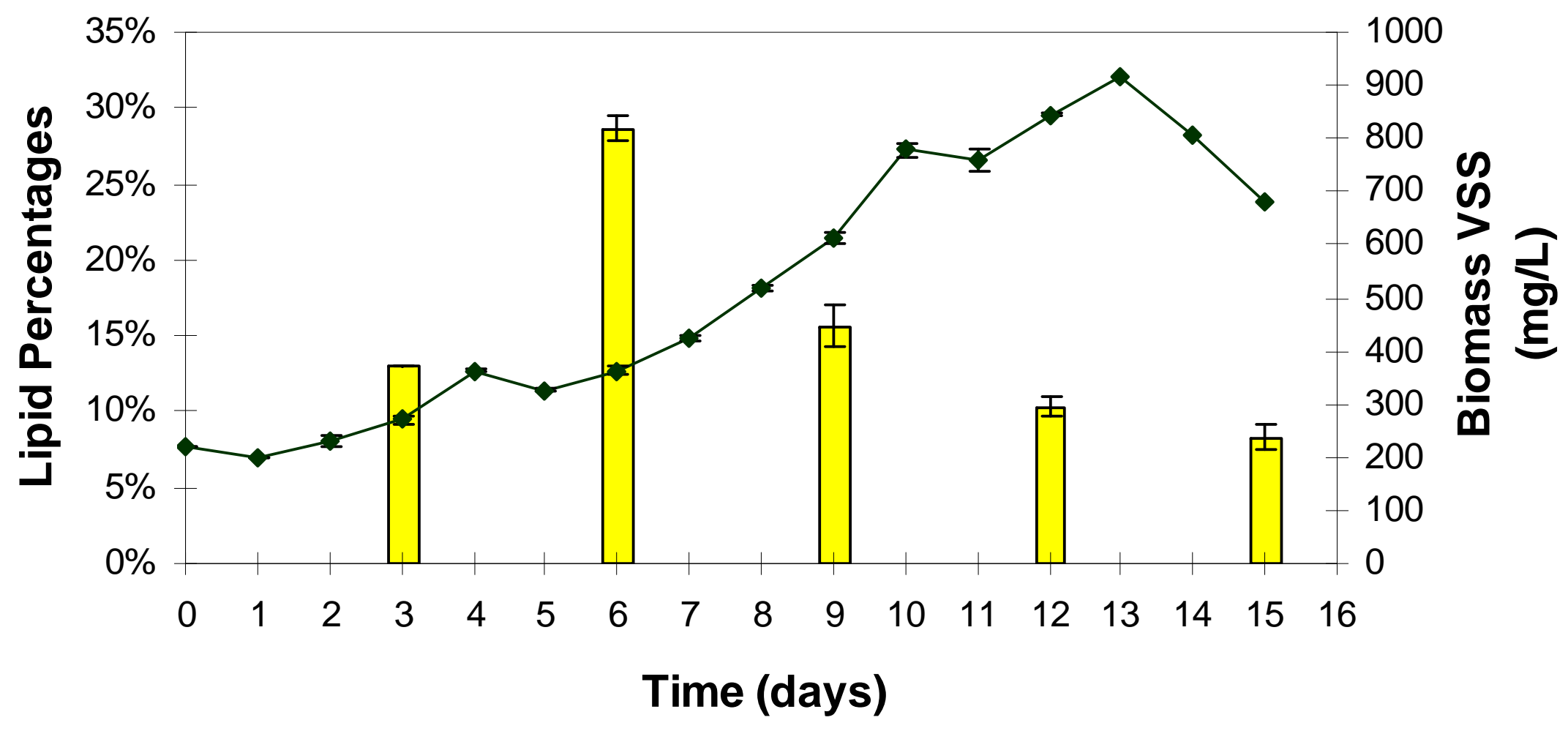

\section{Lipids Percentage $\rightarrow$ - Biomass VSS (mg/L)}

Figure 4.13: 25\% WW Dilution algae growth and lipid content during batch run. (Averages from triplicate batch reactors are shown with error bars indicating standard deviation.) 


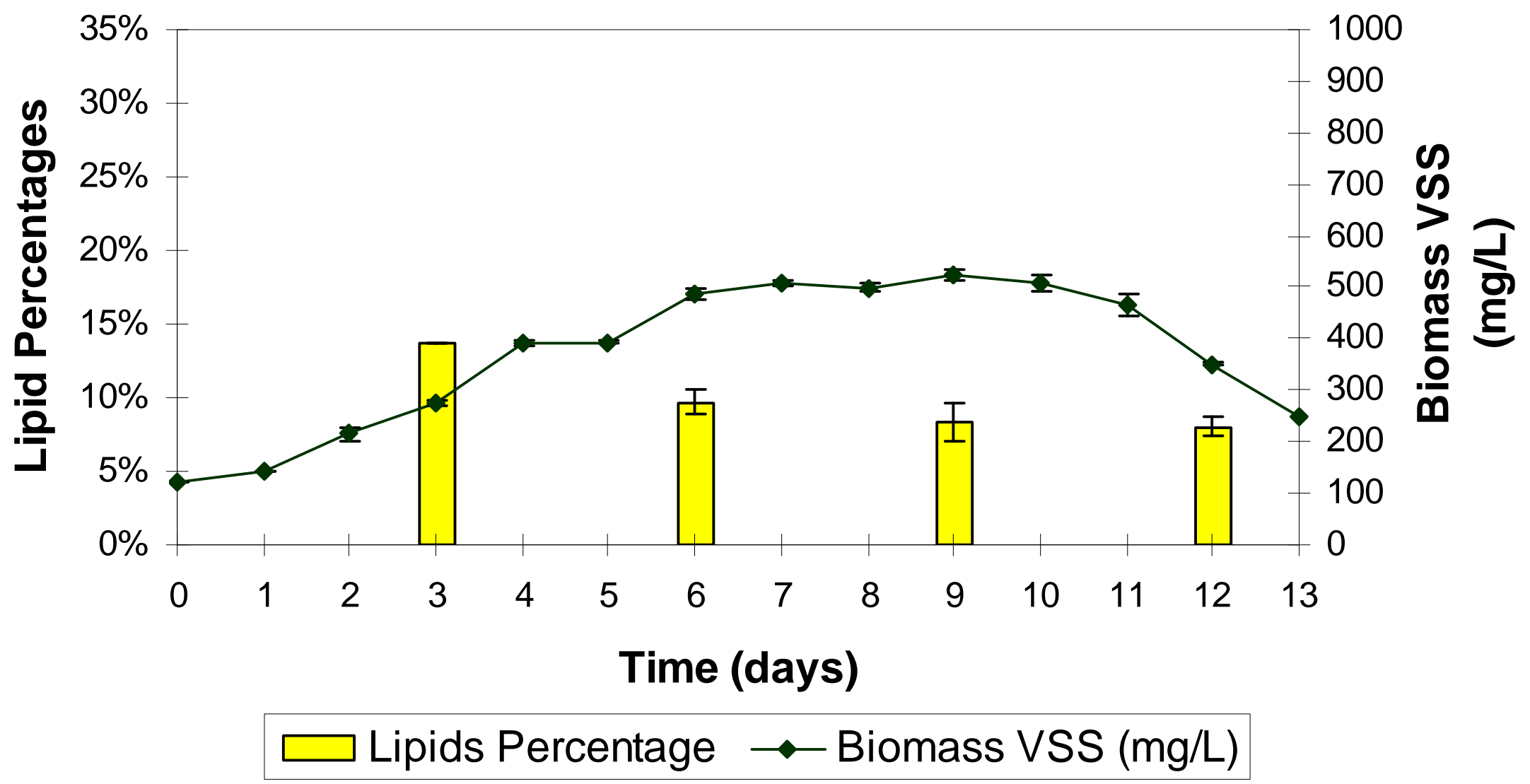

Figure 4.14: 10\% WW Dilution algae growth and lipid content during batch run. (Averages from triplicate batch reactors are shown with error bars indicating standard deviation.) 
Based on the results for the lipid extraction and the surface area of the algae bioreactor, the maximum production rate of lipids of $2.8 \mathrm{~g} / \mathrm{m}^{2} /$ day was reached at Day 6 for the $25 \%$ wastewater dilution, and $2.0 \mathrm{~g} / \mathrm{m}^{2} /$ day was reached at Day 3 for the $10 \%$ wastewater dilution. Somewhat higher productivities have been found in open systems using pure cultures (Table 4.3). Laws (1984) found that a pure culture of Platymonas sp. had a lipid productivity of $7.9 \mathrm{~g} / \mathrm{m}^{2} /$ day, Thomas et al. (1984) through the NREL study found that a pure culture of Tetraselmis suecica had a lipid productivity of $4.5 \mathrm{~g} / \mathrm{m}^{2} /$ day, and Brown et al. (1990) found that a pure culture of Cyclotella cryptica had a maximum lipid productivity of $4 \mathrm{~g} / \mathrm{m}^{2} /$ day.

Table 4.3: Lipid productivity of algae reported in the literature

\begin{tabular}{lcccl}
\hline Study & $\begin{array}{c}\text { Lipid } \\
\text { productivity } \\
(\mathbf{g} / \mathbf{m} \text { /d) })\end{array}$ & Algal Species & $\begin{array}{c}\text { Growth } \\
\text { vessel }\end{array}$ & Media \\
\hline Laws (1984) & 7.9 & Platymonas sp. & Air lift flume & Sea water \\
Thomas (1984) NREL & 4.5 & Tetraselmis suecica & Indoor reactor & Nutrient enriched seawater \\
Brown (1990) & 4 & Cylcotella cryptica & Open pond & Si defficient media \\
This study & 2.8 & Mixed & Open reactor & Anaerobic treated dairy wastewater \\
\hline
\end{tabular}

In both batch experiments the highest lipid percentages were achieved in the early part of the growth phase, which may suggest that lipids were produced as a growth-associated product. Roessler (1990) has discussed similar results of increased lipid percentage in the exponential growth phase of microalgae and theorized that at lower biomass concentrations, where light is at a higher intensity, algae biosynthesize lipids as a means of converting excess light into reserve energy in the form of lipids. 
Using the maximum observed lipid productivity for a scale up to a high-rate algae pond suggests that the maximum potential lipid productivity is 1,200 gallons/acre/year based on the surface area of the algae bioreactor. Major assumptions for this calculation include the lipid density of $0.926 \mathrm{~kg} / \mathrm{L}$ and a continuous production 365 days per year ignoring weather fluctuations and down time. If the depth was increased to 0.3 meters, which is typical of such systems, and maintained at the same biomass concentrations, the potential lipid productivity could increase to 2,200 gallons/acre/year. The actual productivity for a full-scale system will depend of course on environmental conditions. It is significant to note that the estimated oil production of 2,200 gal/acre/year is 45 times more productive than the 48 gal/acre/yr reported for conventional soybeans (Pimentel and Patzek, 2005).

\subsubsection{Nutrient Removal}

Removal of $\mathrm{N}$ and $\mathrm{P}$ nutrients from the dairy wastewater was rapid in the algae bioreactors (Figure 4.15 and Figure 4.16). For the $25 \%$ dilution reactors, initial concentrations of ammonia $\left(\mathrm{NH}_{3}\right)$ were $30 \mathrm{mg} / \mathrm{L}$ and were reduced to below $5 \mathrm{mg} / \mathrm{L} \mathrm{NH}_{3}$ (as $\mathrm{N}$ ) in 6 days. The initial phosphate $\left(\mathrm{PO}_{4}{ }^{3-}\right)$ concentration of $2.5 \mathrm{mg} / \mathrm{L}$ (as $\mathrm{P}$ ) was reduced to $0.6 \mathrm{mg} / \mathrm{L} \mathrm{PO}_{4}$ (as $\mathrm{P}$ ) in 9 days and completely removed by Day 12 . Nitrate concentrations for both the $25 \%$ and $10 \%$ dilution reactors were consistently below 0.3 $\mathrm{mg} / \mathrm{L}$, and final nitrate concentrations were below the detection limit of $0.02 \mathrm{mg} / \mathrm{L} \mathrm{NO}_{3}$ (as N) (Figure 4.15 and Figure 4.16). Nitrite showed a slight increase at Day 6 up to 0.5 $\mathrm{mg} / \mathrm{L} \mathrm{NO}_{2-}$ (as $\left.\mathrm{N}\right)$ suggesting some possible nitrification or denitrification. 


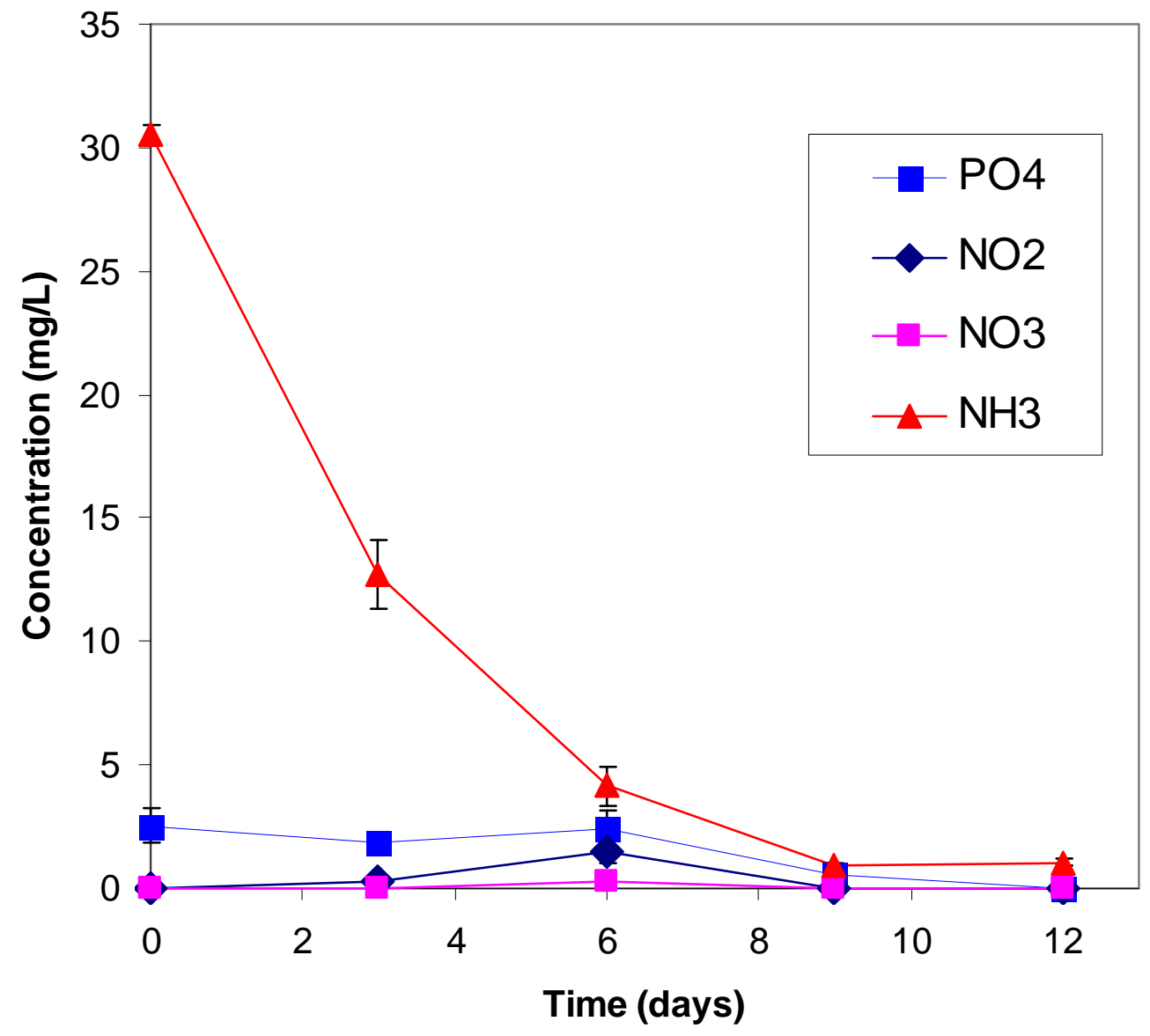

Figure 4.15: Nutrient reduction in $25 \%$ dilution culture.

For the $10 \%$ dilution reactor, nutrient removal was also rapid (Figure 4.16). The initial concentration of ammonia $\left(\mathrm{NH}_{3}\right)$ was $16.3 \mathrm{mg} / \mathrm{L}$ and was reduced to less than $1 \mathrm{mg} / \mathrm{L}$ $\mathrm{NH}_{3}$ (as $\left.\mathrm{N}\right)$ in 3 days. The initial phosphate $\left(\mathrm{PO}_{4}{ }^{3-}\right)$ concentration of $1.8 \mathrm{mg} / \mathrm{L}$ was reduced below detection limits in 9 days. 


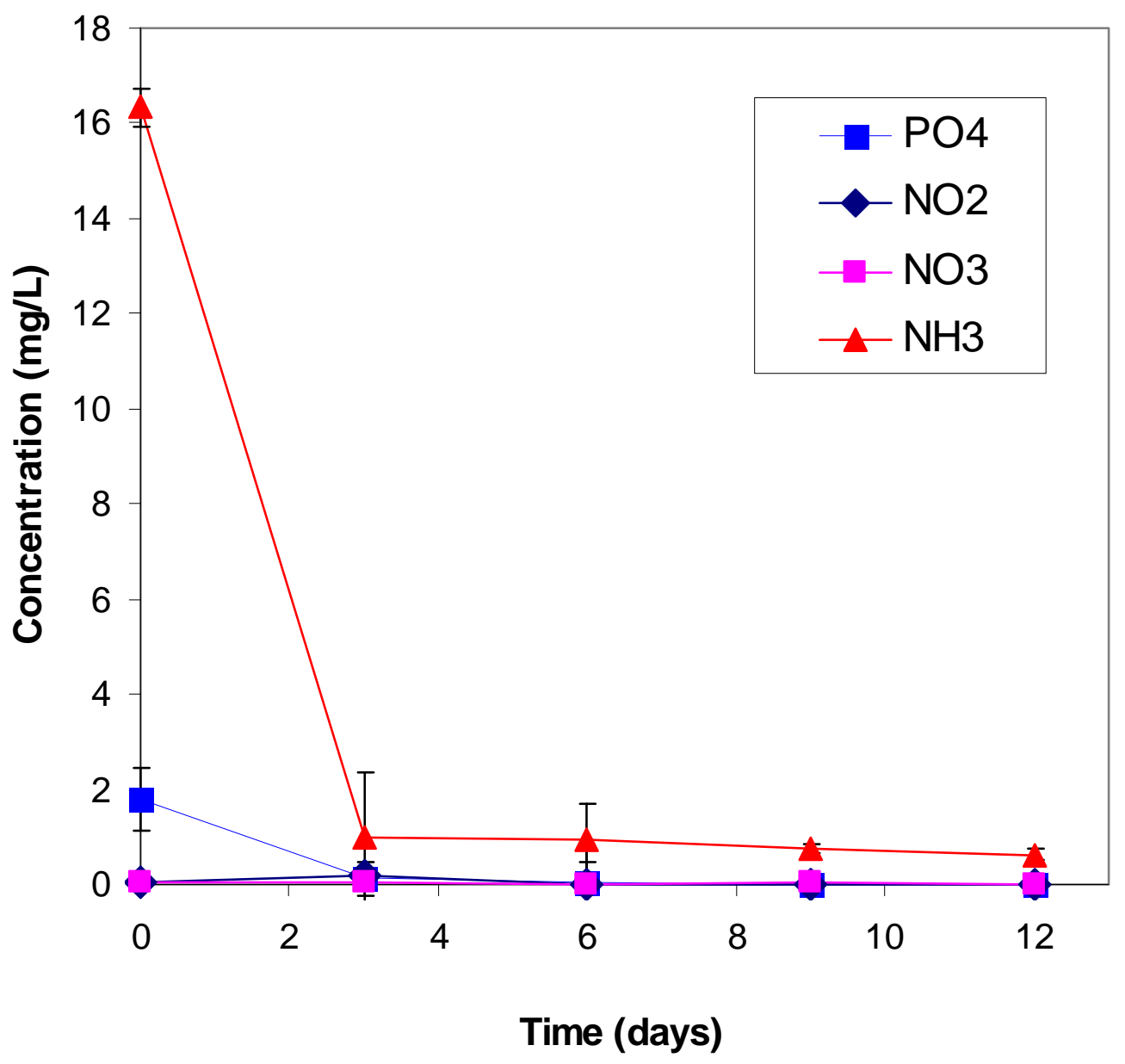

Figure 4.16: Nutrient reduction in $10 \%$ dilution culture.

The ammonia removal efficiency observed in this experiment is comparable to other algae based treatments systems (Table 4.4). Previous studies have shown that algae is very effective (80-100\%) in the removal of $\mathrm{NH}_{3}$ (as $\mathrm{N}$ ) from a variety of wastewaters (Martinez et al., 2000, Lincoln et al., 1996, Green et al., 1995). 
Table 4.4: Ammonia removal comparison for algae treatment systems

\begin{tabular}{lcll}
\hline \multicolumn{1}{c}{ Study } & $\begin{array}{c}\text { \% NH3-N } \\
\text { Removal }\end{array}$ & \multicolumn{1}{c}{ Algae Species } & \multicolumn{1}{c}{ Media } \\
\hline Martinez (2000) & $80-100$ & Scenedemus obliques & Autoclaved municipal wastewater \\
Lincoln (1996) & 99 & Arthrouspira plantensis & Anaerobic treated dairy wastewater \\
Green (1995) & 99 & Mixed culture & Municipal wastewater \\
This study & 96 & Mixed culture & Anaerobic treated dairy wastewater \\
\hline
\end{tabular}

A nitrogen balance was conducted to determine the fate of the different species of nitrogen (Table 4.5). The nitrogen balance includes nitrogen as ammonia or ammonium $\left(\mathrm{NH}_{\mathrm{x}}\right)$, nitrite $\left(\mathrm{NO}_{2}^{-}\right)$, nitrate $\left(\mathrm{NO}_{3}{ }^{-}\right)$, organic nitrogen $(\mathrm{ON})$, total Kjeldahl nitrogen (TKN), and total nitrogen (TN). Organic nitrogen measurements include the nitrogen that was assimilated by the algae. Organic nitrogen was calculated by subtracting the $\mathrm{NH}_{\mathrm{x}}$ from the TKN. Total nitrogen is the sum of TKN, $\mathrm{NO}_{2}^{-}$, and $\mathrm{NO}_{3}^{-}$. There was a reduction in total nitrogen from $81 \mathrm{mg} / \mathrm{L}$ to $56 \mathrm{mg} / \mathrm{L}$ in the $25 \%$ dilution and a reduction from $37 \mathrm{mg} / \mathrm{L}$ to $15 \mathrm{mg} / \mathrm{L}$ for $10 \%$ dilution (Table 4.5 ). There was only a slight increase in organic nitrogen of $4 \mathrm{mg} / \mathrm{L}$ (as N) from the initial (Day 0) to the final (Day 15) for the $25 \%$ dilution. A higher concentration of organic nitrogen was expected as the result of algae growth. There was a decrease in organic nitrogen in the $10 \%$ dilution observed. There are two probable explanations for the loss or lack of increase in ON: (1) the initial ON was high and composed of waste solids that were replaced by algae ON, and (2) the reduction in total nitrogen suggests that not all of the nitrogen was assimilated by the algae or bacteria present in the bioreactors and that there was volatilization of nitrogen either as $\mathrm{NH}_{3}$ or as $\mathrm{N}_{2}$ resulting from denitrification. 
In future testing it would be advantageous to sample for TKN throughout the experiment to provide a more thorough picture of the nitrogen fate.

\section{Table 4.5: Nitrogen balance for all species of $\mathbf{N}$}

\begin{tabular}{|c|c|c|c|c|c|c|c|c|c|c|c|c|}
\hline & \multicolumn{6}{|c|}{ 10\% Dilution } & \multicolumn{6}{|c|}{ 25\% Dilution } \\
\hline & $\mathrm{NH}_{\mathrm{x}}$ & $\mathrm{NO}_{2}$ & $\mathrm{NO}_{3}$ & ON & TKN & TN & $\mathrm{NH}_{\mathrm{x}}$ & $\mathrm{NO}_{2}$ & $\mathrm{NO}_{3}$ & ON & TKN & TN \\
\hline Initial (Day 0) & 16.33 & 0.04 & 0.05 & 20.20 & 36.53 & 36.61 & 30.50 & 0.00 & 0.01 & 50.69 & 80.99 & 80.99 \\
\hline Final (Day 15) & 0.63 & 0.00 & 0.02 & 14.15 & 14.77 & 14.79 & 1.07 & 0.00 & 0.01 & 54.59 & 55.69 & 55.69 \\
\hline
\end{tabular}

\subsubsection{Dissolved Oxygen and $\mathrm{pH}$ Changes During Batch Experiments}

Dissolved oxygen concentrations in the both $10 \%$ and $25 \%$ dilution bioreactors were measured over time to observe diurnal effects on dissolved oxygen. Results show an accelerated increase in dissolved oxygen during sunrise at approximately 6:45 am (Figure 4.17 and Figure 4.18). $\mathrm{pH}$ decreased during the pre-dawn to late morning period. $\mathrm{A} \mathrm{pH}$ rise would be expected due to increased photosynthesis, but apparently the media were buffered well enough to mask this effect in the early hours of the day. 


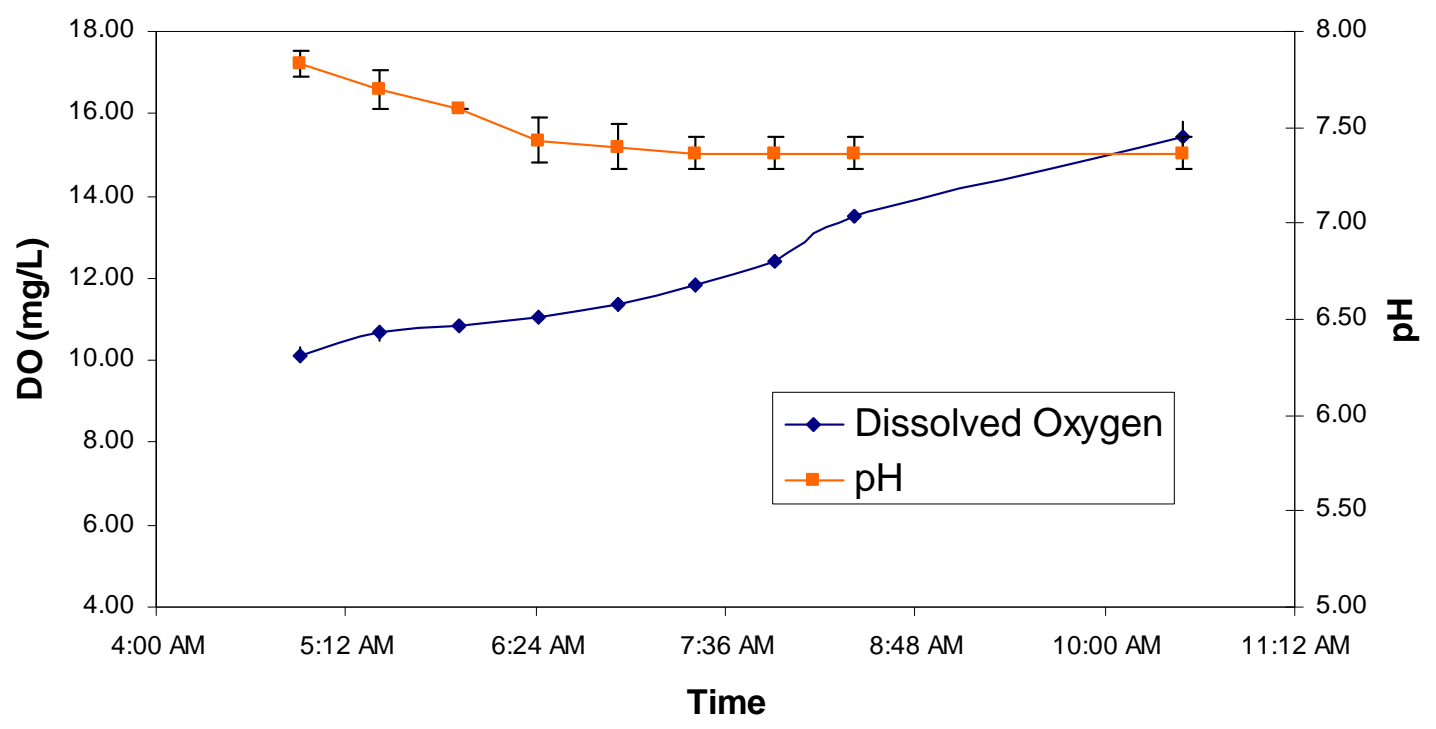

Figure 4.17: Dissolved oxygen and $\mathrm{pH}$ change in $25 \%$ dilution culture through sunrise on March $24^{\text {th }}, 2007$

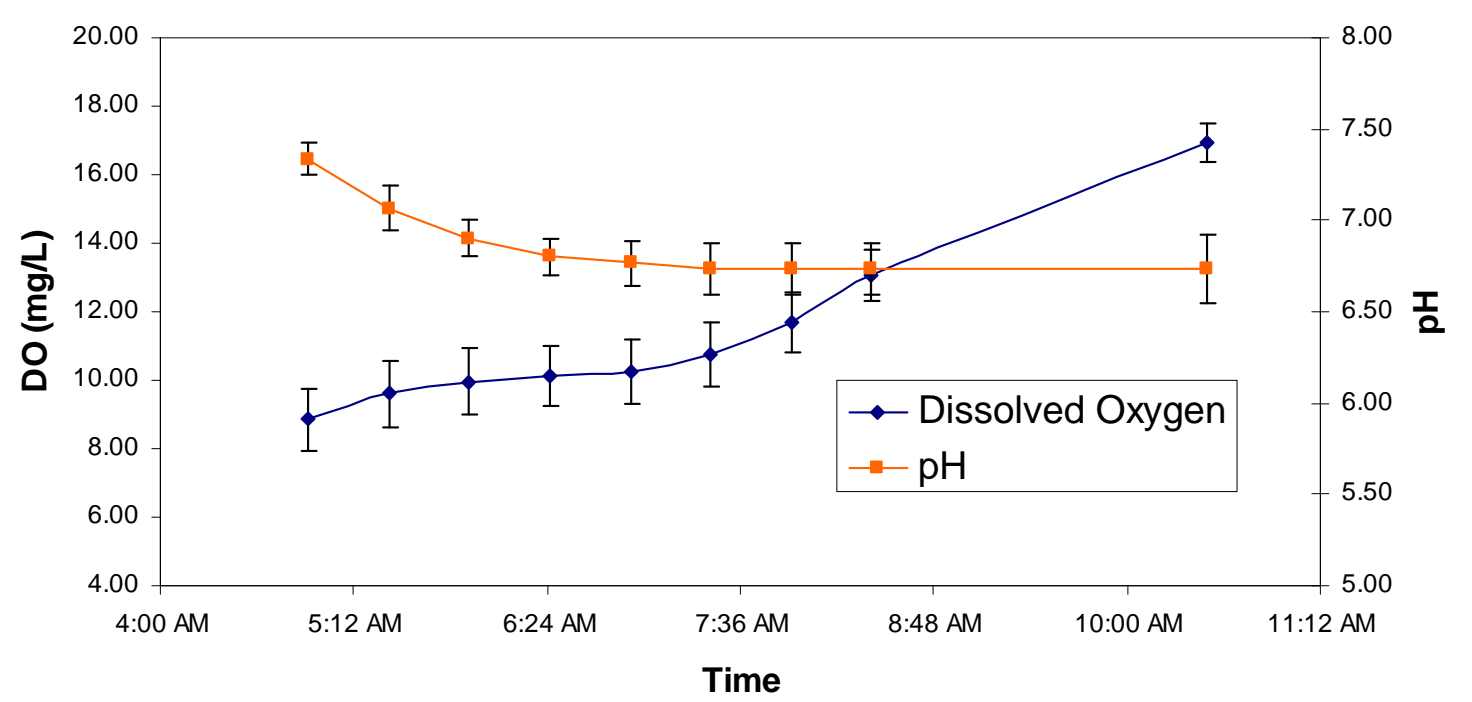

Figure 4.18: Dissolved oxygen and pH change in $10 \%$ dilution culture through sunrise March $24^{\text {th }}, 2007$. 


\section{CHAPTER 5: CONCLUSIONS}

\subsection{Experimental Conclusions}

The oil productivity of the mixed species of algae observed in the bench-scale bioreactors is significantly higher than that of terrestrial crops. When scaled up, the expected production rate is between 1,200 and 2,200 gal/acre/year, assuming the same environmental conditions as those in the experiments year round. In comparison, soy can currently produce $48 \mathrm{gal} / \mathrm{acre} / \mathrm{year}$ (Pimental and Patzek, 2005). Thus, production of biodiesel from algae is 45 times more efficient than from soy, based on area of land used. Previous NREL studies demonstrated biodiesel production rates of 1,900 gal/acre/year using pure cultures of high-yield algae grown under controlled conditions (Thompson, 1996). It is remarkable that similar production efficiencies were observed in this project with mixed cultures of native algae grown on dairy wastewater under relatively uncontrolled conditions.

To put the bench-scale results of lipid productivity into perspective, if all of the 50 billion gallons of U.S. diesel fuel that is consumed annually were to come from algal oil, at productivity of 1,200 gal/acre/yr it would take a total area of 43 million acres or the equivalent size of Tennessee. However, the large scale implementation of algal ponds will not be concentrated in one location. Algae ponds will be have to be decentralized to utilize wastewater from agricultural operations and municipalities.

The bench-scale experiments also demonstrated the effectiveness of algae at nutrient removal from wastewater by reducing the total ammonia-N concentrations from $30 \mathrm{mg} / \mathrm{L}$ 
(as $\mathrm{N}$ ) to below $1 \mathrm{mg} / \mathrm{L}$ (as $\mathrm{N}$ ) and removing phosphate with nearly $100 \%$ efficiency in 9 days from $2.55 \mathrm{mg} / \mathrm{L}$ (as $\mathrm{P}$ ) to $<0.1 \mathrm{mg} / \mathrm{L}$ (as $\mathrm{P}$ ). This utilization of nutrients from wastewater demonstrates the potential cost savings when compared to the purchase of fertilizers. The large uptake of nutrients by biomass also indicates that the biomass debris left after oil extraction will have potential as crop fertilizer.

This thesis provided a large step towards creating biodiesel fuel from algae by demonstrating high productivities and excellent nutrient removal. However, there are a few things that could have made this thesis more definitive. Instead of performing the semi-continuous experiments first and the batch experiments second it would have been advantageous to use the batch experiments first to allow an optimization of lipid productivity during a semi-continuous experiment. In addition, to validate the annual lipid productivity a year round study should be performed to account for seasonal changes.

In conclusion biodiesel can be an important part in our nation's solution to global warming and energy independence. However, it is not the only solution and unsustainable crop production threatens to generate even more pollution. The use of algae as a feedstock for biodiesel greatly increases the yields that can be achieved. Further, through simultaneous wastewater treatment and biofuel production a more sustainable model can be achieved. 
It should be noted that the greatest strategy for reducing greenhouse gases and creating energy independence is not simply to replace our petroleum consumption with biofuels consumption, but to conserve and improve efficiencies of energy usage and production. Biofuels, produced properly, can help contribute to creating a sustainable and energy independent society.

\subsection{Future Research}

There are still many hurdles that must be overcome before the proposed system can be operated economically on full-scale. The lipid composition of algal lipids should be investigated as well as developing passive harvesting techniques. There is also the need to demonstrate pilot scale testing with optimization of growth conditions in a year round study. In addition, an analysis of potential climate and location restrictions will be needed to understand the large-scale implementation potential.

Further study is needed in the classification of the lipids that are found in algae grown in wastewater. The experiments conducted here only looked at total lipid content. It will be necessary to determine the lipid structure derived from waste-grown algae to determine the direct fuel quality that would be achieved. The quality of oil produced from algae will affect the value of the final product and the processing required to create a transportation fuel. The oil produced from algae grown in wastewater might not be suitable for traditional biodiesel processing (transesterification). In addition to multiple algae species present there is also the presence of bacteria which may have oil that is not preferable for biodiesel production. The oil might be more compatible with newer 
technologies such as renewable diesel (thermal depolymerization) which processes the oil in a similar fashion as petroleum. In future experiments, the lipids extracted from the algal biomass should be analyzed by mass spectrometry to identify the fatty-acid composition and the degree of unsaturation.

The harvesting and processing of the algae will be major inputs into the practicality of this technology. The use of forced separation (centrifugation) is a highly energyintensive process and greatly affects the energy balance of the biofuel. More passive systems of harvesting such as natural settling by use of a return activated sludge bioflocculation technique is currently being investigated by fellow Cal Poly graduate student Dan Frost. In this method algae growth tanks are inoculated with developed bioflocculations of return activated sludge (RAS). The developed bioflocculations enhance the settling of the algae that are present. Variations of the activated sludge flocculation technique such as "activated algae" should be investigated because RAS may not be available for certain situations.

Pilot-scale systems should be investigated into how the performance of algae production and lipid productivities are affected by scale-up. There are no known studies of open wastewater ponds where $\mathrm{CO}_{2}$ is added to enhance algae productivities. Research has been conducted in lab by fellow Cal Poly graduate student Adam Feffer into the effect of $\mathrm{CO}_{2}$ addition in municipal wastewater (Feffer, 2007). Following pilot scale experiments it would be necessary to create a prototype system with the integration of an anaerobic digester and co-generation system. 
During the development of this technology it will be imperative to determine the potential for implementation of the proposed system on a wide-scale. The largest obstacle in the implementation of this will be location. An analysis will be required to determine how many communities and agro-industrial sites, in appropriate climates (average temperature and solar insolation), have the need for wastewater treatment upgrades. In addition, there would be the need to have information about the land available for large open ponds at each of these locations. Furthermore, once algae biomass is being produced in large quantities the conversion to useful biofuel will require further processing which might be most cost-effective offsite. The extraction of lipids from the algae will probably be done with solvent extractions that would be carried out by production facilities already in use for oil seed extraction. The location proximities of algae production to oil extraction plants as well as biodiesel production sites will need to be analyzed.

Another consideration is the value of $\mathrm{CO}_{2}$ fixation. $\mathrm{CO}_{2}$ credits are still being developed and standardized but the ultimate value will have a large impact on the economic value of the proposed system. 


\section{REFERENCES}

Adler, P.R., Del Grosso, S.J., Parton, W.J., (2007) "Life-cycle assessment of net greenhouse-gas flux for bioenergy cropping systems." Ecological Applications: 17:3 pp. 675-691.

American Public Health Association, (1995) Standard Methods for the Examination of Water and Wastewater. American Public Health Association Washington, DC.

An, J.Y., Sim, S.J., Lee, J.S., Kim, B., (2003) "Hydrocarbon production from secondary treated piggery wastewater by the green alga Botryococcus braunii." Journal of Applied Phycology 15: pp. 185-191.

Anderson, R.A. (2005) Algal Culturing Techniques Phycological Society of America Elsevier Inc.

Benemann, J.R., (2007) "Biofuel, Peak Oil, and Global Warming 1977-2037"

Presentation at California Polytechnic State University, San Luis Obispo, 1-18-07.

Benemann, J., Goebel, P., Weissman, J., Augenstein, D., (1982) "Microalgae as a source of liquid fuels. Final technical report." USDOE-OER.

http://www.osti.gov/bridge/product.biblio.jsp?query id=0\&page=0\&osti id=6374113.

Benemann, J.R., Tillett, D.M., (1987) "Microalgae lipid production” In Energy from Biomass and Waste XI, Conference Proceding, (Klass, D.L., ed), Institute of Gas Technology, Chicago.

Bligh, E.G., Dyer, W.J., (1959) "Extraction of Lipids in Solution by the Method of Bligh and Dyer" Canadian Journal of Biochemical Physiology. 37: pp. 911-917.

Brown, L.M., Sprague, S., (1990) "Aquatic Species Project Report FY 1989-90" NREL/TP-232-4174 DE92001207 Report by Weissman, J.C., Tillet, D., "Design and Operation of an Outdoor microalgae test facility: Large scale system results.

California Water Board, (2003) Nonpoint Source Pollution, Agricultural Category FiveYear Implementation Plan.

http://www.waterboards.ca.gov/nps/docs/5yrplan/2_agri_category.pdf.

Centner, T.J., (2001) "Evolving Policies to Regulate Pollution from Animal Feeding Operations" Environmental Management. 28:5 pp. 599-609.

Chisti, Y., (2007) "Biodiesel from Microalgae” Biotechnology Advances 25: pp. 294-306.

Chisti, Y., Molina, E., Feranadez, J., Acien, F.G., (2001) "Tubular photobioreactor design for algal cultures" Journal of biotechnology: 92: pp 113-131. 
Christie, W., (2003) Lipid Analysis, Isolation, Separation, Identification and Structural Analysis of Lipids $3^{\text {rd }}$ Edition The Oily Press, PJ Barnes and Associates, England.

Duffield, J.A., (2007) U.S. Department of Agriculture Office of Energy Policy and New Uses Proceedings from National Biodiesel Conference, San Antonio, TX Feb 4-8, 2007.

Dugan, G.L., Golueke, C.G., Oswald, W.J., (1972) "Recycle system for poultry waste" Journal Water Pollution Control Federation 44(3): 432.

Energy Information Agency (2005) Annual Energy Review Report No. DOE/EIA0384(2005). http://www.eia.doe.gov/.

Feffer, A.S. (2007). The Effects of CO2 Addition on Algae Wastewater Treatment, M.S. thesis, Department of Civil and Environmental Engineering, California Polytechnic State University, San Luis Obispo.

Glastra, R., (2002), Oil Palm Plantations and deforestation in Indonesia, assets.panda.org/downloads/oilpalmindonesia.pdf.

Golueke, C.G., Oswald, W.J., Gotaas, H.B. (1957) “Anaerobic digestion of algae” Applied Microbiology 5(1): pp. 47-55.

Green, F.B., Bernstone, L.S., Lundquist, T.J., Oswald, W.J., (1996) “Advanced Integrated Wastewater Pond Systems for Nitrogen Removal.” Wat. Sci. Tech. 33:7 pp. 207-217.

Green, F.B., Lundquist, T.J., Oswald, W.J., (1995). "Energetics of advanced integrated wastewater pond systems," Water Science and Technology: 31:12, pp. 9-20.

Haas, M.J., Scott, K.M., Alleman, T.L., McCormick, R.L., (2001) “Engine Performance of Biodiesel Fuel Prepared from Soybean Soapstock: A High Quality Renewable Fuel Produced from Waste Feedstock" Energy and Fuels: 15: pp 1207-1212.

Intergovernmental Panel on Climate Change (2007) "IPCC Summary for Policymakers. In: Climate Change 2007: The Physical Science Basis. Contribution of Working Group I to the Fourth Assessment Report of the Intergovernmental Panel on Climate Change, Solomon, S., D. Qin, M. Manning, Z. Chen, M. Marquis, K.B. Averyt, M. Tignor and H.L. Miller. Cambridge University Press, Cambridge, United Kingdom and New York, NY, USA.

Landis, A. E., Miller, S. A, Theis, T.L., (2007) "Life Cycle of the Corn-Soybean Agroecosystem for Biobased Production.” Environ. Sci. Technol.: 41, 1457-1664. 
Laws, E. (1984) "Research and Development of Shallow Algal Mass Culture Systems for the Production of Oils" Solar Energy Research Institute, Subcontract No. XK-3-03136 report.

Lincoln, E.P., Wilkie, A.C., French, B.T., (1996) “Cyanobacterial process for renovating dairy wastewater" Biomass and Bioenergy” 10:(1) pp. 63-68.

Lundquist, T., Benemann, J., Feffer, A., Woertz, I., (2007) "Presentation on Nutrient Removal and Biofuel Production through Microalgae-Based Wastewater Treatment" First Western Forum on Energy \& Water Sustainability University of California Santa Barbara March 22-23, 2007.

Matinez, M.E., Sanchez, S., Jimenez, J.M. El Yousfi, F., Munoz, L., (2000) "Nitrogen and phosphorus removal from urban wastewater by the microalga Scenedesmus obliquus" Bioresource Technology 73: pp. 263-272.

Metcalf and Eddy, Tchobanoglous, G., Burton, F.L., Stensel, H.D., (2003) Wastewater Engineering: Treatment and Reuse. $4^{\text {th }}$ Eddition. McGraw HIl ISBN-13: 978-0-07041878-3.

Mulbry, W., Westhead, E.K., Pizarro, C., Sikora, L., (2005) "Recycling of manure nutrients: use of algal biomass from dairy manure treatment as a slow release fertilizer" Bioresource Technology 96 pp. 451-458.

National Biodiesel Board, NBB website (retrieved October 2007). www.biodiesel.org.

National Research Council, (2007) Committee on Water Implications of Biofuels Production in the United States, "Water Implication of Biofuels Production in the United States" National Academies Press http://www.nap.edu/catalog/12039.html.

Ono, E., Cuello, J. (2004) "Development of Microalgal $\mathrm{CO}_{2}$ Biofixation Photobioreactor" The Canadian Soc. For Eng and Ag Food, and Bio Sci Paper \# 044103.

Oswald, W.J., (Feb 1962) "The Coming Industry of Controlled Photosynthesis" American Journal of Public Health 52:2.

Oswald, W.J., (2003) "My sixty years in applied algology" Journal of Applied Phycology 15: pp. 99-106.

Oswald, W.J., Gotaas, H.B. (1957) "Photosynthesis in Sewage Treatment" Paper presented before the Sanitary Engineering Division, American Society of Civil Engineers, New York, N.Y., (October 1954). Reprinted in Transactions of the American Society of Civil engineers, Volume 122, (1957). 
Oswald, W.J., Gotaas, H.B., Ludwig, H.F., Lynch, V. (1953) "Algae Symbiosis in Oxidation Ponds. Photosynthetic Oxygenation" Sewage and Industrial Wastes 25(6): pp. 692-705.

Patzek, T., and Pimentel, D., (September, 2005), "Is Ethanol from Veggies a Waste of Fossil Energy Sources", Natural Resources Research: 163, Issue 9, pp.84-85.

Pimentel, D., and Patzek, T.W., (March, 2005) "Ethanol Production Using Corn, Switchgrass, and Wood; Biodiesel Production Using Soybean and Sunflower." Journal of Natural Resources Research: 14:1 pp. 65-76.

Roessler, P., (1990) "Environmental control of glycerolipid metabolism in microalgae: commercial implications and future research directions" Journal of Phycology 26: pp. 393-399.

Sheehan, J., Dunahay, T., Benemann, J., Roessler, P., (1998) “A Look Back at the U.S. Department of Energy's Aquatic Species Program-Biodiesel from Algae" National Renewable Energy Program.

Shelef, G. (1968). Kinetics of algal biomass production systems with respect to light intensity and nitrogen concentration. Engineering. Berkeley, University of California, Berkeley.

Spolaore, P., Joannis-Cassan, C., Duran, E., Isambert, A., (2006) "Review: Comercial Applications of Microalgae" Journal of Bioscience and Bioengineering: 101:2 pp 87-96.

Talens, L., Villalba, G., Gabarell, X., (2007) "Exergy analysis applied to biodiesel production" Resources, Conservation and Recycling 51: pp. 397-407.

Thomas, W.H., Seibert, D.L.R., Aldem, M., Neori, A., Eldridge, P., (1984) "Yields, photosynthetic efficiency, and proximate composition of dense marine microalgal cultures. II Dunaliella primolecta and Tetraselmis suecica experiments.” Biomass 5: pp 211-225.

Thompson, G.A., (1996) "Lipids and membrane function in green algae" Biochemica et Biophysica 1306: pp. 17-45.

Tickell, J., (2006) Biodiesel America: How to Achieve Energy Security, Free America from Middle-East Oil Dependence and Make Money Growing Fuel Yorkshire Press ISBN: 978-0-9707227-4-4.

Tyson, S. (2002) National Renewable Energy Laboratory "Brown Grease Feedstocks for Biodiesel" presentation in collaboration with NRBP 2002. 
USDA, (2006) Statement of Keith Collins Chief Economist, U.S Department of Agriculture Before the U.S. Senate Committee on Environment and Public Works. www.usda.gov.

Watanabe, Y., Noue, J. de la., Hall, D.O., (2004) "Photosynthetic performance of helical tubular photobioreactor incorporating the cyanobacterium spiulina platensis" Biotechnology and Bioengineering 42:2 pp 261-269.

Weissman, J.C., Goebel, R.P. (1987) "Design and analysis of microalgal open pond systems for the purpose of producing fuels: A subcontract report." USDOE. Subcontract No.XK-3-03153-1.

http://www.osti.gov/bridge/product.biblio.jsp?query id=0\&page=0\&osti id =6546458.

Zhang, X., Peterson, C., Reece, D., Haws, R., Möller, G., (1998) "Biodegradability of Biodiesel in the Aquatic Environment." American Society of Agricultural Engineers: 41(5): pp 1423-1430. 


\section{APENDIX A}

\section{Ammonia testing}

\section{Analyses and method description by Adam Feffer (2007) “The Effects of $\mathrm{CO}_{2}$ Addition on Algae Wastewater Treatment"}

Ammonia levels were determined through Experiments I-III using the AmmoniaSelective Electrode Method (APHA 4500- $\mathrm{NH}_{3}$ D.) with some process modifications and minor additions. The specific apparatus used was as follows:

- Hanna Instruments $209 \mathrm{pH}$ Meter and Electrometer

- Orion 95-12 Ammonia-selective electrode

- Oakton $\mathrm{pH} / \mathrm{mV} /{ }^{\circ} \mathrm{C} 11$ Series Meter with EE6 $\mathrm{pH} /$ Temp probe

- Fisher Thermix Model 120 MR Stirrer

Through initial testing before the start of Experiment I, the Orion probe was found to be inconsistent in determining concentrations below $0.5 \mathrm{mg} / \mathrm{L}$ ammonia as $\mathrm{N}$. As a result of this inconsistency at low concentrations, instead of calibrating with decimal variations in ammonia standard from $0.1 \mathrm{mg} / \mathrm{L}$ to $1000 \mathrm{mg} / \mathrm{L}$ ammonia as $\mathrm{N}$, calibration standards used were $1 \mathrm{mg} / \mathrm{L}, 10 \mathrm{mg} / \mathrm{L}, 50 \mathrm{mg} / \mathrm{L}$, and $100 \mathrm{mg} / \mathrm{L}$. Additionally, it was found that the probe yielded more consistent results when, in addition to deionized water rinsing, it was soaked in deionized water for 15-30 seconds after being exposed to concentrations of more than $100 \mathrm{mg} / \mathrm{L}-\mathrm{N}$ or when the probe was moved from a sample with high concentration to a sample with significantly lower concentration.

The Orion 95-12 Electrode manual noted that the probe was subject to $2 \%$ fluctuation in reading per $1^{\circ} \mathrm{C}$ temperature change, therefore it was important that temperature of all samples and standards was recorded. If fluctuation of more than $2^{\circ} \mathrm{C}$ was observed while waiting for a probe to stabilize, then a new trial was conducted. Temperature change among samples and standards was minimized by using a stirrer that does not heat up during use, and also by bringing samples and standards to room temperature before testing. Orion Ammonia pH-adjusting ISA (\#1310-73-2) was used in place of the $\mathrm{NaOH}$ reagent described in APHA 4500- $\mathrm{NH}_{3} \mathrm{D}$. 


\section{APPENDIX B}

\section{Kjeldahl Nitrogen Testing}

\section{Analyses by Kyle Poole and Adam Feffer, method description by Adam Feffer (2007) “The Effects of $\mathrm{CO}_{2}$ Addition on Algae Wastewater Treatment"}

Kjeldahl nitrogen testing was used to determine the levels of organic nitrogen using APHA Method 4500- $\mathrm{N}_{\text {org }}$ Macro-Kjeldahl Method. Ammonia levels were measured by ammonia selective electrode (as described below), so Macro-Kjeldahl Method Step 4b. Ammonia removal was omitted. The remainder of the procedure was conducted in full, and after Kjeldahl nitrogen was determined, ammonia concentration was subtracted to yield organic nitrogen. One slight change in the standard method was to use $0.01-\mathrm{N}$ acid as a titrant for the ammonia titration in Step 4e, instead of the 0.02-N recommended. This lower concentration acid gave greater resolution in determining the end point of titration.

Additionally, a procedure was added in order to rinse the Kjeldahl distillation apparatus with deionized water upon completion of ammonia distillation. While the Kjeldahl flasks were still hot, and burners still turned on, the stoppers of the distillation apparatus were disconnected from the Kjeldahl flasks. Erlenmeyer flasks containing boric acid solution and distilled ammonia were removed, and clean beakers with $150 \mathrm{~mL}$ of deionized water were placed under each distillation tube. Stoppers from the ammonia distillation apparatus were resealed to the Kjeldahl flasks, and burners were turned off. This action created a suction from the flask to the beaker that results in the siphoning of the $150 \mathrm{~mL}$ of deionized water fully through the distillation tube, into the Kjeldahl flask 


\section{APPENDIX C}

\section{Lipid Extraction Data}

\begin{tabular}{|c|c|c|c|c|c|c|c|c|c|c|c|c|c|c|c|}
\hline$\underset{\text { Day pay }}{\text { Sample }}$ & $\begin{array}{l}\text { Sample } \\
\text { Code }\end{array}$ & $\begin{array}{c}\text { Sample } \\
\text { Description }\end{array}$ & $\begin{array}{c}\text { vss } \\
(m g / L)\end{array}$ & $\begin{array}{c}\text { Volume } \\
\text { centrifuged } \\
(m L)\end{array}$ & $\begin{array}{c}\text { B iom ass } \\
(\mathrm{mg})\end{array}$ & $\begin{array}{l}\text { 1st Tare } \\
(\mathrm{g})\end{array}$ & $\begin{array}{c}\text { 1stTare } \\
+ \text { Lipids } \\
(g)\end{array}$ & $\begin{array}{c}\text { 1st Final } \\
\text { Extraction } \\
(m g)\end{array}$ & $\begin{array}{c}2 n d T \text { are } \\
(g)\end{array}$ & $\begin{array}{c}2 n d \text { Tare }+ \\
\text { Lipids }(g)\end{array}$ & $\begin{array}{c}2 n d \text { Final } \\
\text { Extraction } \\
(m g)\end{array}$ & $\begin{array}{c}\text { Total Lipids } \\
(\mathrm{mg})\end{array}$ & Lipids $\%$ & $\begin{array}{c}\text { Lipid } \\
\text { content of } \\
\text { ww (mg/L) }\end{array}$ & $\begin{array}{c}\text { Lipid } \\
\text { Productivity } \\
\text { (mg/L/day }\end{array}$ \\
\hline $\begin{array}{l}3 \\
3 \\
3 \\
3 \\
3 \\
3 \\
3\end{array}$ & $\begin{array}{l}22-1 R 1 \\
22-2 R 1 \\
22-3 R 2 \\
22-4 R 2 \\
22-1 R 3 \\
22-2 R 3\end{array}$ & $\begin{array}{c}10 \% \mathrm{~W} \mathrm{~W} \\
\text { Dilution }\end{array}$ & $\begin{array}{l}280 \\
280 \\
300 \\
300 \\
250 \\
250\end{array}$ & $\begin{array}{l}200 \\
200 \\
200 \\
200 \\
200 \\
200\end{array}$ & $\begin{array}{l}56 \\
56 \\
60 \\
60 \\
50 \\
50\end{array}$ & $\begin{array}{l}1.1071 \\
1.1027 \\
1.1041 \\
1.0817 \\
1.1075 \\
1.1023\end{array}$ & $\begin{array}{l}1.1131 \\
1.1094 \\
1.1104 \\
1.0919 \\
1.1137 \\
1.1083\end{array}$ & $\begin{array}{c}6 \\
6.7 \\
6.3 \\
10.2 \\
6.2 \\
6\end{array}$ & $\begin{array}{l}1.0875 \\
1.0948 \\
1.1011 \\
1.0908 \\
1.0673 \\
1.0856\end{array}$ & $\begin{array}{l}1.0885 \\
1.0956 \\
1.102 \\
1.0933 \\
1.0698 \\
1.0869\end{array}$ & $\begin{array}{c}1 \\
0.8 \\
0.9 \\
2.5 \\
2.5 \\
1.3\end{array}$ & $\begin{array}{c}7 \\
7.5 \\
7.2 \\
12.7 \\
8.7 \\
7.3\end{array}$ & $\begin{array}{l}12.5 \% \\
13.4 \% \\
12.0 \% \\
21.2 \% \\
17.4 \% \\
14.6 \%\end{array}$ & $\begin{array}{l}35.0 \\
37.5 \\
36.0 \\
63.5 \\
43.5 \\
36.5\end{array}$ & $\begin{array}{l}11.7 \\
12.5 \\
12.0 \\
21.2 \\
14.5 \\
12.2\end{array}$ \\
\hline $\begin{array}{l}3 \\
3 \\
3 \\
3 \\
3 \\
3 \\
3\end{array}$ & $\begin{array}{l}22-3 R 4 \\
22-4 R 4 \\
22-1 R 5 \\
22-2 R 5 \\
22-3 R 6 \\
22-4 R 6\end{array}$ & $\begin{array}{c}25 \% \mathrm{w} w \\
\text { Dilution }\end{array}$ & $\begin{array}{l}280 \\
280 \\
270 \\
270 \\
260 \\
260\end{array}$ & $\begin{array}{l}200 \\
200 \\
200 \\
200 \\
200 \\
200\end{array}$ & $\begin{array}{l}56 \\
56 \\
54 \\
54 \\
52 \\
52\end{array}$ & $\begin{array}{l}1.0915 \\
1.0997 \\
1.0861 \\
1.1027 \\
1.0637 \\
1.0922\end{array}$ & $\begin{array}{l}1.0990 \\
1.1055 \\
1.0955 \\
1.1085 \\
1.0696 \\
1.0976\end{array}$ & $\begin{array}{l}7.5 \\
5.8 \\
9.4 \\
5.8 \\
5.9 \\
5.4\end{array}$ & $\begin{array}{l}1.1011 \\
1.0778 \\
1.0743 \\
1.0791 \\
1.0691 \\
1.0947\end{array}$ & $\begin{array}{l}1.1206 \\
1.0795 \\
1.0766 \\
1.0805 \\
1.0699 \\
1.0962\end{array}$ & $\begin{array}{c}19.5 \\
1.7 \\
2.3 \\
1.4 \\
0.8 \\
1.5\end{array}$ & $\begin{array}{c}27 \\
7.5 \\
11.7 \\
7.2 \\
6.7 \\
6.9\end{array}$ & $\begin{array}{l}48.2 \% \\
13.4 \% \\
21.7 \% \\
13.3 \% \\
12.9 \% \\
13.3 \%\end{array}$ & $\begin{array}{c}135.0 \\
37.5 \\
58.5 \\
36.0 \\
33.5 \\
34.5\end{array}$ & $\begin{array}{l}45.0 \\
12.5 \\
19.5 \\
12.0 \\
11.2 \\
11.5\end{array}$ \\
\hline $\begin{array}{l}6 \\
6 \\
6 \\
6 \\
6 \\
6\end{array}$ & $\begin{array}{l}25-1 R 1 \\
25-2 R R 1 \\
25-3 R 2 \\
25-4 R 2 \\
25-1 R 2 \\
25-2 R 3\end{array}$ & $\begin{array}{c}10 \% \mathrm{w} w \\
\text { Dilution }\end{array}$ & $\begin{array}{l}510 \\
510 \\
500 \\
500 \\
450 \\
450\end{array}$ & $\begin{array}{l}200 \\
200 \\
200 \\
200 \\
200 \\
200\end{array}$ & $\begin{array}{l}102 \\
102 \\
100 \\
100 \\
90 \\
90\end{array}$ & $\begin{array}{l}1.0875 \\
1.0995 \\
1.0797 \\
1.1007 \\
1.1052 \\
1.1007\end{array}$ & $\begin{array}{l}1.0944 \\
1.1063 \\
1.0843 \\
1.1168 \\
1.1142 \\
1.1118\end{array}$ & $\begin{array}{c}6.9 \\
6.8 \\
4.6 \\
16.1 \\
9 \\
11.1\end{array}$ & $\begin{array}{l}1.0928 \\
1.1003 \\
1.1197 \\
1.0956 \\
1.0845 \\
1.0927\end{array}$ & $\begin{array}{l}1.0942 \\
1.1017 \\
1.1224 \\
1.101 \\
1.0876 \\
1.0944\end{array}$ & $\begin{array}{l}1.4 \\
1.4 \\
2.7 \\
5.4 \\
3.1 \\
1.7\end{array}$ & $\begin{array}{l}8.3 \\
8.2 \\
7.3 \\
21.5 \\
12.1 \\
12.8\end{array}$ & $\begin{array}{l}8.1 \% \\
8.0 \% \\
7.3 \% \\
21.5 \% \\
13.4 \% \\
14.2 \%\end{array}$ & $\begin{array}{c}41.5 \\
41.0 \\
36.5 \\
107.5 \\
60.5 \\
64.0\end{array}$ & $\begin{array}{l}6.9 \\
6.8 \\
6.1 \\
17.9 \\
10.1 \\
10.7\end{array}$ \\
\hline $\begin{array}{l}6 \\
6 \\
6 \\
6 \\
6 \\
6\end{array}$ & $\begin{array}{l}25-3 R 4 \\
25-4 R 4 \\
25-1 R 5 \\
25-2 R 5 \\
25.3 R 6 \\
25-4 R 6\end{array}$ & $\begin{array}{c}25 \% \mathrm{w} w \\
\text { Dilution }\end{array}$ & $\begin{array}{l}345 \\
345 \\
375 \\
375 \\
370 \\
370\end{array}$ & $\begin{array}{l}200 \\
200 \\
200 \\
200 \\
200 \\
200\end{array}$ & $\begin{array}{l}69 \\
69 \\
75 \\
75 \\
74 \\
74\end{array}$ & $\begin{array}{l}1.0726 \\
1.0890 \\
1.0788 \\
1.0978 \\
1.0658 \\
1.0662\end{array}$ & $\begin{array}{l}1.0902 \\
1.1037 \\
1.0921 \\
1.1113 \\
1.0849 \\
1.0794\end{array}$ & $\begin{array}{l}17.6 \\
14.7 \\
13.3 \\
13.5 \\
19.1 \\
13.2\end{array}$ & $\begin{array}{l}1.0896 \\
1.0998 \\
1.0896 \\
1.09991 \\
1.1087 \\
1.0809\end{array}$ & $\begin{array}{l}1.0945 \\
1.1038 \\
1.101 \\
1.1019 \\
1.1133 \\
1.0874\end{array}$ & $\begin{array}{c}4.9 \\
4 \\
11.4 \\
2.8 \\
4.6 \\
6.5\end{array}$ & $\begin{array}{l}22.5 \\
18.7 \\
24.7 \\
16.3 \\
23.7 \\
19.7\end{array}$ & $\begin{array}{l}32.6 \% \\
27.1 \% \\
32.9 \% \\
21.7 \% \\
32.0 \% \\
26.6 \%\end{array}$ & $\begin{array}{c}112.5 \\
93.5 \\
123.5 \\
81.5 \\
11.5 \\
98.5\end{array}$ & $\begin{array}{l}18.8 \\
15.6 \\
20.6 \\
13.6 \\
19.7 \\
16.4\end{array}$ \\
\hline $\begin{array}{l}9 \\
9 \\
9 \\
9 \\
9 \\
9\end{array}$ & $\begin{array}{c}28-1-\mathrm{R} 1 \\
28-2-\mathrm{R} 1 \mathrm{spk} \\
28-3-\mathrm{R} 2 \\
28-4-\mathrm{R} 2 \\
28-1-\mathrm{R} 3 \\
28-2-\mathrm{R} 3\end{array}$ & $\begin{array}{c}10 \% \mathrm{~W} w \\
\text { Dilution }\end{array}$ & $\begin{array}{l}585 \\
585 \\
485 \\
485 \\
500 \\
500\end{array}$ & $\begin{array}{l}200 \\
200 \\
200 \\
200 \\
200 \\
200\end{array}$ & $\begin{array}{l}117 \\
117 \\
97 \\
97 \\
100 \\
100\end{array}$ & $\begin{array}{l}1.1026 \\
1.0890 \\
1.0999 \\
1.0967 \\
1.0775 \\
1.0954\end{array}$ & $\begin{array}{l}1.1129 \\
1.1143 \\
1.1050 \\
1.1064 \\
1.0832 \\
1.1007\end{array}$ & $\begin{array}{l}10.3 \\
25.3 \\
5.1 \\
9.7 \\
5.7 \\
5.3\end{array}$ & $\begin{array}{l}1.0866 \\
1.0915 \\
1.0831 \\
1.1085 \\
1.0946\end{array}$ & $\begin{array}{l}1.091 \\
1.0938 \\
1.0861 \\
1.1106 \\
1.0967\end{array}$ & $\begin{array}{c}0 \\
4.4 \\
2.3 \\
3 \\
2.1 \\
2.1\end{array}$ & $\begin{array}{l}10.3 \\
29.7 \\
7.4 \\
12.7 \\
7.8 \\
7.4\end{array}$ & $\begin{array}{c}8.8 \% \\
7.6 \% \\
13.1 \% \\
7.8 \% \\
7.4 \%\end{array}$ & $\begin{array}{l}51.5 \\
37.0 \\
63.5 \\
39.0 \\
37.0\end{array}$ & $\begin{array}{l}5.7 \\
0.0 \\
4.1 \\
7.1 \\
4.3 \\
4.1\end{array}$ \\
\hline $\begin{array}{l}9 \\
9 \\
9 \\
9 \\
9 \\
9\end{array}$ & $\begin{array}{c}28-3-R 4 \\
28-4-R 4 \\
28-1-R 5 \\
28-2-R 5 \\
28-3-R 6 \\
28-4-R 6 \text { spk }\end{array}$ & $\begin{array}{c}25 \% w w w \\
D \text { ilution }\end{array}$ & $\begin{array}{l}630 \\
630 \\
610 \\
610 \\
600 \\
600\end{array}$ & $\begin{array}{l}200 \\
200 \\
200 \\
200 \\
200 \\
200\end{array}$ & $\begin{array}{l}126 \\
126 \\
122 \\
122 \\
120 \\
120\end{array}$ & $\begin{array}{l}1.0989 \\
1.0984 \\
1.0753 \\
1.0911 \\
1.1217 \\
1.1061\end{array}$ & $\begin{array}{l}1.1130 \\
1.1109 \\
1.0931 \\
1.1053 \\
1.1391 \\
1.1329\end{array}$ & $\begin{array}{l}14.1 \\
12.5 \\
17.8 \\
14.2 \\
17.4 \\
26.8\end{array}$ & $\begin{array}{l}1.0911 \\
1.0903 \\
1.1065 \\
1.0883 \\
1.0932 \\
1.1076\end{array}$ & $\begin{array}{l}1.0942 \\
1.0944 \\
1.1094 \\
1.0939 \\
1.0966 \\
1.1182\end{array}$ & $\begin{array}{c}3.1 \\
4.1 \\
2.9 \\
5.6 \\
3.4 \\
10.6\end{array}$ & $\begin{array}{l}17.2 \\
16.6 \\
20.7 \\
19.8 \\
20.8 \\
37.4\end{array}$ & $\begin{array}{l}13.7 \% \\
13.2 \% \\
17.0 \% \\
16.2 \% \\
17.3 \%\end{array}$ & $\begin{array}{c}86.0 \\
83.0 \\
103.5 \\
99.0 \\
104.0\end{array}$ & $\begin{array}{c}9.6 \\
9.2 \\
11.5 \\
11.0 \\
11.6\end{array}$ \\
\hline $\begin{array}{l}12 \\
12 \\
12 \\
12 \\
12 \\
12\end{array}$ & $\begin{array}{l}31-1-R 1 \\
31-2-R 1 \\
31-3-R 2 \\
31-4-R 2 \\
31-1-R 3 \\
31-2-R 3\end{array}$ & $\begin{array}{c}10 \% \mathrm{Ww} \\
\text { Dilution }\end{array}$ & $\begin{array}{l}485 \\
485 \\
250 \\
250 \\
320 \\
320\end{array}$ & $\begin{array}{l}200 \\
200 \\
200 \\
200 \\
200 \\
200\end{array}$ & $\begin{array}{l}97 \\
97 \\
50 \\
50 \\
64 \\
64\end{array}$ & $\begin{array}{l}1.0881 \\
1.0957 \\
1.0791 \\
1.0985 \\
1.0940\end{array}$ & $\begin{array}{l}1.0918 \\
1.0988 \\
1.0823 \\
1.1004 \\
1.0973\end{array}$ & $\begin{array}{l}0 \\
3.7 \\
3.1 \\
3.2 \\
1.9 \\
3.3\end{array}$ & $\begin{array}{l}1.1035 \\
1.0880 \\
1.0682 \\
1.0834 \\
1.0965\end{array}$ & $\begin{array}{l}1.1069 \\
1.0896 \\
1.0693 \\
1.084 \\
1.0984\end{array}$ & $\begin{array}{l}3.4 \\
1.6 \\
1.1 \\
0.6 \\
1.9\end{array}$ & $\begin{array}{l}7.1 \\
4.7 \\
4.3 \\
2.5 \\
5.2\end{array}$ & $\begin{array}{l}7.3 \% \\
9.4 \% \\
8.6 \% \\
3.9 \% \\
8.1 \%\end{array}$ & $\begin{array}{l}0.0 \\
35.5 \\
23.5 \\
21.5 \\
12.5 \\
26.0\end{array}$ & $\begin{array}{l}0.0 \\
3.0 \\
2.0 \\
1.8 \\
1.0 \\
2.2\end{array}$ \\
\hline $\begin{array}{l}12 \\
12 \\
12 \\
12 \\
12 \\
12\end{array}$ & $\begin{array}{c}31-3-R 4 \text { spk } \\
31-4-R 4 \\
31-1-R 5 \\
31-2-R 5 \\
31-3-R 6 \\
31-4-R 6\end{array}$ & $\begin{array}{c}25 \% \mathrm{WW} \\
\text { Dilu tion }\end{array}$ & $\begin{array}{l}850 \\
850 \\
835 \\
835 \\
845 \\
845\end{array}$ & $\begin{array}{l}200 \\
200 \\
200 \\
200 \\
200 \\
200\end{array}$ & $\begin{array}{l}170 \\
170 \\
167 \\
167 \\
169 \\
169\end{array}$ & $\begin{array}{l}1.0717 \\
1.0925 \\
1.1154 \\
1.0755 \\
1.0923 \\
1.0677\end{array}$ & $\begin{array}{l}1.0890 \\
1.1052 \\
1.1293 \\
1.0903 \\
1.1010 \\
1.0810\end{array}$ & $\begin{aligned} 17.3 \\
12.7 \\
13.9 \\
14.8 \\
8.7 \\
13.3\end{aligned}$ & $\begin{array}{l}1.1129 \\
1.1083 \\
1.0998 \\
1.0987 \\
1.0824 \\
1.0854\end{array}$ & $\begin{array}{l}1.1214 \\
1.1135 \\
1.1048 \\
1.1026 \\
1.0876 \\
1.0883\end{array}$ & $\begin{array}{l}8.5 \\
5.2 \\
5 \\
3.9 \\
5.2 \\
2.9\end{array}$ & $\begin{array}{l}25.8 \\
17.9 \\
18.9 \\
18.7 \\
13.9 \\
16.2\end{array}$ & $\begin{array}{l}10.5 \% \\
11.3 \% \\
11.2 \% \\
8.2 \% \\
9.6 \%\end{array}$ & $\begin{array}{l}89.5 \\
94.5 \\
93.5 \\
69.5 \\
81.0\end{array}$ & $\begin{array}{l}7.5 \\
7.9 \\
7.8 \\
5.8 \\
6.8\end{array}$ \\
\hline $\begin{array}{l}15 \\
15 \\
15 \\
15\end{array}$ & $\begin{array}{l}3-1-R 4 \\
3-2-R 5 \\
3-3-R 5 \\
3-4-R 6\end{array}$ & $\begin{array}{c}25 \% \text { W W } \\
\text { Dilution }\end{array}$ & $\begin{array}{l}660 \\
690 \\
690 \\
690\end{array}$ & $\begin{array}{l}200 \\
200 \\
200 \\
200\end{array}$ & $\begin{array}{l}132 \\
138 \\
138 \\
138\end{array}$ & $\begin{array}{l}1.0933 \\
1.0909 \\
1.0881 \\
1.0923\end{array}$ & $\begin{array}{l}1.0996 \\
1.0971 \\
1.0959 \\
1.1015\end{array}$ & $\begin{array}{l}6.3 \\
6.2 \\
7.8 \\
9.2\end{array}$ & $\begin{array}{l}1.1003 \\
1.0847 \\
1.0712 \\
1.1022\end{array}$ & $\begin{array}{l}1.1027 \\
1.0887 \\
1.0745 \\
1.107\end{array}$ & $\begin{array}{c}2.4 \\
4 \\
3.3 \\
4.8\end{array}$ & $\begin{array}{c}8.7 \\
10.2 \\
11.1 \\
14\end{array}$ & $\begin{array}{l}6.6 \% \\
7.4 \% \\
8.0 \% \\
10.1 \%\end{array}$ & $\begin{array}{l}43.5 \\
51.0 \\
55.5 \\
70.0\end{array}$ & $\begin{array}{l}2.9 \\
3.4 \\
3.7 \\
4.7\end{array}$ \\
\hline
\end{tabular}

